\title{
Performances musicais distribuídas através de Internet residencial
}

\author{
Marcio Masaki Tomiyoshi \\ DISSERTAÇÃO APRESENTADA \\ AO \\ INSTITUTO DE MATEMÁTICA E ESTATÍSTICA \\ DA \\ UNIVERSIDADE DE SÃO PAULO \\ PARA \\ OBTENÇÃO DO TÍTULO \\ DE \\ MESTRE EM CIÊNCIAS \\ Programa: Ciência da Computação \\ Orientador: Prof. Dr. Marcelo Gomes de Queiroz
}

Durante o desenvolvimento deste trabalho o autor recebeu auxílio financeiro da CNPq 



\title{
Performances musicais distribuídas através de Internet residencial
}

\author{
Esta versão da dissertação contém as correções e alterações sugeridas \\ pela Comissão Julgadora durante a defesa da versão original do trabalho, \\ realizada em 27/05/2013. Uma cópia da versão original está disponível no \\ Instituto de Matemática e Estatística da Universidade de São Paulo.
}

Comissão Julgadora:

- Prof. Dr. Marcelo Gomes de Queiroz (orientador) - IME-USP

- Prof. Dr. Fabio Kon - IME-USP

- Prof. Dr. Fernando Henrique de Oliveira lazzetta - ECA-USP 



\section{Resumo}

\section{Performances musicais distribuídas através de Internet residencial}

A ideia de se permitir que diversos músicos possam interagir remotamente utilizando-se de redes de computadores não é nova, mas nunca se popularizou. O que antes era limitado tecnologicamente devido às condições disponibilizadas por conexões de internet pela linha telefônica, hoje apresenta-se muito mais viável tecnicamente com a massificação da internet de banda larga, seja por cabo ou por tecnologias DSL. Apesar disso, encontrar um ambiente virtual em que a performance musical pareça completamente natural para o músico é uma das maiores dificuldades nesta área.

Embora a latência obtida na conexão entre computadores esteja vinculada principalmente à distância entre os usuários e à qualidade do serviço oferecido pelos provedores de internet, outros aspectos, como a largura de banda, podem ser controlados pelo software. Para lidar com as limitações de largura de banda no acesso à internet disponíveis comercialmente, um método de compactação de áudio eficiente e que alie baixa latência algorítmica com alta qualidade sonora é imprescindível. Para evitar que atrasos muito grandes na transmissão do áudio impossibilitem uma interação musical entre os participantes, uma técnica em que a própria resposta sonora do instrumento seja atrasada localmente torna-se uma alternativa válida na busca de um ambiente para performances musicais via rede.

Esta dissertação busca apresentar uma alternativa flexível e de fácil utilização para que a realização de performances musicais distribuídas por usuários caseiros seja possível, mesmo que estes não tenham acesso a redes dedicadas para tal finalidade.

Palavras-chave: computação musical, performance musical distribuída, transmissão de áudio via rede. 


\section{Abstract}

\section{Network music performance over the residential Internet}

The idea of allowing several musicians to interact remotely using computer networks is not new but it never became popular. What was once technologically limited because of the conditions available through dial up internet connections is now much more technically feasible with the massification of the broadband internet, whether by cable or by DSL technologies. In spite of that, finding a place where the music performance feels completely natural to the musicians is still one of the biggest challenges in this area.

Even though the latency obtained in the connection between computers is mainly linked to the distance between users and to the quality of the service offered by internet providers, others aspects, like the network bandwidth, can be controlled by software. To deal with the limitations on the internet bandwidth commercially available, an efficient audio coding method that has both low algorithmic latency and high sound quality becomes essential. To avoid letting large audio transmission delays make it impossible for players to have a real musical interaction, a technique where the musical instrument's own feedback is locally delayed represents a viable alternative in search of a favorable environment for network music performances.

This project aims to offer a flexible and easy-to-use alternative so that it is possible for home users to be part of network music performances even if they do not have access to networks dedicated to this end.

Keywords: computer music, network music performance, network audio. 


\section{Sumário}

$\begin{array}{ll}\text { Lista de Abreviaturas } & \text { vii }\end{array}$

Lista de Figuras $\quad$ xi

Lista de Tabelas $\quad$ xiii

1 Introdução $\quad 1$

1.1 Trabalhos Relacionados . . . . . . . . . . . . . . . . . . . . . . . . . 1

1.1 .1 Performances Realizadas . . . . . . . . . . . . . . . . . . . . . . . . . . . . . . .

1.1 .2 Softwares para Performance Musical Distribuída . . . . . . . . . . . . . . 4

1.2 Objetivos do Trabalho e Estrutura do Texto . . . . . . . . . . . . . . . . 6

2 Performance Musical Distribuída 9

2.1 Modelos de Performance . . . . . . . . . . . . . . . . . . . . . . . . . . . . . . . . 9

2.2 Redes de Computadores . . . . . . . . . . . . . . . . . . . . . . 13

2.3 Performances em Internet Residencial . . . . . . . . . . . . . . . . . . . . 22

3 Implementação $\quad 27$

3.1 Soluções Alternativas . . . . . . . . . . . . . . . . . . . . . . . . . . . . 27

3.1 .1 SoundJack . . . . . . . . . . . . . . . . . . . 27

3.1 .2 Skype . . . . . . . . . . . . . . . . . . . . . . . . 30

3.1 .3 JackTrip . . . . . . . . . . . . . . . . . . . . . . . 33

3.2 APls de Áudio . . . . . . . . . . . . . . . . . . . . . . . . . . . . . . . . . . 42

3.2 .1 PortAudio . . . . . . . . . . . . . . . . . . . . . . . . . . 42

3.2 .2 RtAudio . . . . . . . . . . . . . . . . . . . . . . . . . 42

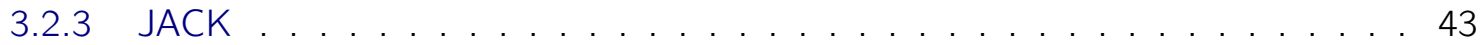

3.3 JackTripMod . . . . . . . . . . . . . . . . . . . . . . . . . . . . . . . 44

3.3 .1 Codificação de Áudio . . . . . . . . . . . . . . . . . . . . . . . . . . . . . . . 44

3.3 .2 Divisão de Pacotes . . . . . . . . . . . . . . . . . . . . . . . . . . . . . . . . 48

3.3.3 Configurações Distintas . . . . . . . . . . . . . . . . . . . . . . . . . . . . . . . . 49

3.3 .4 Modelo de Retorno Atrasado . . . . . . . . . . . . . . . . . . . . . . . . . 50

3.3.5 Tratamento de Buffer . . . . . . . . . . . . . . . . . . . . . . . . 50

3.3.6 Múltiplas Conexões . . . . . . . . . . . . . . . . . . . . . . . . . . . . . 53

3.3 .7 Usabilidade . . . . . . . . . . . . . . . . . . . . . . . . . . . . . 55 
4 Experimentos

4.1 Desenho Experimental . . . . . . . . . . . . . . . . . . . . . . . . . 61

4.2 Resultados . . . . . . . . . . . . . . . . . . . . . . . . . . . . 68

5 Conclusão e Trabalhos Futuros $\quad 75$

$\begin{array}{lll}\text { A CELT } & \mathbf{7 9}\end{array}$

A.1 Introdução . . . . . . . . . . . . . . . . . . . . . . . . . . . . . . . . . . . . . . . . . . . 79

A.2 Divisão em Bandas . . . . . . . . . . . . . . . . . . . . . . . . . . . 79

A.3 Preditor de Longo Prazo . . . . . . . . . . . . . . . . . . . . . . . . . . . . 81

A.4 Detalhes do Espectro . . . . . . . . . . . . . . . . . . . . . . . . . . 82

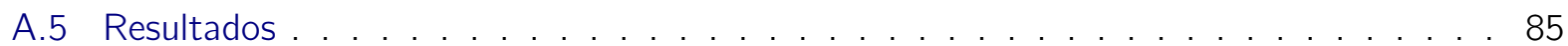

A.6 Conclusão . . . . . . . . . . . . . . . . . . . . . . . . . . 85

Referências Bibliográficas $\quad 89$ 


\title{
Lista de Abreviaturas
}

\author{
AAC Advanced Audio Coding \\ (Codificação Avançada de Áudio) \\ AAC-LD Advanced Audio Coding - Low Delay \\ (Codificação Avançada de Áudio - Baixa Latência) \\ ALSA Advanced Linux Sound Architecture \\ (Arquitetura de Som Avançada para Linux) \\ API Application Programming Interface \\ (Interface de Programação de Aplicações) \\ ASIO Audio Stream Input/Output \\ (Entrada/Saída de Fluxo de Áudio) \\ ATM Asynchronous Transfer Mode \\ (Transferência de Modo Assíncrono) \\ CCRMA Center for Computer Research in Music and Acoustics \\ (Centro para Pesquisa Computacional em Música e Acústica) \\ CD Compact Disc \\ (Disco Compacto) \\ CELP Code-Excited Linear Prediction \\ (Predição Linear Excitada por Códigos) \\ CELT Constrained Energy Lapped Transform \\ (Transformada Sobreposta de Energia Restrita) \\ CERNET2 China Education and Research Network 2 \\ (Rede de Pesquisa e Educação da China 2) \\ DFA Delayed Feedback Approach \\ (Modelo de Retorno Atrasado) \\ DSL Digital Subscriber Line \\ (Linha de Assinante Digital) \\ EPT Ensemble Performance Threshold \\ (Limiar de Performance em Conjunto) \\ FLAC Free Lossless Audio Codec \\ (Codificador/Decodificador de Áudio sem Perdas Livre)
}


FTA Fake Time Approach

(Modelo do Tempo Falso)

Gbps Gigabits por Segundo

GMD Gesellschaft für Mathematik und Datenverarbeitung

(Sociedade de Matemática e Processamento de Dados)

$\mathbf{H z} \quad$ Hertz

IANA Internet Assigned Numbers Authority

(Autoridade dos Números Atribuídos da Internet)

ICE Interactive Connectivity Establishment

(Estabelecimento de Conectividade Interativa)

ICMP Internet Control Message Protocol

(Protocolo de Mensagens de Controle da Internet)

IETF Internet Engineering Task Force

(Força Tarefa de Engenharia da Internet)

IGD Internet Gateway Device

(Dispositivo de Passagem de Internet)

iLBC Internet Low Bitrate Codec

(Codec de Baixa Taxa de Bits para Internet)

$\begin{array}{ll}\text { Inmetro Instituto Nacional de Metrologia, Qualidade e Tecnologia } \\ \text { IP } & \text { Internet Protocol }\end{array}$

(Protocolo de Internet)

iPCM-wb Internet Pulse Code Modulation Wide-Band

(Código por Modulação de Pulso Banda-Larga para Internet)

IQ Info/Query

iSAC Internet Speech Audio Codec

(Codec de Áudio de Voz para Internet)

ISDN Integrated Services Digital Network

(Rede Digital de Serviços Integrados)

ITU-R ITU Radiocommunication Sector

(Setor de Radiocomunicação da ITU)

JACK JACK Audio Connection Kit

(Kit de Conexão de Áudio JACK)

kbps Kilobits por Segundo

LAA Latency Accepting Approach

(Modelo de Aceitação da Latência)

LADSPA Linux Audio Developer's Simple Plugin API

(API de Plugin Simples para Desenvolvedores de Áudio Linux) 


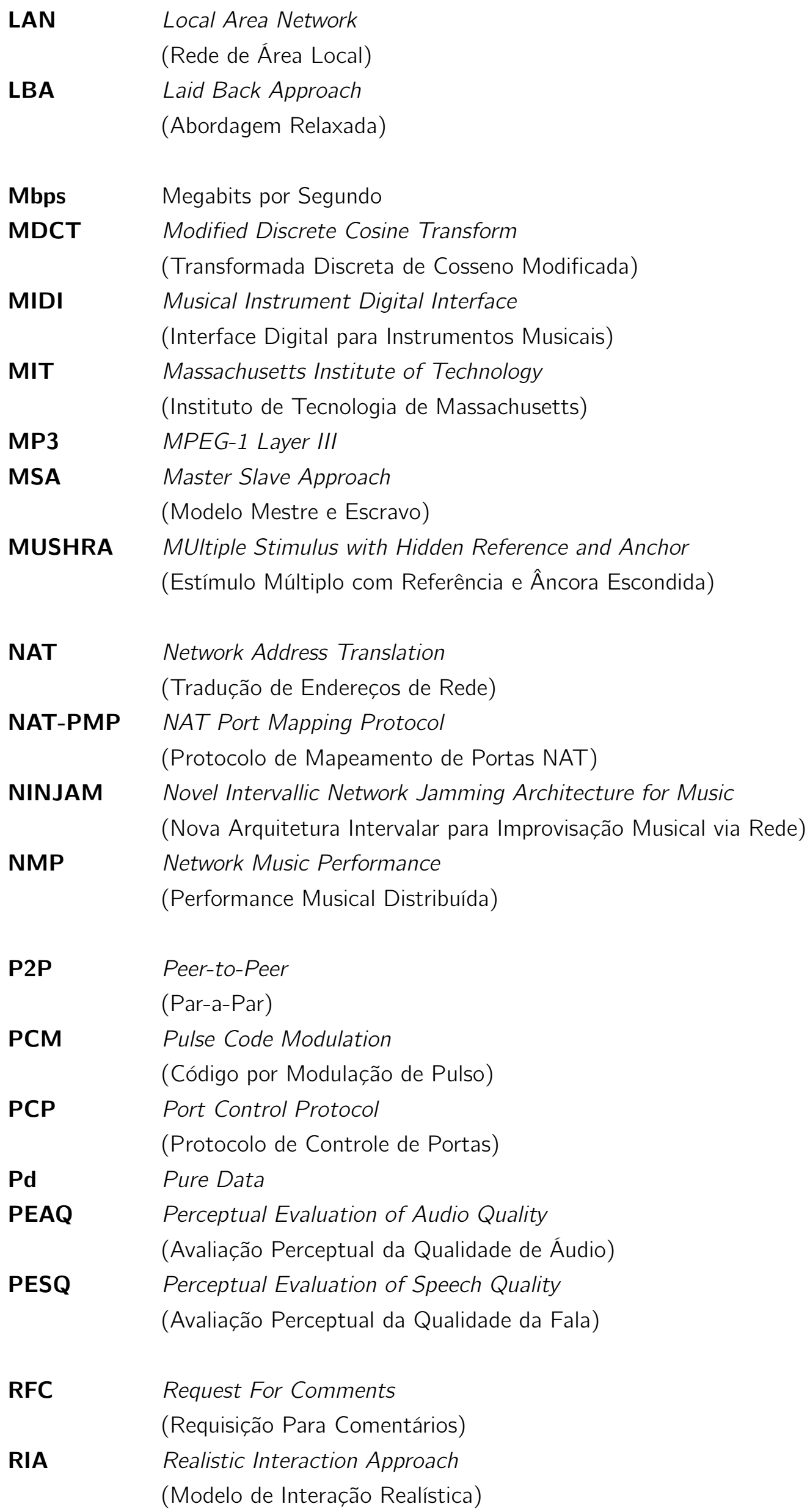


SARC Sonic Arts Research Centre

(Centro de Pesquisa de Artes Sônicas)

SoundWIRE Sound Waves on the Internet from Real-time Echoes

(Ondas Sonoras na Internet a partir de Ecos em Tempo Real)

STUN Session Traversal Utilities for NAT

(Utilitários para Atravessar Sessões para NAT)

SVN Subversion

TCP Transmission Control Protocol

(Protocolo de Transmissão de Controle)

TURN Traversal Using Relays around NAT

(Atravessar NAT Usando Retransmissores)

UDP User Datagram Protocol

(Protocolo de Datagrama de Usuário)

ULD Fraunhofer Ultra Low Delay

(Fraunhofer Ultra Baixa Latência)

UPnP Universal Plug and Play

(Plug and Play Universal)

VolP Voice over IP

(Voz sobre IP)

VST Virtual Studio Technology

(Tecnologia de Estúdio Virtual)

XML Extensible Markup Language

(Linguagem de Marcação Extensível)

XMPP Extensible Messaging and Presence Protocol

(Protocolo de Mensagens e Presença Extensível) 


\section{Lista de Figuras}

2.1 Funcionamento do NINJAM . . . . . . . . . . . . . . . . . . . . 12

2.2 Backbone da Rede Ipề . . . . . . . . . . . . . . . . . . . . . . . . . . . 15

2.3 Topologias de Rede . . . . . . . . . . . . . . . . . . . . . . . . . . . . . . . . . . . . . 17

2.4 Histograma das latências observadas entre São Paulo e Belfast sob diferentes redes . 22

2.5 Comparação entre taxas de download brasileira e mundial . . . . . . . . . . . . . . . . 23

2.6 Comparação entre taxas de upload brasileira e mundial . . . . . . . . . . . . . . . . 23

3.1 Janela principal do SoundJack . . . . . . . . . . . . . . . . . . . . . . . . . . . 28

3.2 Janela de conexão automática do SoundJack . . . . . . . . . . . . . . . . . . . 30

3.3 Janela de conexão manual do SoundJack . . . . . . . . . . . . . . . . . . . . . . 30

3.4 Controle automático de ganho no Skype . . . . . . . . . . . . . . . . . . 31

3.5 Visão geral do JackTrip . . . . . . . . . . . . . . . . . . . . . . . . . . . . . . . . 34

3.6 Diagrama do Karplus-Strong . . . . . . . . . . . . . . . . . . . . . . . . . . . . . 40

3.7 Diagrama do SoundWIRE . . . . . . . . . . . . . . . . . . . . 41

3.8 Estrutura do codificador CELT . . . . . . . . . . . . . . . . . . . . . 46

3.9 Visão geral do JackTripMod . . . . . . . . . . . . . . . . . . . . . . 47

3.10 Arredondamento . . . . . . . . . . . . . . . . . . . . . 52

3.11 Interpolação linear e cúbica . . . . . . . . . . . . . . . . . . . . . . 52

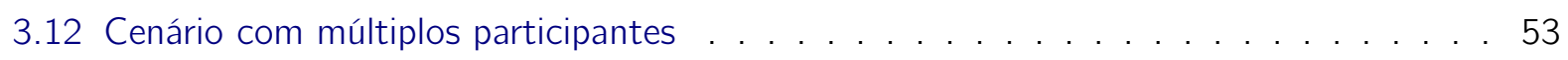

3.13 Interface gráfica do JackTripMod . . . . . . . . . . . . . . . . 56

4.1 Estrutura utilizada para medição da latência do sistema . . . . . . . . . . . . . . . . 65

4.2 Estrutura alternativa para medição da latência do sistema . . . . . . . . . . . . . . 66

4.3 Estrutura para medição da latência da placa de som . . . . . . . . . . . . . . . 67

A.1 Operação das janelas na MDCT . . . . . . . . . . . . . . . . . . . . . . 80

A.2 Regiões críticas do ouvido e a divisão em bandas do CELT . . . . . . . . . . . . . . . 80

A.3 Teste realizado sem o preditor de longo prazo . . . . . . . . . . . . . . . . . . . . . . . . . . . . . . . .

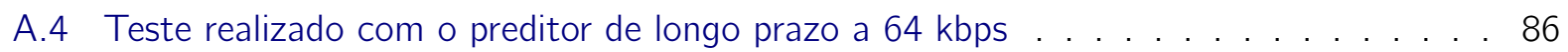




\section{Lista de Tabelas}

2.1 Intervalos de endereços IP para uso privado . . . . . . . . . . . . . . . . . . . 18

2.2 Serviços de Internet oferecidos em São Paulo e Rio de Janeiro (março de 2013) . . . 24

4.1 Versões testadas de cada software . . . . . . . . . . . . . . . . . . . 61

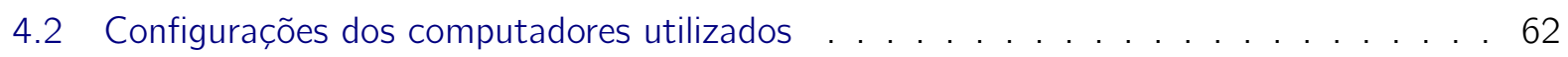

4.3 Escala utilizada no PEAQ . . . . . . . . . . . . . . . . . . . . 63

4.4 Trechos de músicas selecionadas para o experimento utilizando o PEAQ . . . . . . . 64

4.5 Parâmetros utilizados para medição de latência do sistema . . . . . . . . . . . . . . . 66

4.6 Largura de banda utilizada . . . . . . . . . . . . . . . . . . . . . 68

4.7 Comparação de latência entre diversos codificadores . . . . . . . . . . . . . . . 70

4.8 Latências médias obtidas com o JackTrip . . . . . . . . . . . . . . . . . 70

4.9 Latências médias obtidas com o Sound Jack . . . . . . . . . . . . . . . . . 71

4.10 Latências médias obtidas com o Skype . . . . . . . . . . . . . . . . . . . 71

4.11 Latências médias obtidas com o JackTripMod . . . . . . . . . . . . . . . . . . 72

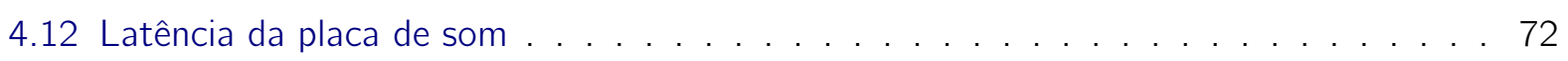

4.13 Latência adicional em relação ao JACK . . . . . . . . . . . . . . . . 73 


\section{Capítulo 1}

\section{Introdução}

A área de performance musical distribuída busca permitir que músicos em diferentes localidades consigam colaborar uns com os outros e seja possível executar uma peça musical em tempo real de forma coesa e da maneira mais natural possível para cada intérprete.

Devido à velocidade de propagação do som no ar, mesmo durante uma performance musical em um palco, existe um certo atraso entre o momento que o som é emitido por um dos intérpretes e é recebido por outro, que responderá adequadamente para que a execução da peça seja musical. Por isso, cada músico sempre está iniciando o movimento para que seu instrumento emita sons de forma antecipada, compensando o atraso do ataque do instrumento fisicamente para que o resultado final esteja sincronizado com o restante dos músicos.

A grande dificuldade de transpor este cenário para um ambiente em que haja uma distância consideravelmente maior entre os intérpretes se dá devido ao tempo envolvido no processo de transmissão de dados em longas distâncias. É de se notar que a latência não tem como ser eliminada completamente já que, estando fisicamente distantes, existe um atraso mínimo para que o som chegue a outro local, mesmo que a transmissão fosse feita na velocidade da luz.

A latência existente na comunicação em redes de computadores é, potencialmente, de uma ordem de magnitude muito superior à existente no cenário em que os músicos estão distantes em um palco. Além disso, ela não é constante, podendo variar com o tempo dependendo da qualidade da infraestrutura envolvida, o que exige que os dados sejam acumulados em um buffer para que o som não seja frequentemente interrompido e acaba por ter como efeito colateral um aumento ainda maior na latência, exigindo que o músico tenha que compensar um atraso muito maior do que o que ele está habitualmente acostumado em performances ao vivo.

Outra dificuldade, especialmente nítida na atual situação da internet nacional, é que a transmissão de áudio descompactado de alta qualidade é inviabilizada devido às baixas taxas de upload disponibilizadas pelos planos mais populares dos provedores de acesso. Além disso, muitos serviços impõem limites de utilização de largura de banda tanto de download como de upload para os usuários, fazendo com que o uso de compactação de dados seja interessante mesmo quando não seja necessária para viabilizar a execução de performances musicais distribuídas.

\subsection{Trabalhos Relacionados}

Diversos estudos já foram realizados na área de performance musical distribuída, desde experiências práticas em que alguma peça tenha sido executada através de estruturas de rede bastante específicas especialmente montadas para tal finalidade, até softwares flexíveis que possibilitem as performances musicais distribuídas através de diferentes abordagens, mas usando a internet comercialmente disponível. A seguir serão listadas algumas das ocasiões em que este tipo de performance foi realizada com uma breve descrição dos cenários encontrados e das técnicas e ferramentas utilizadas. 


\subsubsection{Performances Realizadas}

Em 1996, tentativas iniciais em realizar ensaios distribuídos [KOGC97] foram concretizadas através do uso de uma conexão ATM (Asynchronous Transfer Mode ou Transferência de Modo Assíncrono) de 24 Mbps entre a Universidade de Genebra e o GMD (Gesellschaft für Mathematik und Datenverarbeitung ou Sociedade de Matemática e Processamento de Dados), localizado em Bona. Nesse experimento, seis músicos estavam localizados em Genebra e o condutor da orquestra em Bona. Devido à presença do condutor, além da transmissão de áudio digital, também foi transmitido vídeo, apesar de isso causar uma latência de 80 milissegundos (ms) em comparação aos 20 ms necessários para o áudio. Os resultados deste ensaio foram produtivos, já que a peça ensaiada pôde ser executada posteriormente com sucesso sem que houvesse a necessidade de ensaios presenciais.

Em [Tan99] são descritos alguns experimentos realizados no período de 1994 a 1999. O primeiro deles usava redes ISDN para a realização de videoconferências entre Paris e Nova lorque, Madri e Tóquio, Tóquio e Paris, Tóquio e Nova lorque, Tóquio e Dijon, Barcelona e Amsterdã e Barcelona e Montreal. O segundo usava a própria internet para a transmissão de mensagens do programa Max através de um protocolo que especifica como deve ser realizada a comunicação entre dois usuários Max através de uma rede TCP/IP. Como são transmitidos apenas os dados de controle, toda a síntese do sinal de áudio é realizada localmente por cada um dos clientes conectados. Os concertos realizados ocorreram simultaneamente em Montreal, Estocolmo e Utrecht e, um segundo, em Lisboa, Utrecht e Tóquio. O terceiro experimento foi realizado através da transmissão de áudio em MP3 entre as cidades de Paris, Hamburgo, Viena e Tóquio.

No ano 2000, foi lançado um site chamado Telemusic \#1 [You01], em que a ideia de uma performance musical distribuída era tratada de forma bastante diferente da usual. Um aplicativo em Flash que era executado no navegador do usuário enviava dados a um servidor que estava rodando o Max. O resultado da síntese sonora gerada pelo programa era enviado de volta aos clientes conectados através de um stream de áudio em RealAudio. Assim, diversas pessoas podiam interagir simultaneamente com o aplicativo e criar uma performance interativa em tempo real.

O projeto Ultra-Videoconferencing [WCRM04, UVC] da Universidade McGill de Montreal realizou diversos experimentos transmitindo áudio e vídeo pela rede. Em 2001, um dueto de violino foi apresentado com uma latência de apenas 20 milissegundos, permitindo aos músicos interagirem como se estivessem no mesmo palco, mesmo eles estando em diferentes localizações na cidade de Montreal. Em outubro de 2002 foi realizada uma performance de jazz entre músicos em Montreal e em Stanford utilizando o mesmo sistema. Além disso, o sistema também foi utilizado para transmissão de aulas de música e de medicina remotamente, além da realização de um concerto remoto em que uma orquestra estava se apresentando em Montreal enquanto os engenheiros de gravação estavam em Los Angeles mixando para o público que assistia à performance em um auditório na Universidade do Sul da Califórnia.

Uma performance foi realizada na Universidade de Stanford e na de Pequim em $2008\left[\mathrm{CHI}^{+} 08\right]$. Para a execução da peça foram utilizados três grupos: um conjunto com cerca de 20 notebooks, uma orquestra tradicional e outra de instrumentos típicos da China. As duas primeiras estavam localizadas em Stanford enquanto a última estava em Pequim, a cerca de 9700 quilômetros de distância. Para que o concerto fosse realizado da melhor forma possível, foram utilizadas redes de altíssima velocidade e baixa latência, interligando a Internet2 e a CERNET2 (China Education and Research Network 2), ambas desenvolvidas para uso em pesquisa e educação pelos governos americano e chinês, respectivamente. A largura de banda disponível era de 2,5 a $10 \mathrm{Gbps}$, tornando possível, além do envio de áudio amostrado a $44,1 \mathrm{kHz}$ e 16 bits de resolução, a transmissão de vídeo digital com resolução de 720 pixels por 480 pixels codificado em MPEG-4. Apesar disso, não havia sincronização entre o vídeo e o áudio transmitidos já que o vídeo sofria de uma latência muito maior devido à codificação, totalizando em cerca de um segundo em contraste aos aproximadamente 110 milissegundos necessários para o áudio.

O projeto World Opera (Ópera Mundial) [Wor] planeja ter salas dedicadas para concertos de ópera distribuída, com palcos nas cidades de Troms $\varnothing$, Oslo, Copenhague, Gênova, Nova lorque, São Francisco e Montreal. Diversos artistas localizados nestas cidades realizariam uma performance simultaneamente 
neste palco distribuído pelo mundo. É prevista a transmissão tanto de áudio quanto de vídeo já que a peça se aproveita da presença de um regente. A rede dedicada utilizada possui uma largura de banda máxima de $10 \mathrm{Gbps}$, sendo possível transmitir áudio com qualidade de CD e vídeo comprimido no formato h.264 com resolução de 1920 por 1080 pixels a 30 quadros por segundo. Experimentos para estudo de viabilidade do projeto foram realizados. Por exemplo, dois músicos em Troms $\varnothing$ e um cantor em Stanford fizeram um destes testes em 2007 com uma latência de 123 milissegundos, disponibilizando o áudio gravado durante o ensaio na página oficial do projeto ${ }^{1}$. Em maio de 2011 foi realizada uma demonstração pública da estrutura a ser utilizada através da performance de uma soprano e um barítono, localizados na Califórnia e em Estocolmo respectivamente, e em dezembro do mesmo ano foi realizado o primeiro concerto deste projeto onde foi apresentada a peça "La serva padrona".

Uma peça muito importante para a produção musical através de computadores conectados em rede foi o grupo The Hub [GL98]. Originalmente chamado de The League of Automatic Music Composers, foi formado em 1978 e explorou a ideia de performance musical com o uso de computadores conforme os avanços da tecnologia foram ocorrendo, alterando seus métodos de acordo e adotando protocolos como o MIDI para a troca de mensagens entre os computadores dos participantes a partir de sua criação em 1983, por exemplo.

Outra abordagem interessante foi posta em prática pelo grupo Net vs. Net [CR08]. Ao invés de lutar contra a latência obtida na rede, os integrantes passam a se aproveitar das diferentes percepções causadas pelos atrasos e ausência de sincronia para que as performances passem a sempre considerar os atrasos e falhas no som transmitido como parte do resultado artístico. Apesar disso, em certos momentos ainda é desejada alguma forma de sincronia, como por exemplo, para saber em qual instante a música deve partir para uma seção diferente da que os músicos estavam. Para isso, um servidor controla as latências entre todos os clientes conectados e dispara as mensagens de forma que cada um dos músicos receba a mensagem no mesmo instante de tempo (ou o mais proximamente possível).

No Brasil, o projeto temático MOBILE reúne professores e alunos dos departamentos de Música da Escola de Comunicação e Artes e do departamento de Ciência da Computação do Instituto de Matemática e Estatística, ambos da Universidade de São Paulo, realizando produções musicais com uma forte influência de aspectos tecnológicos. Dentre as atividades desenvolvidas pelo projeto, foram realizadas performances musicais distribuídas entre São Paulo e Belfast em junho de 2011 e em março de 2012, contendo peças compostas especialmente para o ambiente de redes computacionais [Net11, Net12, Coe11, Coe12].

Em maio de 2012, para realizar apresentações em São Paulo, os ensaios entre a Orquestra Sinfônica Alemã de Berlim e a Orquestra Sinfônica Jovem do Estado foram feitos através do Skype devido à falta de tempo hábil para a realização de ensaios presenciais [Sam12]. Em outra ocasião, a mesma ferramenta foi utilizada para uma apresentação conjunta de um grupo de rap e uma banda de rock, cada uma em diferentes espaços de São Carlos [RT12].

No evento "Desafios da Arte em Rede - I Rodada em Cultura, Arte, Tecnociência e Inovação" foi apresentada a obra "Frágil" [Sil12], fazendo a transmissão de áudio e vídeo em rede de Fortaleza para o Rio de Janeiro. A performance baseou-se na integração de diversos instrumentos musicais, utilizando tanto instrumentos acústicos como a escaleta até softwares como o Pd (Pure Data) ${ }^{2}$ para sintetizar sons a partir da informação proveniente de controladores MIDI e de um sistema ligado a um Arduino ${ }^{3}$ que variava conforme a respiração de um dançarino.

Ainda é possível encontrar outras iniciativas para a realização de performances musicais em que os participantes estejam fisicamente distantes, utilizando meios de comunicação que não estejam diretamente relacionados a redes de computadores como transmissões usando telefones, como o já citado experimento através de redes ISDN realizado por A. Tanaka [Tan99], ou por transmissões via

\footnotetext{
${ }^{1}$ http://ccrma.stanford.edu/groups/soundwire/recordings/ - Acessado em novembro de 2012.

${ }^{2}$ Ambiente de programação gráfica para processamento de áudio e vídeo em tempo real. (http://puredata.info/ Acessado em dezembro de 2012).

${ }^{3}$ Plataforma aberta e de baixo custo para a criação de projetos de eletrônica (http://www.arduino.cc/ - Acessado em dezembro de 2012).
} 
satélite, como feito durante a cerimônia de abertura dos Jogos Olímpicos de Inverno de 1998 em Nagano [Oza12].

\subsubsection{Softwares para Performance Musical Distribuída}

Além das performances musicais descritas, também podemos citar diversos sistemas já desenvolvidos que podem ser usados para a prática de performances musicais distribuídas. Os softwares JackTrip, SoundJack e Skype serão discutidos com mais detalhes no capítulo 3 pois tiveram maior impacto no trabalho desenvolvido em comparação a outros aplicativos mencionados nesta listagem, já que possuíam características que iam de encontro ao que era de interesse para a implementação do projeto, servindo como critério de comparação durante a realização dos experimentos. As páginas de cada projeto citado nesta seção foram acessadas em dezembro de 2012.

\section{JackTrip (http://code.google.com/p/jacktrip/)}

Desenvolvido no CCRMA (Center for Computer Research in Music and Acoustics) por Juan-Pablo Cáceres, o JackTrip se propõe a obter a menor latência possível entre as partes conectadas pela rede. Para isso, utiliza-se de áudio sem compactação, necessitando de grande largura de banda disponível para que a performance possa ocorrer com alta qualidade e sem interrupções. Conecta-se ao servidor de áudio JACK (JACK Audio Connection Kit ou Kit de Conexão de Áudio JACK) ${ }^{4}$ ou à placa de som do computador diretamente através da biblioteca RtAudio. Também é possível o seu uso com um dispositivo proprietário chamado jamLink ${ }^{5}$. As conexões entre os usuários são realizadas de forma P2P (Peer-to-Peer ou Par-a-Par).

\section{SoundJack (http://www.soundjack.eu/)}

Criado por Alexander Carôt para sua tese de doutorado [Car09], também busca a menor latência possível entre os participantes, porém dispõe de opções para compactação do áudio exigindo um menor uso de largura de banda em troca de uma latência maior na transmissão do som. Originalmente utilizava o JACK para acessar a placa de som, mas atualmente utiliza a biblioteca PortAudio. Outra característica importante do Sound Jack é que cada músico tem a possibilidade de obter a resposta de seu instrumento atrasada em relação ao normal para que exista uma sincronia entre o que o usuário escuta de seu próprio instrumento e o que está sendo recebido pela rede. Apesar disso, as opções para compactação são limitadas a parâmetros pré-definidos e a granularidade dos atrasos locais disponíveis depende do tamanho do bloco de áudio utilizado. Associando estes fatores à impossibilidade do acesso ao código fonte do programa, obtemos uma ferramenta muito menos flexível do que seria possível.

\section{Skype (http://www.skype.com/)}

Sistema desenvolvido para comunicação do tipo VolP (Voz sobre IP) através de conexões P2P. Atualmente pertence à Microsoft, mas possui clientes para os três principais sistemas operacionais (Windows, Mac OS X e Linux). Apesar de possuir características que levem em consideração a transmissão de voz e não o seu uso em performances musicais distribuídas, em certas ocasiões ainda é utilizado para tal, muito provavelmente devido à sua grande popularidade, já que outros sistemas de VolP não são mencionados com a mesma frequência.

\section{eJamming (http://www.ejamming.com/)}

É uma solução proprietária que exige o pagamento de mensalidades. Funciona de forma semelhante ao JackTrip e SoundJack, porém também permite o envio de mensagens MIDI além do sinal de áudio. Até quatro músicos podem se conectar em uma sessão virtual, de forma $\mathrm{P} 2 \mathrm{P}$ e, além de poderem

\footnotetext{
${ }^{4}$ http://jackaudio.org/

${ }^{5}$ http://www.musicianlink.com/
} 
fazer uma jam session também é possível realizar gravações, como se estivessem em um estúdio digital distribuído. Assim como o SoundJack, permite que o músico atrase localmente o som de seu próprio instrumento para aumentar a sincronia entre as partes.

\section{netjack}

O netjack [CHW09] é um driver incluso nas distribuições JACK permitindo que dois computadores se conectem mantendo sincronia entre eles. O foco do software está na transmissão de áudio de uma máquina escrava para uma mestre. Enquanto a primeira inicia um servidor JACK utilizando o driver netjack, a segunda é aberta com um driver de áudio comum, como o ALSA (Advanced Linux Sound Architecture ou Arquitetura de Som Avançada para Linux). Assim, a máquina escrava não possui acesso à placa de som inicialmente: para a sua utilização em performances musicais distribuídas, é necessário então utilizar um programa como o alsa_in, tornando o netjack uma opção viável apenas para sistemas Linux.

\section{Ilcon (http://sourceforge.net/projects/Ilcon/)}

Alternativa ao Sound Jack e ao JackTrip, é baseado no modelo cliente-servidor e permite o envio de áudio pela rede somente com compactação. Conecta-se ao JACK na versão Linux, mas se aproveita apenas dos drivers ASIO (Audio Stream Input/Output ou Entrada/Saída de Fluxo de Áudio) em sistemas Windows, não havendo a necessidade de se ter o JACK instalado. Uma característica da estrutura escolhida para o programa é que todos os clientes enviam o seu áudio para o servidor e este mixa todos os sons recebidos ao devolver o áudio, economizando banda, mas afetando a qualidade sonora, já que o processamento é feito em um sinal compactado com perdas.

\section{NINJAM (http://www.ninjam.com/)}

Utiliza-se de uma estratégia bastante diferente, aproveitando-se das repetições muitas vezes utilizadas em certos estilos de música, como, por exemplo, o blues de 12 compassos, e, de forma semelhante ao grupo Net vs. Net, não trava uma batalha com a latência. Ao invés disso, cada um dos usuários executa sua parte em cima de partes anteriormente gravadas pelos outros participantes. A performance é dividida em uma quantidade pré-definida de compassos, o programa grava esta quantidade de compassos e transmite para todos os participantes. Quando um cliente recebe o áudio de todos os outros integrantes, o programa inicia a sua execução e faz a mixagem em tempo real com o que o usuário estiver tocando. Este modelo vale para todos os clientes conectados ao servidor principal, não possibilitando conexões P2P. Por ter limites muito mais tolerantes à latência, o áudio transmitido é compactado no formato Vorbis.

\section{netpd (http://www.netpd.org/)}

É um programa que torna possível que diversos usuários interajam simultaneamente em um mesmo patch do Pd. Um servidor é aberto e cada cliente conectado envia mensagens que serão reenviadas para todos os outros. Apenas mensagens de controle são trocadas, não havendo envio de áudio digitalizado, diminuindo as exigências de largura de banda. O netpd garante que todos os usuários estarão utilizando os mesmos patches e todos os eventos produzidos também serão recebidos por todos. Dadas estas características, o foco de sua aplicação está na performance distribuída sem troca de sinais de áudio.

\section{netsend e netsend}

São externals ${ }^{6}$ de $\mathrm{Pd}$ que permitem o envio de mensagens pela rede. O primeiro possibilita apenas a transmissão de sinais de controle, enquanto o segundo permite que sinais de áudio também trafeguem pela rede. Ao contrário do netpd, nenhuma garantia de sincronização entre estados e eventos é dada

\footnotetext{
${ }^{6}$ Um external é um objeto que não faz parte da distribuição do Pd, sendo carregada em tempo de execução.
} 
pelo netsend. Dependendo de como for configurado o patch no Pd, a estrutura da rede poderá ser P2P ou servidor-cliente. O áudio é enviado sem nenhum tipo de compactação. O netsend está disponível na distribuição oficial do $\mathrm{Pd}$, enquanto o netsend está disponível em seu site oficial ${ }^{7}$. Uma versão com algumas correções chamada de netsend $\sim$ SD pode ser localizada em sua página oficial ${ }^{8}$.

\section{JAM with Chrome (http://www.jamwithchrome.com)}

Em novembro de 2012, a Google lançou um website para demonstrar e promover as capacidades multimídia do navegador Chrome de sua autoria. Esta página utiliza diversas tecnologias recentes para o desenvolvimento web e permite que até quatro pessoas participem de uma jam através do próprio navegador, sem a necessidade de instalação de nenhum software adicional. Devido às limitações impostas pela tecnologia e pela estrutura escolhida, apenas mensagens são trocadas entre os participantes e o servidor, sintetizando o áudio a ser reproduzido localmente no computador de cada usuário e sendo impossível transmitir som gerado por instrumentos conectados diretamente à placa de som.

\subsection{Objetivos do Trabalho e Estrutura do Texto}

O objetivo do trabalho é, a partir de um estudo dos vários aspectos que formam a área de performance musical distribuída, implementar uma solução em software chamada JackTripMod que encontre um bom equilíbrio entre estas variáveis, fazendo com que latência, largura de banda e o conforto para o intérprete permitam que performances musicais distribuídas sejam realizadas não somente em ambientes acadêmicos, mas também por usuários caseiros da melhor forma possível dadas as diversas limitações encontradas neste caso já que estes não possuem acesso a infraestruturas dedicadas para este tipo de tarefa.

Assim, no capítulo 2 serão discutidos conceitos relacionados às performances musicais distribuídas, reunindo a contribuição de diversos autores sobre a área. Serão expostos os diversos modelos possíveis para a execução de performances musicais distribuídas, as relações existentes entre latência, largura de banda e jitter, aspectos técnicos de redes de computadores como os protocolos e topologias possíveis de serem utilizados, além de técnicas para melhorar a conectividade entre computadores através da Internet e experimentos realizados para caracterizar as diferenças entre a estrutura de rede acessível através de ambientes acadêmicos e residencias. A partir destes conceitos torna-se possível prover a sustentação teórica necessária para que o escopo do projeto do JackTripMod seja bem definido e realizado de forma adequada.

No capítulo 3 são apresentadas as funcionalidades acrescidas ao JackTrip que resultaram no JackTripMod e um estudo aprofundado dos aplicativos Skype, Sound Jack e JackTrip, frequentemente utilizados em performances musicais distribuídas, que, através de um entendimento das semelhanças e diferenças entre eles, contribuíram com mais informações para a implementação das modificações necessárias ao programa JackTrip [CC10], dando origem ao JackTripMod, que, dentre suas novas funcionalidades, podemos destacar a adição da possibilidade de que seja realizada uma comunicação de áudio compactado através de uma rede de computadores com maior sincronia entre os músicos participantes.

No caso com sincronia, o áudio que for gravado em um determinado instante de tempo por cada computador deverá ser reproduzido simultaneamente para cada usuário. Para isso, algoritmos de sincronização baseados nos utilizados para sincronia de relógios de computadores em rede serão utilizados.

Para diminuir o uso de largura de banda necessário para a realização performances musicais distribuídas seria interessante se aproveitar dos diversos padrões de compactação de alta qualidade existentes atualmente, como o Vorbis e o MP3, por exemplo. Porém, isto não é o ideal devido às altas latências algorítmicas introduzidas por tais codificadores. A alternativa proposta aqui é a

\footnotetext{
${ }^{7}$ http://www.nullmedium.de/dev/netsend $\sim /$

${ }^{8}$ http://www.remu.fr/sound-delta/netsend $\sim / ? p=22$
} 
utilização de um codificador de baixa latência chamado CELT (Constrained Energy Lapped Transform ou Transformada Sobreposta de Energia Restrita). Seu funcionamento é detalhado no apêndice A.

Assim, como principal resultado deste trabalho, é disponibilizado o software JackTripMod permitindo que usuários caseiros possam realizar performances musicais distribuídas com alta qualidade de áudio e baixa latência. O programa JackTrip foi adaptado para possibilitar a compactação do áudio com o codificador CELT e também permitir que o áudio local seja atrasado para que esteja sincronizado com o áudio adquirido pela rede, no modelo conhecido como Delayed Feedback Approach (discutido com mais detalhes na seção 2.1), ambas características não disponíveis em sua versão atual.

Alguns dos programas citados na seção 1.1.2 dispõem de opções de compactação de áudio, mas apenas o eJamming, o Sound Jack e o netjack possibilitam o atraso do áudio local. Porém, o primeiro trata-se de uma alternativa comercial, exigindo o pagamento de mensalidades pelo usuário. Já o segundo, apesar de ser gratuito, não possui o código aberto, além de permitir menor flexibilidade de configuração em comparação ao que foi implementado neste trabalho. O terceiro é o único deles que é um software livre, porém a sua utilização para performances musicais distribuídas é restrita a sistemas operacionais baseados no padrão ALSA. O JackTrip é um software de código aberto disponível para vários sistemas operacionais, baseado na licença MIT e poderá ser oferecido como uma alternativa a eles com as devidas modificações.

Os experimentos conduzidos com diversos softwares também serão de grande importância para avaliar o quanto as alterações realizadas influenciaram nas medidas de latência obtidas e também para analisar a diferença na qualidade do áudio com e sem compactação. Os resultados obtidos e as metodologias empregadas estão no capítulo 4.

O capítulo 5 expõe as considerações finais do trabalho e as direções que podem ser tomadas futuramente com ele. 


\section{Capítulo 2}

\section{Performance Musical Distribuída}

Desde a década de 1990 até os dias atuais, muitas experiências foram realizadas na tentativa de possibilitar que performances musicais fossem concretizadas com músicos fisicamente distantes uns dos outros. Porém, diversas dificuldades impediram que estes experimentos fossem considerados satisfatórios, especialmente em ambientes caseiros. Este ramo da computação musical foi chamado de Performance Musical Distribuída (em inglês, Network Music Performance).

Nos anos 90, as conexões com a Internet eram realizadas através da linha telefônica, trazendo consigo todas as limitações que este tipo de acesso causava. A latência obtida era na casa das centenas de milissegundos, mesmo para curtas distâncias, dificultando (e até impossibilitando) qualquer tipo de interação em tempo real, fosse ela apenas uma videoconferência ou algo que exigisse latências muito mais baixas como os jogos online com múltiplos jogadores e as performances musicais distribuídas.

Além disso, a maior velocidade alcançada com a Internet discada foi de apenas 56 kbps de download ou upload, insuficientes para a transmissão de áudio digital de alta qualidade, já que arquivos codificados com qualidade de CD atingem uma taxa de bits de $1411 \mathrm{kbps}$ (mais detalhes na seção 2.2). Mesmo que fosse realizado algum tipo de compactação, codificadores extremamente eficientes como o MP3 ainda exigiam uma taxa de bits de cerca de $128 \mathrm{kbps}$ para se obter alta qualidade e nem todos os computadores da época tinham capacidade de processamento suficiente para realizar a tarefa de compactação e descompactação em tempo real, o que impossibilitava o uso desse tipo de técnica.

Com a popularização da banda larga, diversos destes problemas enfrentados foram minimizados, apesar de não completamente eliminados. A latência obtida baixou para as dezenas de milissegundos, viabilizando diversas novas possibilidades para o uso da Internet. A largura de banda teve um aumento bastante considerável, porém as taxas de upload e download passaram a ser assimétricas, isto é, o usuário não necessariamente possui a mesma velocidade para fazer upload de arquivos do que para baixar, sendo esta última normalmente bastante superior. Com isso, numa aplicação como as performances musicais distribuídas, que necessitam tanto de altas taxas de download (para receber o áudio vindo de outro músico) quanto de upload (para enviar o áudio), esta menor velocidade para envio pode se tornar uma limitação dependendo do cenário a ser considerado.

No entanto, com os diversos avanços tecnológicos, tanto na área de redes quanto na capacidade de processamento dos computadores pessoais, a situação tornou muito mais promissora, de certa forma viabilizando a ideia de serem realizadas performances musicais mesmo com os músicos estando distantes uns dos outros, sem a necessidade de uma estrutura especialmente projetada para tal finalidade. Para lidar com as limitações, diferentes modelos foram propostos por Alexander Carôt em sua tese de doutorado [CW07, RCR07, CW08, Car09, Car10], como será visto na seção seguinte.

\subsection{Modelos de Performance}

\section{Modelo de Interação Realística}

Imagine que dois músicos estejam interagindo em um palco normal. Dadas as dimensões do palco, há certa distância entre eles e, considerando a velocidade do som e sua transmissão no ar, podemos 
considerar que cada um deles não reage instantaneamente à emissão de um som vindo do parceiro, mas sim no instante em que o som atinge seu ouvido ${ }^{1}$. Supondo que eles estejam distantes 5 metros um do outro e considerando que a velocidade do som seja de $340 \mathrm{~m} / \mathrm{s}$, temos que o som leva cerca de 14 milissegundos para alcançar o ouvido do músico que precisa interagir sincronizadamente com o som emitido.

Transportando este cenário para as performances musicais distribuídas, precisaríamos que a transmissão de áudio de uma ponta à outra estivesse próxima dos valores obtidos no palco, os cerca de $14 \mathrm{~ms}$ calculados anteriormente, por exemplo. Se isso for possível, temos o cenário ideal para que os músicos se sintam confortáveis durante a execução da peça musical. Esse modelo é chamado de Modelo de Interação Realística (Realistic Interaction Approach), dada à sua proximidade com o modelo real de performances musicais e consiste basicamente em tentar minimizar a latência introduzida pela captura do som pelo computador e sua transmissão pela rede. Estudos realizados [SC02] indicam que a maior latência possível para que ainda seja viável a realização de performances musicais é de cerca de 25 ms, valor que foi denominado de Limiar de Performance em Conjunto (Ensemble Performance Threshold).

Assim, aplicar este modelo nem sempre é possível já que a transmissão dos dados de áudio depende da distância: quanto mais longe os músicos estão localizados, maior será a latência. Se pensarmos no caso limite, em que as interfaces de áudio e rede do computador não introduzam latência nenhuma, estando o músico limitado apenas pela latência de transmissão, podemos perceber que, mesmo se o envio de dados fosse realizado à velocidade da luz, a latência alcançaria um valor superior aos 25 ms para uma distância de apenas 7500 km, tornando impraticável a utilização deste modelo em tais distâncias.

Para esses casos em que não é possível obter uma latência abaixo de tal limiar foram criados outros modelos, menos confortáveis do ponto de vista do músico, mas que com a prática e ensaios ajudam a transformar as performances musicais distribuídas em realidade.

\section{Modelo Mestre e Escravo}

Se ainda estivermos tentando minimizar a latência entre os dois músicos distantes um do outro, mas o valor dela acabe por superar o limiar de performance em conjunto, o esperado seria que a realização de uma performance musical fosse impossibilitada. Porém, uma solução para este caso, viável para certos estilos musicais, é fazer com que um dos lados se torne o mestre e o outro o escravo, no que é conhecido como Modelo Mestre e Escravo (Master Slave Approach).

Neste modelo, o mestre passa a executar a sua parte sem se importar com a resposta que o escravo envia. Por exemplo, em uma dupla de bateria e guitarra de um conjunto de rock, o baterista poderia assumir o papel de mestre e passar a ser uma espécie de metrônomo. O guitarrista ao receber o áudio em seu computador passaria a tocar sincronizadamente com a parte do baterista e, no papel de escravo, para ele a performance soaria perfeita. O baterista, contudo, só ouviria as partes da guitarra fora de sincronia com o que ele estava tocando, devido ao atraso provocado pela latência da rede ser maior que os 25 ms sugeridos pelo limiar de performance em conjunto. Por causa disso, o baterista passa a ignorar a resposta que a guitarra está providenciando para ele e mantém o seu ritmo, independentemente do que a guitarra estiver fazendo. Fica claro que neste modelo ocorre uma falta de conectividade entre os músicos. Para o baterista é como se ele estivesse tocando sozinho, sem que haja uma resposta adequada ao que estiver sendo executado, enquanto o guitarrista ainda tem uma parcela de ligação com as partes da bateria e pode reagir à elas, mas não pode influenciá-las. Como resultado dessa dessincronia entre o mestre e o escravo e a falta de ligação entre eles, torna-se impossível a realização de partes uníssonas, já que estas soariam como tal apenas para o escravo.

\footnotetext{
${ }^{1}$ Estamos propositalmente desconsiderando interações não-sonoras, tais como comunicação gestual ou visual.
} 


\section{Abordagem Relaxada}

Quando a latência supera o limiar de performance em conjunto mas mantém-se próxima dos $50 \mathrm{~ms}$, torna-se possível interpretar a relação entre os músicos de forma que o solista esteja intencionalmente tocando ligeiramente fora do pulso, uma forma de expressão artística utilizada em gêneros como o jazz. Quando isto ocorre, o modelo é denominado Abordagem Relaxada (Laid Back Approach).

\section{Modelo de Aceitação da Latência}

Outra forma de se lidar com latências superiores ao limiar de performance em conjunto é caracterizada no modelo denominado Modelo de Aceitação da Latência (Latency Accepting Approach). Como o nome sugere, neste tipo de performance, os músicos param de lutar contra a latência e aceitam ela como parte da performance, de forma análoga à aceitação da acústica de cada sala. É o caso do grupo Net vs. Net [CR08], que cria e executa peças em que não há uma necessidade estrita de sincronia entre as partes, fazendo com que o resultado artístico de cada performance dependa também das condições da rede que está sendo utilizada pelos músicos. Artefatos sonoros causados por perdas de pacotes também acabam sendo levados em consideração neste caso, claramente afetando a performance e o resultado final. O interessante desta abordagem é que ela é totalmente dependente da existência da latência e, possivelmente, se não fosse o desejo da realização das performances musicais distribuídas, este estilo musical mais solto nunca teria sido criado.

\section{Modelo de Retorno Atrasado}

Os modelos a seguir tomam uma abordagem bastante diferente das descritas até agora. No Modelo de Retorno Atrasado (Delayed Feedback Approach), ainda buscamos uma minimização da latência entre os computadores, mas fazemos com que o sinal do instrumento local seja atrasado com a finalidade de que os sons tocados ao mesmo tempo em lugares distintos sejam reproduzidos simultaneamente em ambos os computadores. Por exemplo, supondo que o sinal capturado em um dos computadores demore cerca de 80 ms para ser ouvido na outra ponta da conexão, fazemos com que a resposta do sinal local também seja atrasado em $80 \mathrm{~ms}$, assim o som será executado ao mesmo tempo (ou o mais próximo disso possível) nas duas localidades. Fica claro que neste tipo de abordagem a resposta do instrumento do músico se torna bastante diferente da que é usualmente ouvida por ele.

Em um instrumento acústico como, por exemplo, o violão, a distância entre o local que o som é emitido e o ouvido do músico é muito pequena, digamos que seja algo em torno de 0,5 metro. Assim, o som normalmente leva cerca de 1,5 milissegundo para alcançar o ouvido do instrumentista, valor muito inferior aos $80 \mathrm{~ms}$ do atraso da resposta. Porém, por menos natural que seja esse atraso artificial introduzido pelo modelo, é possível ao ser humano se adaptar a esse ataque mais demorado, já que alguns instrumentos como o órgão e certos sintetizadores clássicos possuem ataques bastante lentos, e, obviamente, existem músicos adaptados a esses níveis de atraso na resposta. Assim, com alguma carga de prática e ensaios é esperado que mesmo uma peça musical tradicional possa ser corretamente executada neste modelo.

Um outro problema desta abordagem é que, dependendo do instrumento, o retorno natural dele pode interferir na resposta atrasada introduzida pelo modelo, dificultando a percepção do músico de que é necessário se antecipar ligeiramente para compensar os atrasos induzidos. Isto não é um problema para instrumentos elétricos como a guitarra, mas pode se tornar uma grande dificuldade para instrumentos acústicos em que não é possível isolar o som direto, como o de uma bateria, uma flauta ou até mesmo da voz humana.

Em performances com grandes grupos de músicos, é importante notar que, por todos deverem estar sincronizados no modelo de retorno atrasado, aquele com a maior latência de rede fará com que todos os outros sofram com as consequências disso, atrasando seus respectivos sinais de acordo com a maior latência. Em um caso extremo, se todos os músicos tiverem uma latência de 30 milissegundos, excetuando um que esteja mais distante e possua uma latência de $100 \mathrm{~ms}$, todos acabarão com a resposta do áudio local atrasada em 100 ms. 


\section{Modelo do Tempo Falso}

Por último, temos o modelo chamado de Modelo do Tempo Falso (Fake Time Approach). Bastante peculiar, este é o modelo implementado pelo software NINJAM, em que, como no modelo de aceitação da latência não há uma batalha contra a mesma, no sentido de minimizá-la. Ao contrário, o modelo do tempo falso utiliza-se de uma técnica bastante diferente em que a interação de cada um dos músicos se dá com um compasso anteriormente tocado pelos músicos restantes. Assim, o que o programa implementa é um atraso muito maior do que aquele ocasionado pela captura do áudio e transmissão pela rede, aumentando intencionalmente a latência e fazendo ela ser medida em compassos musicais ao invés de milissegundos, indo na contramão do procedimento usual. Os sons recebidos só serão reproduzidos em um compasso futuro, então não é preciso correr contra o tempo para que o áudio seja compactado, transmitido e reproduzido, abrindo a possibilidade de se utilizar codificadores que possuem alta latência algorítmica como o Vorbis para manter uma alta qualidade sonora.

Alguns estilos de música são baseados em padrões que se repetem periodicamente ao longo do tempo, e nesses casos esse tipo de abordagem pode funcionar bem, já que é possível, por exemplo, que o contrabaixo e a bateria se mantenham constantemente sincronizados à batida enquanto um instrumento solo improvisa em cima da base, que teria uma estrutura de repetição já conhecida e bem definida. Porém, fica claro que a ligação entre os músicos participantes deste tipo de jam session é fraca e impossibilita diversos tipos de interação musical, como tocar uma passagem em uníssono. Em particular, como será exemplificado a seguir, cada participante da jam session ouve uma versão diferente da música tocada.

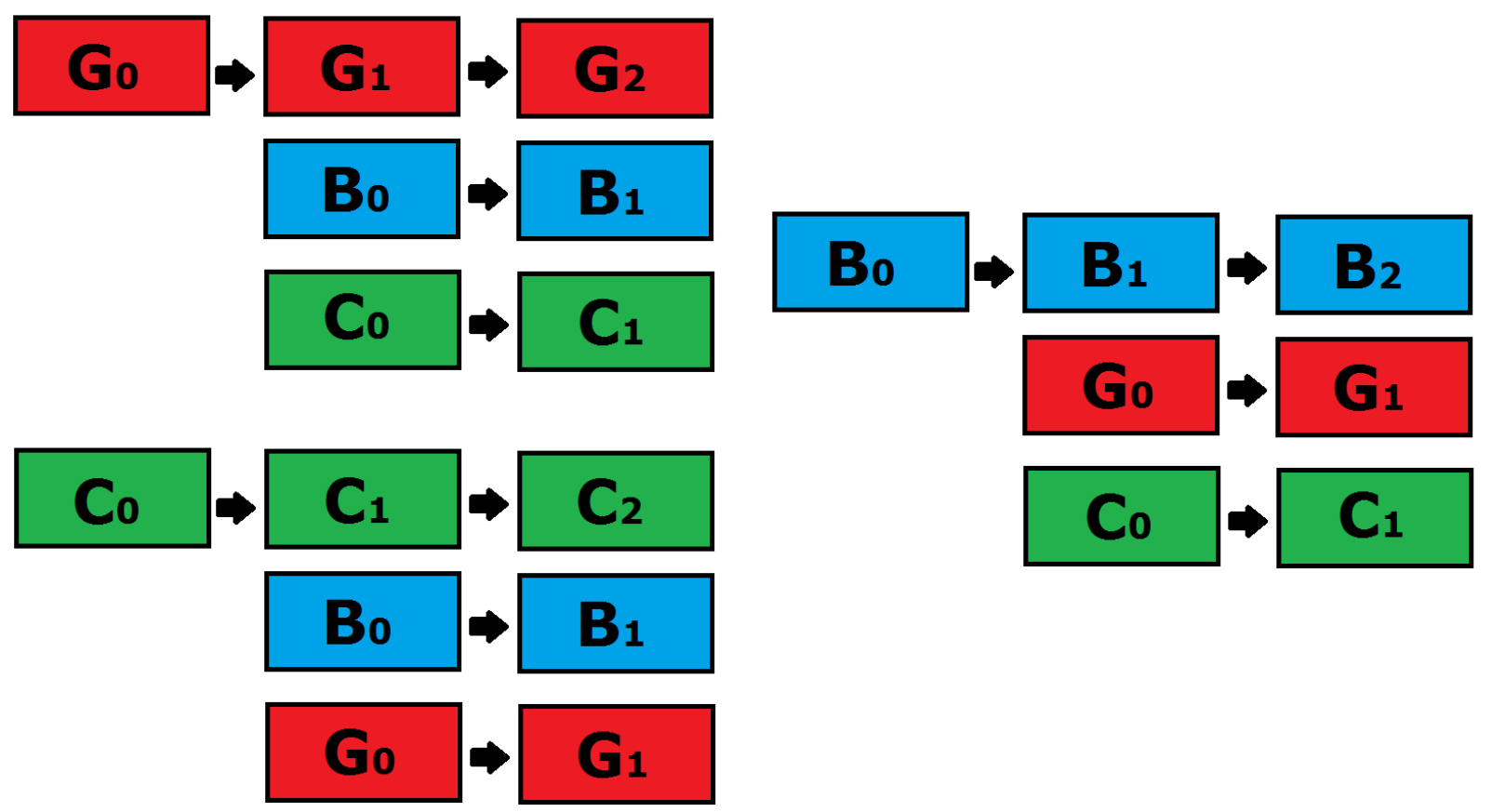

Figura 2.1: Funcionamento do NINJAM

As sessões no NINJAM possuem um metrônomo com o tempo pré-definido que será reproduzido para todos. Uma sessão com contrabaixo, bateria e guitarra, por exemplo, poderia ter a seguinte configuração: o baterista começa tocando sozinho sua parte no compasso $B_{0}$, compasso este que será composto de puro silêncio tanto para o guitarrista (trecho $G_{0}$ ) quanto para o contrabaixista (trecho $C_{0}$ ). No compasso 1 , para o guitarrista e o contrabaixista será reproduzido o que foi gravado em $B_{0}$ pelo baterista, quando então eles iniciam suas participações na jam, tocando suas partes indicadas por $G_{1}$ e $C_{1}$ respectivamente. Já para o baterista, que toca $B_{1}$, serão reproduzidos os trechos $G_{0}$ e $C_{0}$ gravados anteriormente (neste exemplo, silêncio). No compasso 2, cada instrumentista tocará 
algo novo $\left(B_{2}, G_{2}\right.$ e $\left.C_{2}\right)$ porém escutará o que os demais gravaram no compasso 1 , como pode ser observado na fig. 2.1. Logo, podemos notar que cada músico ouve a sua própria versão da jam.

\section{Discussão Comparativa}

Em geral, a meta é sempre obtermos uma latência que esteja dentro dos limites do limiar de performance em conjunto a fim de que o modelo de interação realística possa ser colocado em prática, já que se trata da abordagem mais próxima da performance tradicional e aquela que exige a menor quantidade de adaptações por parte do músico. Porém, como visto, nem sempre é possível garantir que a latência se mantenha abaixo dos 25 ms estipulados pelo limiar de performance em conjunto, já que a distância física impõe restrições muito fortes sobre isso.

Além disso, diferentes situações musicais podem admitir uma tolerância maior ou menor sobre a latência total percebida pelos músicos participantes de uma performance [K198, LK04]. Por exemplo, alguns tipos de improvisação musical são muito menos dependentes da existência de uma batida regular, permitindo que performances desse tipo sejam realizadas mesmo sob latências maiores do que as que o limiar de performance em conjunto considera ideal. Mesmo em cenários musicais em que existe um pulso regular, a tolerância à latência também acaba variando dependendo da frequência deste pulso (tempo): em uma peça lenta um atraso maior pode ser menos incômodo e gerar menores dificuldades para a interação musical se comparado a uma peça que possui um ritmo mais acelerado.

Podemos ressaltar também que, no caso do modelo de retorno atrasado, a interação do músico com seu instrumento é modificada devido ao atraso artificialmente introduzido à sua resposta. Embora isso não seja o ideal, uma situação semelhante ocorre naturalmente durante o aprendizado das técnicas de diversos instrumentos. Por exemplo, no caso de um pianista, dependendo da intensidade musical que o intérprete deseje expressar, o tempo entre o pressionar de uma tecla e o início dessa nota pode variar de 30 a 100 ms [LK04, AJ90]. De forma semelhante, é possível que com o devido treinamento o músico consiga lidar com latências maiores introduzidas artificialmente para que uma performance musical distribuída seja bem sucedida.

Diversos tipos de performance podem ser realizadas usando uma mesma implementação de software. No caso dos modelos de interação realística, mestre e escravo, abordagem relaxada e aceitação da latência, não há diferenças entre eles sob o aspecto computacional, sendo que suas características se distinguem especialmente do ponto de vista artístico e das medidas de latência alcançadas pela rede.

Todos os modelos de interação propostos, excetuando-se o modelo de interação realística, buscam permitir a execução de performances musicais distribuídas em que a latência supera o limiar de performance em conjunto. Porém todos eles possuem limitações que impedem que um deles seja escolhido como o ideal em todas as situações possíveis. O modelo mestre e escravo faz com que pelo menos uma das partes sempre saia insatisfeita com a forma de interação, já que para ela o retorno é indiferente, e a performance em grupo passa a ser, na prática, uma performance individual. Tanto o modelo de aceitação da latência quanto o modelo da abordagem relaxada e o modelo do tempo falso estão limitados a certos estilos musicais que se adequam à proposta destes modelos, já que se torna impossível que hajam partes exatamente sincronizadas. E o modelo de retorno atrasado, embora seja o modelo mais equilibrado, pois viabiliza que todos os estilos musicais sejam executados, ocasiona certos inconvenientes para o músico, exigindo um certo grau de adaptação e ensaios com a finalidade de que a latência induzida artificialmente na resposta do instrumento passe a ser considerada natural.

\subsection{Redes de Computadores}

\section{Latência}

A latência é a demora que ocorre ao enviarmos uma informação de um local para outro, não podendo ser eliminada completamente já que estamos limitados a transmitir as informações, no máximo, na velocidade da luz. Ela depende principalmente do meio físico em que a informação está sendo 
enviada, variando se a transmissão é feita através de cabos de cobre, de fibra ótica ou até mesmo pelo ar.

Usualmente, no caso de redes como a Internet, a transmissão é realizada por cabos de fibra ótica até chegar na chamada "última milha", que conecta o usuário final na rede global. Neste trecho, a conexão geralmente é feita através de cabos de cobre devido ao seu custo menor.

A transmissão de dados via fibra ótica tem cerca de $70 \%$ da velocidade da luz [Hec02]. Assim, descontando-se diversos fatores como a estrutura das redes por onde trafegam os dados da Internet e os atrasos ocasionados pela passagem dos pacotes nos diversos roteadores que existem no caminho, podemos calcular a distância máxima aproximada para que seja possível a prática de performances musicais distribuídas dentro do limite de 25 ms do limiar de performance em conjunto:

$$
25 \mathrm{mS} \times \frac{1 \not}{1000 \mathrm{mS}} \times \frac{300000 \mathrm{~km}}{1 \not \mathrm{s}} \times \frac{70}{100}=5250 \mathrm{~km}
$$

Portanto, imaginando um cenário ideal, poderíamos realizar performances musicais distribuídas com o modelo de interação realística a até cerca de $5250 \mathrm{~km}$ de distância, o que é bastante promissor, já que a distância de São Paulo até o Panamá, por exemplo, é de cerca de $5100 \mathrm{~km}$ em linha reta, mostrando que este raio de alcance permitiria a interação entre músicos de diferentes culturas e, de forma mais interessante para músicos brasileiros, também entre quaisquer cidades do Brasil. Porém, diversos fatores impedem que isso seja possível. Por exemplo, a infraestrutura dos backbones de Internet pode não permitir que a latência mínima entre dois pontos seja alcançada. Muitas vezes, não existem conexões em que a distância percorrida na rede seja exatamente àquela distância em linha reta já que para implantar esta infraestrutura é possível encontrar obstáculos como montanhas, estradas, etc. Assim, é possível que, para conectarmos dois computadores em cidades razoavelmente próximas, seja necessário percorrer um trajeto muito maior. Além do aumento da distância efetiva percorrida, as conexões indiretas também têm o tempo de conexão aumentado pela introdução de buffers em cada nó do backbone.

Na Rede Ipê [RNPa], utilizada para fins de ensino e pesquisa no Brasil, diversas cidades não estão conectadas diretamente, como pode ser visto na fig. 2.2. Conexões entre Fortaleza e Teresina (distantes cerca de $500 \mathrm{~km}$ em linha reta entre si), por exemplo, obrigam que os pacotes de dados trafeguem até Recife ou Belém, já que não existe um canal direto entre elas, aumentando a distância total a ser percorrida pelos dados para mais de $1500 \mathrm{~km}$ em linha reta passando por Recife e mais de $1800 \mathrm{~km}$ via Belém. Esse tipo de limitação da infraestrutura dos backbones de Internet pode fazer com que mesmo cidades razoavelmente próximas tenham latências mais altas do que o necessário, impossibilitando uma interação através do modelo realístico. Outros casos bastante críticos podem ser observados na região norte do Brasil, onde cidades como Manaus, Boa Vista, Rio Branco e Macapá não possuem conectividade direta entre elas, fazendo com que a informação tenha que passar por cidades como Brasília e São Paulo e possivelmente impossibilitando uma performance musical interativa entre estas cidades da região.

Embora a Rede Ipê não retrate fielmente a Internet comercialmente disponível, casos semelhantes a esse certamente podem ser encontrados tanto no Brasil quanto no exterior, já que o custo de implantação de uma infraestrutura torna-se menor ao ser feita de forma similar à da Rede Ipê, fazendo com que a latência real da conexão seja muito maior do que a teórica, que dependeria somente da distância entre os pontos conectados e mostrando como a infraestrutura de rede influencia diretamente na latência real observada por participantes de performances musicais distribuídas.

\section{Jitter}

Além da latência da rede, outra questão do roteamento que o usuário caseiro não possui nenhum tipo de controle é o trajeto que o pacote percorre para chegar ao seu destino. A rota utilizada para transmissão de dados de um computador ao outro não é necessariamente igual em todos os momentos, podendo mudar de um pacote para o outro de acordo com o que os algoritmos de roteamento de cada equipamento decidirem naquele instante. Assim, na realidade, a latência entre dois pontos raramente 


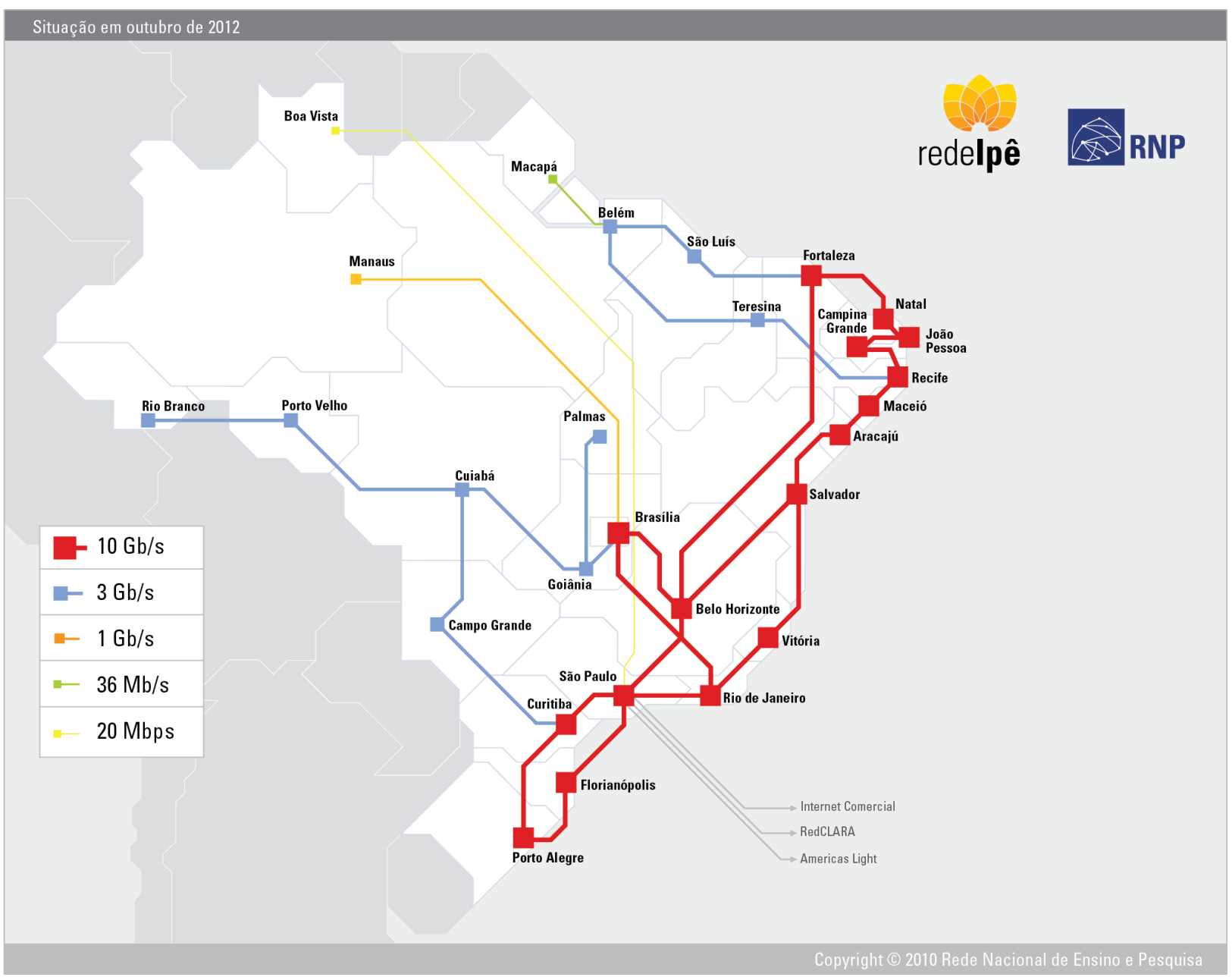

Figura 2.2: Backbone da Rede Ipê [RNPb]

permanece constante, sendo essa variação chamada de jitter.

Outra causa para essa oscilação é a taxa de utilização da rede, já que, no caso da Internet, a mesma é compartilhada por milhões de usuários, fazendo com que os equipamentos que realizam a transmissão de dados estejam sujeitos a diferentes níveis de carga a todo instante e seja necessário realizar um escalonamento dos pacotes, variando assim o tempo de resposta de cada pacote enviado pela rede.

Por causa do jitter, é preciso que haja um buffer de tamanho adequado para que não ocorram falhas na reprodução do áudio, já que a taxa de reprodução é constante, usualmente de 44100 amostras por segundo, e, se o dado necessário não for entregue a tempo, um pequeno "clique" será ouvido pelo usuário caso não seja realizado nenhum tipo de processamento do áudio. Se a latência fosse constante, não haveria a necessidade de um buffer, já que teríamos a garantia de transmissão de um fluxo ininterrupto de dados, havendo apenas um atraso no início da reprodução, causado pela própria latência.

Mesmo com a implementação deste buffer, não é garantido que não hajam falhas na reprodução, já que é possível que ocorra uma situação em que os atrasos sejam tão grandes que o buffer seja pequeno demais e então aconteça uma condição de esvaziamento de buffer e não hajam amostras a serem reproduzidas. Aumentar indiscriminadamente o tamanho do buffer também é problemático, já que haverá um aumento na latência de reprodução do som, algo indesejado na área das performances musicais distribuídas. 


\section{Largura de Banda}

Outro aspecto muito importante para as performances musicais distribuídas é a largura de banda disponível para a transmissão de dados. A largura de banda é uma medida que indica a capacidade máxima de transmissão de dados sobre um canal de rede, normalmente medida em bits por segundo. O espaço e banda necessários para armazenamento e envio de áudio digital de alta qualidade é razoavelmente alto, sendo que uma das poucas aplicações que possui demandas maiores que as de áudio é a codificação de vídeo digital.

A norma IEC 60908 [C ${ }^{+}$99] define o padrão Red Book em que é estabelecido o formato utilizado no CD: são armazenados dois canais de áudio onde temos, por segundo, 44100 amostras com 16 bits em cada canal de áudio. Com isso, precisamos de $44100 \times 16 \times 2 \approx 1411 \mathrm{kbps}$ para transmitir áudio com alta qualidade.

Aqui entram limitações da Internet disponível amplamente ao público brasileiro: atualmente, a maioria das empresas não oferece taxas de upload suficientemente altas para que seja possível o envio em tempo real desse tipo de fluxo de dados. As soluções comerciais disponíveis na cidade de São Paulo em fevereiro de 2013 oferecem taxas de upload médias de cerca de 1 Mbps, insuficientes para a prática de performances musicais distribuídas de alta qualidade, em contraste com as taxas de download que chegam a alcançar 20 Mbps ou mais.

Dentre as formas de se viabilizar as performances musicais distribuídas sob tais condições, podemos diminuir a qualidade de áudio, diminuindo a taxa de amostragem e/ou resolução das amostras. Por exemplo, se cada amostra utilizar 8 bits ao invés dos 16 citados, torna-se possível transmitir um canal de áudio em tempo real, já que a banda necessária seria de apenas $44100 \times 8=352 \mathrm{kbps}$. Em contrapartida, a perda de qualidade do áudio seria bastante grande em relação à economia de banda, já que atualmente temos codificadores muito mais avançados que possibilitam a representação de áudio com alta qualidade para o ouvido humano com taxas de bits tão baixas quanto 192 kbps para sinais estéreo, como é o caso do MP3, Vorbis e AAC (Advanced Audio Coding), os mais conhecidos codificadores de áudio com perdas.

\section{Protocolos}

A comunicação pela rede em performances musicais distribuídas geralmente é feita utilizando o protocolo UDP. Ao contrário do TCP comumente utilizado na Internet, o UDP não possui diversas características do TCP como a garantia de recebimento do pacote pelo destinatário, por exemplo.

No UDP, os pacotes são extremamente simples, contendo apenas um cabeçalho que indica as portas de origem e destino utilizadas, o tamanho da mensagem, um checksum (ou soma de verificação) que testa se o pacote não está com suas informações corrompidas e os dados da mensagem em si.

O UDP é bastante utilizado em aplicações com transmissão de dados em tempo real, dado que é um protocolo bastante simples e leve, adicionando pouco overhead devido ao seu pequeno cabeçalho. Além disso, diversas qualidades trazidas pelo TCP não são úteis nessas aplicações, já que, caso haja perda de pacotes, não é necessária a retransmissão deste pacote numa situação em tempo real, pois o evento perdido já ocorreu e novos eventos estão sendo gerados a todo instante. A ordenação de pacotes do TCP também não é interessante neste caso porque pode haver uma longa espera para que um pacote que esteja preso em um ponto de congestionamento da rede chegue ao seu destinatário, fazendo com que a latência final aumente consideravelmente, algo indesejável nas performances musicais distribuídas.

\section{Topologia da Rede}

Outro aspecto que possui impacto sobre a questão de uso da rede é a estrutura escolhida para realizar as conexões entre os usuários das performances musicais distribuídas. No caso de dois músicos que estejam interagindo não há diferença prática, porém, ao adicionarmos mais elementos ao grupo, a topologia da rede passa a influenciar consideravelmente. 


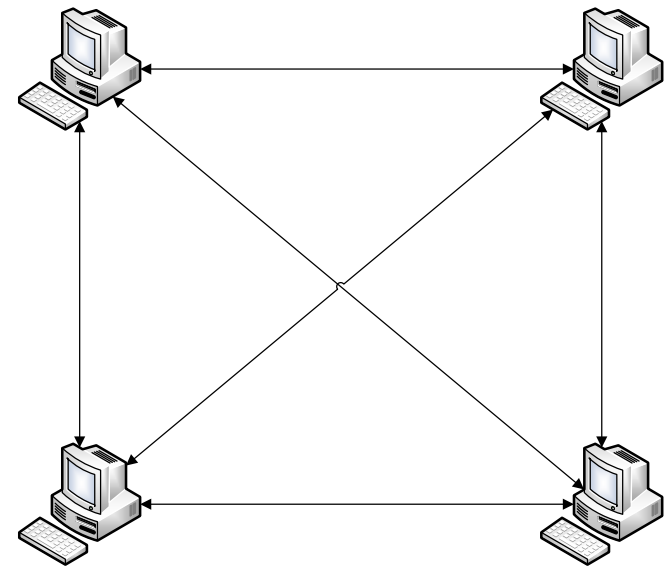

(a) Par-a-par

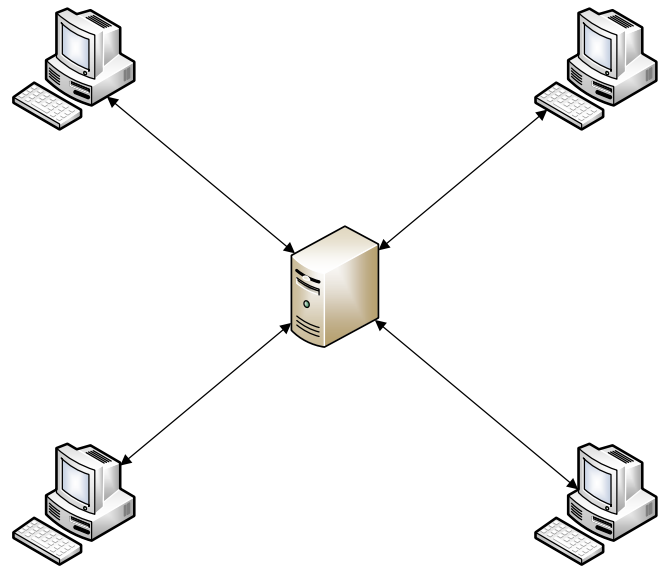

(b) Servidor-Cliente

Figura 2.3: Topologias de Rede

A topologia da rede indica qual é o modo em que os vários computadores conectam-se entre si. Podemos discutir tanto o aspecto físico quanto o aspecto lógico das conexões. A topologia física indica como são realizados os cabeamentos e os tipos de equipamentos envolvidos no meio (hubs, switches, etc.), enquanto a parte lógica indica qual o fluxo de dados na rede, independentemente de como as conexões físicas são realizadas.

Como estamos discutindo conexões realizadas principalmente através da Internet, o usuário final não possui controle sobre a topologia física da rede, apenas o provedor utilizado tem o poder de alterar a forma de cabeamento e os equipamentos envolvidos. Então, nosso foco será dado às diferenças causadas pelas escolhas no nível do software em relação a como os pacotes podem ser transmitidos, quando diversos participantes estão conectados à sessão de uma performance musical distribuída.

Dois modelos de topologia são comumente utilizados ao lidarmos com aplicações que envolvam o uso de Internet: par-a-par (P2P) e servidor-cliente (também chamado de estrela), como indicados na fig. 2.3.

Se as conexões forem realizadas de forma P2P, cada usuário deve enviar o sinal de áudio que está sendo produzido por seu computador a todos os outros conectados em seu grupo, escalonando o uso de largura de banda linearmente conforme a existência de mais clientes na performance, o que certamente é um problema nestes casos em que a largura de banda já é um limitante apenas para um par de PCs conectados entre si.

Já a estrutura tradicional centralizada de conexões servidor-cliente não possui esse tipo de dificuldade, pois cada cliente precisa enviar seu áudio apenas para o servidor, que redistribuirá o áudio para cada um dos usuários conectados no mesmo grupo. Isso exige que apenas uma das máquinas (o servidor) possua uma grande capacidade para envio e recebimento de dados. Neste caso, o inconveniente passa a ser a necessidade de se ter acesso a um servidor dedicado para tal tarefa, algo que não é comum a usuários caseiros e só possível com um custo extra.

\section{Conectividade}

A quantidade de endereços IP disponíveis na Internet é limitada pelo protocolo IPv4, endereçado por números de 32 bits no formato a.b.c.d, tal que $a, b, c, d \in[0,255]$, possibilitando a existência de $2^{32} \approx 4,3$ bilhões de endereços únicos, porém, dada a popularidade da Internet esta quantidade já não é mais suficiente. Para suprir esta necessidade foi criado o protocolo IPv6 que utiliza endereços de 128 bits para solucionar o problema. Porém, a adoção ao IPv6 vem sendo realizada de forma muito lenta. Em janeiro de 2013, estatísticas coletadas através do acesso de usuários aos serviços disponibilizados pela Google indicam que apenas cerca de $1 \%$ dos acessos são realizados através do protocolo IPv6 ${ }^{2}$.

\footnotetext{
${ }^{2}$ http://www.google.com/ipv6/statistics.html
} 
Por isso, a alternativa amplamente utilizada para contornar o problema de endereçamento no IPv4 é o uso de NAT (Network Address Translation ou Tradução de Endereços de Rede) [TW10].

A ideia por trás da utilização de NAT é bastante simples: suponha que um usuário assine um serviço de acesso à Internet. Normalmente, o provedor disponibiliza um IP para que ele possa se comunicar com o restante da Internet. Este endereço é considerado um IP público. Agora imagine que este assinante possua um outro membro da sua família que deseja usufruir da Internet ao mesmo tempo que ele através de um dispositivo como, por exemplo, um segundo computador, um laptop ou um telefone móvel. Neste caso, o usuário não gostaria de ter de contratar mais um plano com o provedor de Internet, mas sim compartilhar a sua conexão contratada com mais de um dispositivo. Um cenário semelhante é encontrado em empresas, onde diversos funcionários precisam de acesso à Internet porém o custo de se contratar um plano de acesso para cada um se torna alto demais.

A solução tipicamente usada em ambos os casos é montar uma rede interna, conectar um roteador a ela e habilitar o acesso à Internet através deste roteador. Nesta rede, cada dispositivo terá o seu próprio endereço privado único, porém, para quem observa de fora da rede, toda ela é representada por apenas um IP público, aquele fornecido pelo provedor. A função do NAT é, como o próprio nome indica, traduzir os endereços privados (usados internamente) para os públicos (usados na Internet) e vice-versa.

Alguns intervalos de endereços IP foram definidos pela IANA (Internet Assigned Numbers Authority) $\left[\mathrm{RMK}^{+}\right.$96] para o uso em redes privadas (tabela 2.1). O uso destes está liberado para qualquer finalidade, não sendo endereços válidos na Internet, ou seja, um pacote com remetente ou destinatário de um destes intervalos deve trafegar apenas internamente em uma rede privada, não sendo permitido o aparecimento deles na rede mundial de computadores.

\begin{tabular}{ll}
\hline Início & Fim \\
\hline 10.0.0.0 & 10.255 .255 .255 \\
172.16.0.0 & 172.31 .255 .255 \\
192.168.0.0 & 192.168 .255 .255 \\
\hline
\end{tabular}

Tabela 2.1: Intervalos de endereços IP para uso privado

Diversos tipos de NAT são possíveis, devido às diversas implementações feitas pelos fabricantes destes dispositivos. Em [RWHM03], alguns tipos de NATs foram detalhadas, porém, o uso da terminologia empregada em tal documento não se mostrou adequada para refletir o estado dos comportamentos observados nestes equipamentos, o que levou à criação da RFC 4787 [AJ07] em que novos termos foram definidos.

Quando um equipamento interno $i$ precisa enviar um pacote através de um NAT para a rede externa e, um mapeamento é feito pelo dispositivo NAT entre as tuplas $\left(\mathrm{IP}_{i}\right.$, porta $\left._{i}\right)$ e $\left(\mathrm{IP}_{e}\right.$, porta $\left._{e}\right)$ para que seja possível que o equipamento interno recebas as possíveis respostas enviadas através da rede externa. A caracterização destes mapeamentos se dá principalmente de acordo com o comportamento observado após o estabelecimento do primeiro mapeamento realizado. Os seguintes termos foram definidos para categorizar os mapeamentos feitos entre endereços e portas privadas e públicas:

- Mapeamento Independente do Ponto Final

A partir do momento em que uma porta de um endereço interno é utilizada para o envio de pacotes, todo e qualquer pacote seguinte enviado por tal porta utilizará o mesmo mapeamento, independentemente do endereço ou porta de destino.

- Mapeamento Dependente de Endereço

O NAT reutilizará o mapeamento caso os pacotes seguintes sejam enviados para o mesmo endereço, independentemente da porta. Caso seja enviado um pacote através desta porta para um segundo destinatário, um novo mapeamento será realizado. 
- Mapeamento Dependente de Endereço e Porta

O mapeamento passa a depender tanto do endereço quanto da porta de destino, sendo criado um novo mapeamento para cada destino distinto nos pacotes a serem enviados pela mesma porta de origem.

Outro aspecto importante de ser caracterizado para os NATs é a filtragem realizada pelo dispositivo em relação aos pacotes provenientes da rede externa para a rede interna, sendo o processo inverso ao mapeamento. As características são semelhantes às dos mapeamentos:

- Filtragem Independente do Ponto Final

Uma vez que o mapeamento é feito, o NAT passa a redirecionar todo e qualquer pacote que chega na porta externa mapeada ao destino na rede interna.

- Filtragem Dependente de Endereço

São redirecionados apenas os pacotes enviados do mesmo endereço público correspondente ao destino do pacote inicial.

- Filtragem Dependente de Endereço e Porta

Apenas pacotes enviados do mesmo endereço e porta públicos são redirecionados pelo mapeamento.

Dados estes modos de operação possíveis para os aparelhos de NAT e a ampla utilização deste tipo de dispositivo, começa a ficar claro alguns problemas para a realização de performances musicais distribuídas através de computadores dentro de redes privadas atrás de um NAT. Para o equipamento conectado a esta rede interna, o endereço IP ao qual ele é atribuído é um endereço válido apenas localmente em uma das faixas listadas na tabela 2.1.

Para que uma conexão P2P entre dois computadores seja bem sucedida, por exemplo, ambas as partes precisam disponibilizar o seu endereço público para a que a outra consiga se conectar. Isso é impossível atrás de um NAT sem a utilização de recursos externos já que não há nenhum tipo de indicador com a finalidade de obter o endereço público da máquina. Para auxiliar na descoberta do endereço público e dos tipos de mapeamento e filtragem do NAT, protocolos como STUN (Session Traversal Utilities for NAT) foram desenvolvidos.

Outros tipos de problemas ficam mais claros quando discutidos no contexto das técnicas usadas para atravessar um NAT como será feito em seguida.

\section{Atravessamento de NAT}

Para tentar solucionar os problemas ocasionados pela utilização de dispositivos de NAT diversas técnicas foram desenvolvidas, sendo normalmente chamadas de atravessamento de NAT. Essencialmente, dois tipos de procedimentos existem atualmente: métodos que abusam de alguma característica dos dispositivos de NAT na tentativa de aproveitá-la para realizar a conexão direta entre as partes, e protocolos que contam com a cooperação do NAT para configurá-lo de acordo com o desejado pela aplicação.

Na primeira categoria se encontram técnicas como conexão reversa, perfuração (hole punching) [FSK05, SFK08], STUN [RWHM03, RMMW08], TURN [MMR10] e ICE [Ros10, WP11], enquanto na segunda estão os protocolos como NAT-PMP [CK13] e UPnP IGD [For10].

Conexão Reversa Trata-se do caso mais simples, em que um dos participantes $(A)$ não está atrás de um NAT, possuindo um endereço IP público. Neste caso, se a conexão for iniciada pelo usuário atrás do NAT $(B)$, tudo ocorre sem problemas, já que $A$ receberá os pacotes enviados normalmente e suas respostas serão corretamente direcionadas, independentemente do mapeamento e da filtragem utilizadas pelo NAT. Caso a conexão tente ser iniciada por $A$, ela não será bem-sucedida, já que o 
mapeamento feito pelo NAT em $B$ ainda não existe. Então, o método da conexão reversa simplesmente utiliza uma terceira máquina, acessível através de um endereço público conhecido, para atuar como ponto de encontro e faz com que $A$ envie uma mensagem para $B$ através dele pedindo que $B$ inicie a conexão.

Perfuração Um cenário comum é quando ambos os participantes $A$ e $B$ estão atrás de um NAT. Neste caso, uma técnica como a conexão reversa é inadequada já que os mapeamentos não existem em nenhuma das partes. Então pode-se tentar aplicar a técnica de perfuração ou hole punching. Elas existem tanto para o protocolo TCP quanto para o UDP, mas, como a aplicação destes métodos no caso deste texto é focado em sua utilização em performances musicais distribuídas, discutiremos apenas os procedimentos para o UDP. Novamente, um terceiro servidor público $S$ é utilizado como ponto de encontro. $A$ e $B$ se conectam a $S$ e enviam seus endereços e portas públicas e privadas. Quando $A$, por exemplo, desejar realizar uma conexão $\operatorname{com} B$, ele pede os endereços para este servidor que também envia para $B$ esta informação sobre $A$. Com isso, $A$ e $B$ passam a mandar mensagens UDP tanto para o endereço/porta público quanto para o privado e a conexão pode se tornar viável.

$O$ resultado obtido dependerá da estrutura da rede e da forma como os NATs se comportam. Caso $A$ e $B$ na realidade pertençam à mesma rede, o par endereço/porta privado certamente permitirá a conexão. Caso contrário, o tipo de filtragem do NAT pode ocasionar problemas. Se os NATs realizarem uma filtragem independente do ponto final, o mapeamento feito ao se conectar a $S$ continua sendo válido e todo pacote que chegar de uma das partes será entregue corretamente. Para a filtragem dependente de endereço e endereço/porta, apenas as respostas de $S$ são repassadas corretamente, enquanto que as mensagens vindas de $A$ ou $B$ passam a ser descartadas pelo NAT, impedindo a conexão.

Uma heurística possível de ser utilizada é o uso de várias conexões com $S$ para tentar descobrir qual o algoritmo de mapeamento de portas utilizado pelo NAT. Por exemplo, se a alocação de portas no NAT for sequencial, $S$ pode comunicar para $A$ e $B$ realizarem a conexão não através da porta usada na conexão entre eles e $S$, mas sim na seguinte, o que pode ser bem sucedido. Porém, ainda é impossível garantir a conectividade utilizando estas técnicas.

STUN Foi inicialmente definido no RFC 3489 como uma solução completa para atravessamento de NAT, sendo o acrônimo de Simple Traversal of UDP through NAT (Travessia Simples de UDP através de NAT). Desde então, ele foi declarado obsoleto pelo RFC 5389, pois sua antiga versão não caracterizava adequadamente os tipos de NAT disponíveis nos equipamentos e o algoritmo utilizado para atravessar NATs não era confiável o suficiente para garantir sua padronização. Assim, o STUN passou a ter um outro uso, auxiliando na tarefa de travessia de NATs, porém não sendo responsável por tal, o que gerou seu novo nome: Session Traversal Utilities for NAT (Utilitários para Atravessar Sessões para NAT).

A única responsabilidade da ferramenta definida no RFC 5389 é o de realizar uma das etapas da técnica de perfuração, com o método chamado Binding. Outros métodos podem ser definidos com outras funcionalidades, como, por exemplo, descobrir qual o tipo de NAT de um dispositivo [ML10].

Um cliente STUN envia uma requisição do tipo Binding para um servidor STUN. Ao passar por um NAT, o endereço privado original do pacote é sobrescrito pelo endereço público mapeado pelo NAT. Assim, o servidor, ao receber esta mensagem, copia o endereço de origem deste pacote para o corpo da resposta realizando uma operação XOR do endereço com a constante hexadecimal 0x2112A442 e a envia de volta para o cliente, fazendo com que este seja informado de seu endereço público. O uso de um XOR ao invés de uma cópia simples do endereço é feita para fins de ofuscamento pois alguns NATs podem detectar a presença do IP e porta públicos no próprio corpo da mensagem e substituí-los pelo endereço privado, o que negaria a utilidade do método.

TURN No caso em que as técnicas de perfuração falham, a única solução é a utilização de servidores de redirecionamento (relay), em que um servidor conhecido por todos recebe as conexões e repassa 
todos os dados a serem enviados entre as partes, fazendo com que a conexão entre elas passe a ser indireta. Embora esta seja a alternativa mais garantida para que a conexão ocorra, há um gasto desnecessário de processamento, largura de banda e um aumento na latência entre as duas partes que desejavam uma conexão direta, o que é bastante indesejado para as performances musicais distribuídas. O protocolo TURN (Traversal Using Relays around NAT ou Atravessar NAT Usando Retransmissores) define um padrão para este tipo de conexão.

ICE O RFC 5245 propõe uma solução completa para atravessamento de NATs que combina diversas técnicas, incluindo o STUN e o TURN. Essencialmente, o ICE (Interactive Connectivity Establishment ou Estabelecimento de Conectividade Interativa) forma uma listagem com todos os candidatos possíveis para que a conexão seja realizada, iniciando com o endereço da interface de rede local (possivelmente um endereço privado), passando a buscar o endereço público através do STUN e descobrindo se algum servidor para redirecionamento está disponível via TURN. Com esta listagem feita, são dadas prioridades a cada candidato, a fim de evitar que a conexão seja realizada através de um relay quando poderia ter havido uma troca de mensagens direta entre as partes, ou para evitar que as mensagens sejam transmitidas através da rede externa quando poderiam ter sido enviadas localmente quando as partes estão atrás do mesmo NAT. Então, é feita a checagem efetiva da conectividade dos elementos desta listagem e a conexão é finalmente estabelecida, sendo possivelmente necessária a utilização de um servidor de redirecionamento.

Redirecionamento de Portas Uma possibilidade para evitar estes problemas de NAT, especialmente no caso dos usuários domésticos ou empresas que possuem um roteador ligando a rede interna com a Internet, é configurar o equipamento manualmente através de uma opção muitas vezes disponibilizada chamada de redirecionamento de porta. Ao ativarmos esta opção, fixamos uma porta externa que terá todo o seu tráfego redirecionado a um nó interno que o usuário deseje, fazendo com que, na prática, este nó interno tenha um endereço público com o qual ele possa ser conectado. O problema desta abordagem é justamente a exigência de uma intervenção manual do usuário que, em muitos casos, não possui conhecimento suficiente para realizar tal operação.

UPnP IGD Este protocolo estabelece um método para que os aplicativos possam automaticamente criar uma porta a ser redirecionada para o computador do usuário sem a sua intervenção. Muitas vezes é oferecida como uma opção na interface de administração do equipamento, podendo ser desabilitada. Com o IGD (Internet Gateway Device ou Dispositivo de Passagem de Internet) o computador conectado a um NAT pode requisitar o seu endereço IP público, uma listagem dos mapeamentos de portas existentes, e pode adicionar ou remover um mapeamento de porta, dentre outras funções menos relevantes na tarefa de travessia de NATs, permitindo ao programa que necessite destes recursos de rede a configuração do dispositivo sem a intervenção do usuário.

NAT-PMP É uma alternativa ao UPnP IGD, oferecendo opções similares porém específicas para o controle do mapeamento de portas. Em janeiro de 2013, foi anunciado um esforço em conjunto com a IETF (Internet Engineering Task Force) para combinar os esforços do NAT-PMP (NAT Port Mapping Protocol ou Protocolo de Mapeamento de Portas NAT) com o PCP (Port Control Protocol ou Protocolo de Controle de Portas) na criação de um padrão para uso na Internet.

Estatísticas de Uso de NAT Em [MKC08], foram levantados dados sobre a utilização de equipamentos deste tipo e suas características. De 104 dispositivos testados, em uso na Alemanha, apenas $38,46 \%$ possuíam a opção de UPnP (Universal Plug and Play) habilitada, o que indica que uma aplicação infelizmente não pode depender somente deste tipo de protocolo. Em compensação, foi observado que ao utilizar técnicas de perfuração usando o protocolo UDP, a taxa de sucesso chegou a $92,31 \%$ dos casos, mostrando que a necessidade do uso de relays é consideravelmente baixa. 


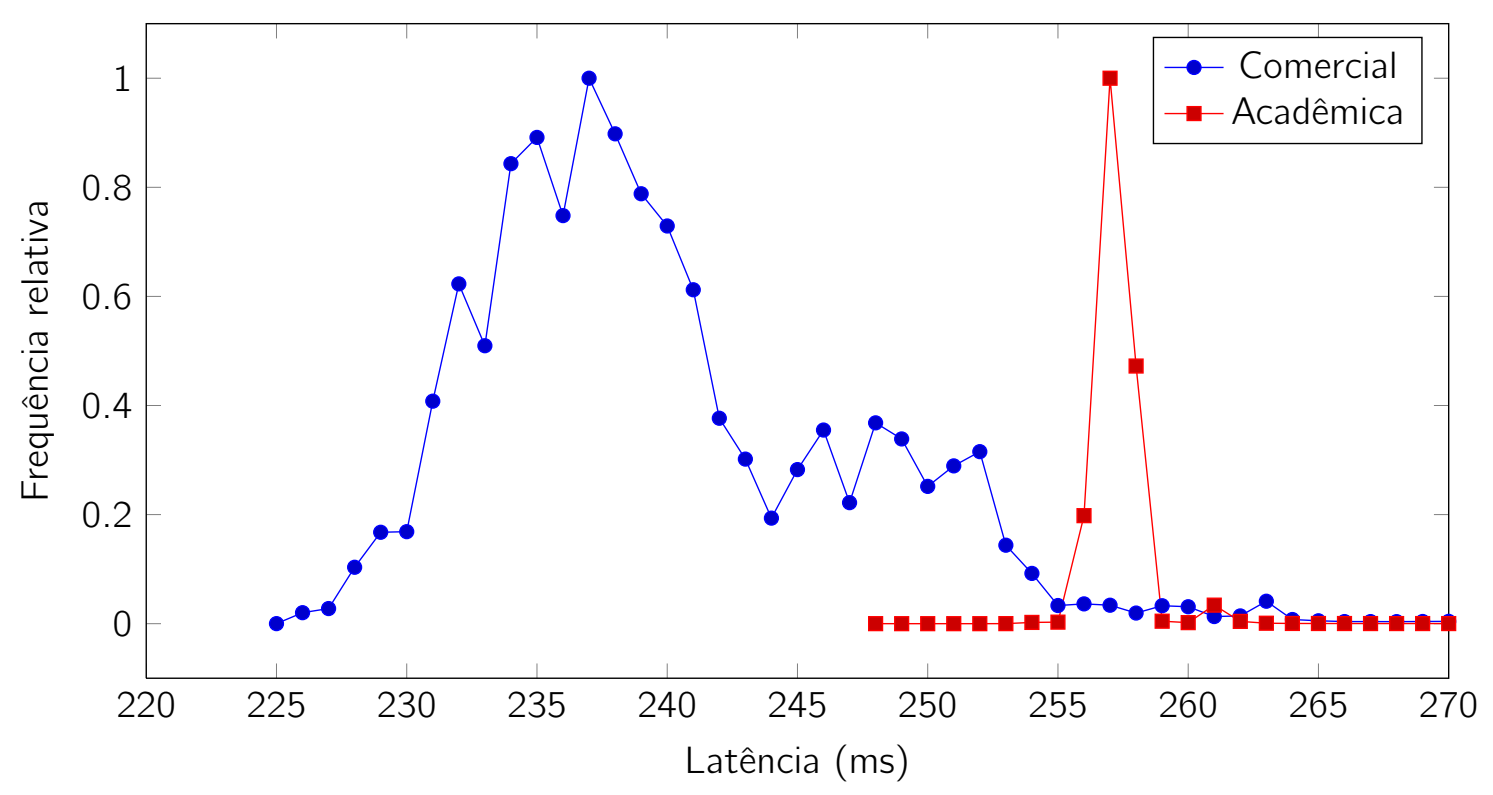

Figura 2.4: Histograma das latências observadas entre São Paulo e Belfast sob diferentes redes

\subsection{Performances em Internet Residencial}

Nesta seção, serão ilustradas algumas das diferenças que podem ser observadas ao se comparar o acesso à Internet disponível comercialmente ao público em geral e as redes utilizadas em ambientes acadêmicos e as implicações destas características nas soluções utilizadas nas aplicações de performances musicais distribuídas. Também será discutida a situação da Internet brasileira em março de 2013 em comparação com outras localidades no mundo e os rumos que devem ser observados futuramente.

A latência entre dois pontos, como já discutido anteriormente, depende diretamente da distância entre eles, existindo um limite mínimo. Logo, as diferenças entre redes comerciais e acadêmicas não devem ser significativas e dependerão exclusivamente do cabeamento realizado para cada um dos tipos de infra-estrutura, podendo serem reduzidas caso novos caminhos mais curtos forem sendo estabelecidos.

A característica mais interessante para diferenciar estas redes é a variação de latência (jitter) observada em cada uma delas. Durante o mês de janeiro de 2013, foi realizado um experimento em que o comando ping foi executado com destino a um computador localizado no SARC (Sonic Arts Research Centre) da Queen's University em Belfast, Irlanda do Norte. Como origem foram utilizados um computador localizado dentro do Instituto de Matemática e Estatística da Universidade de São Paulo, acessando a Internet através de uma rede acadêmica, e um computador também localizado em São Paulo, conectado à Internet através de um serviço de acesso através de fibra ótica comercialmente disponível na região central da cidade. A fig. 2.4 mostra um histograma normalizado das latências obtidas durante este período.

Dois aspectos das conexões podem ser observados: primeiramente, a latência média da conexão comercial é menor do que a obtida na rede acadêmica, o que, apesar de inesperado, não se mostra um resultado completamente anormal já que a diferença não é muito grande e as rotas utilizadas podem ser bastante diferentes, porém, o mais interessante de ser notado é a diferença de jitter entre as duas conexões. No caso da rede acadêmica, praticamente não há variação, com praticamente todos os pacotes situando-se em uma estreita faixa dos 255-260 ms, enquanto que na rede comercial, a faixa é muito mais larga, cobrindo dos 225 até os 255 ms.

Embora o Centro de Computação Eletrônica da Universidade de São Paulo possibilite que durante uma performance musical distribuída seja criada uma VLAN (Virtual LAN) entre os locais que farão parte da performance, possivelmente obtendo medições até melhores do ponto de vista da rede, durante a realização deste experimento não foi utilizada nenhuma configuração especial.

Os resultados deste experimento mostram que a utilização de um buffer em uma rede comercial, 


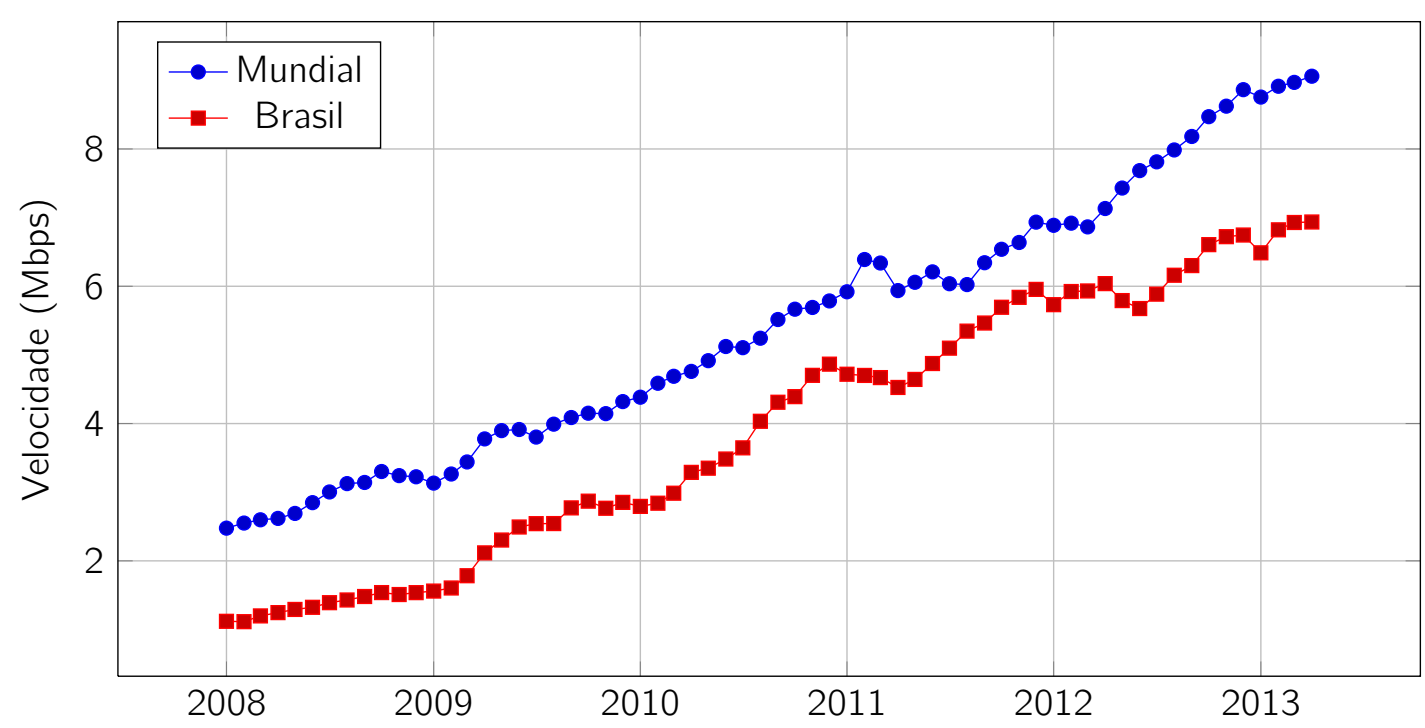

Figura 2.5: Comparação entre taxas de download brasileira e mundial

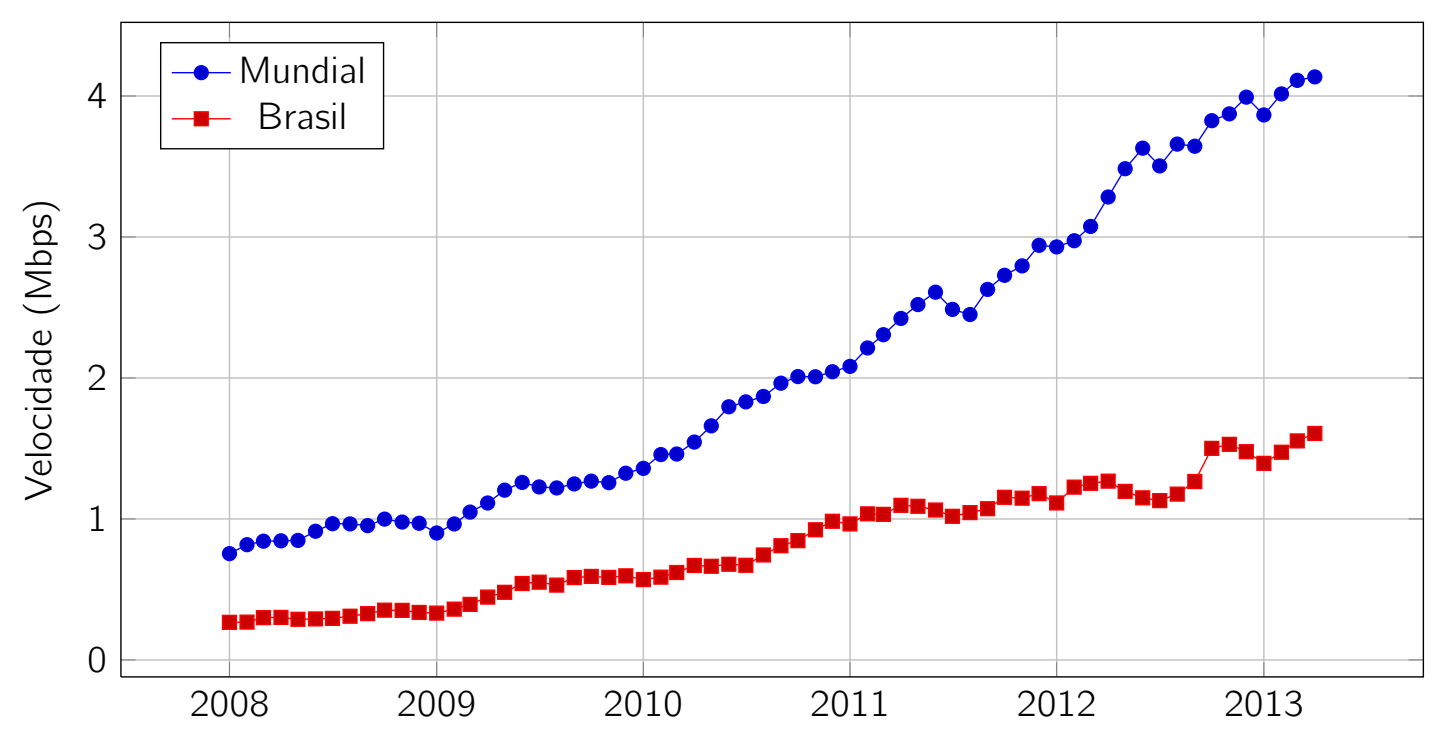

Figura 2.6: Comparação entre taxas de upload brasileira e mundial

além de necessária, também exige que seu tamanho seja maior do que em uma rede acadêmica, para evitar que a variação de latência ocasione falhas na reprodução de áudio. Considerando este experimento, isso negaria a pequena vantagem que a Internet comercial obteve ao atingir uma latência média menor do que a Internet acadêmica.

O outro aspecto que deve ser atentado na Internet residencial é a disponibilidade de largura de banda. Enquanto que no meio acadêmico a banda necessária para transmissão de diversos canais de áudio descompactado não oferece grandes dificuldades já que se tratam de redes que possuem conexões de até $10 \mathrm{Gbps}$, como ilustrado na fig. 2.2, no caso residencial a assimetria entre taxas de download e upload oferecidas acaba por oferecer restrições para performances musicais distribuídas residenciais.

Nas figs. 2.5 e 2.6 são comparadas as situações da Internet brasileira em relação ao desempenho global com dados obtidos pelo site de teste de velocidade de Internet SpeedTest ${ }^{3}$ desde janeiro de 2008 até março de 2013.

É possível observar algumas tendências bastante interessantes através destas informações: enquanto a taxa de download no território nacional acompanhou o crescimento da largura de banda internacional

\footnotetext{
${ }^{3}$ http://www.speedtest.net/ - Acessado em fevereiro de 2013
} 
de forma semelhante, mesmo que sejam elas consistentemente inferiores durante todo este período, no caso das taxas de upload ocorreu um fenômeno bastante diferente em que a banda disponível, apesar de também ter crescido durante este intervalo de tempo, claramente não teve a mesma evolução observada no cenário mundial.

Isso mostra que, embora grande parte dos computadores brasileiros conectados à Internet possuam largura de banda suficiente para receber dados de áudio sem nenhum tipo de compactação, a taxa de upload média impede que performances musicais distribuídas sejam realizadas adequadamente, sendo necessário o uso de algum codificador de alta eficiência como o implementado neste projeto. Mesmo considerando que exista a disponibilidade de largura de banda para o envio e recebimento simultâneo de áudio descompactado, devemos notar também que uma menor exigência neste quesito aumenta as possibilidades de uso desta largura de banda excedente para outros fins, como, por exemplo, o envio de sinais de vídeo juntamente com o áudio.

\begin{tabular}{|c|c|c|c|c|}
\hline Serviço & Download (Mbps) & Upload (Mbps) & $\begin{array}{r}\text { Franquia de } \\
\text { Consumo (Gbps) }\end{array}$ & Preço (R\$) \\
\hline \multirow[t]{5}{*}{ NET Virtua } & $512 \mathrm{kbps}$ & $256 \mathrm{kbps}$ & 10 & 29,80 \\
\hline & 1 & $300 \mathrm{kbps}$ & 20 & 54,90 \\
\hline & 10 & $800 \mathrm{kbps}$ & 80 & 129,90 \\
\hline & 20 & 1 & 100 & 179,90 \\
\hline & 100 & 3 & 150 & 399,90 \\
\hline \multirow[t]{5}{*}{ Vivo Fibra } & 15 & 1 & - & 114,99 \\
\hline & 25 & 5 & - & 124,99 \\
\hline & 50 & 10 & - & 129,99 \\
\hline & 100 & 15 & - & 229,99 \\
\hline & 200 & 40 & - & 349,99 \\
\hline \multirow[t]{5}{*}{ Vivo Plus } & 1 & $250 \mathrm{kbps}$ & - & 59,90 \\
\hline & 15 & 1 & - & 84,90 \\
\hline & 25 & 1 & - & 104,90 \\
\hline & 50 & 1 & - & 134,90 \\
\hline & 100 & 3 & - & 234,90 \\
\hline \multirow[t]{7}{*}{ GVT } & 5 & $750 \mathrm{kbps}$ & - & 124,80 \\
\hline & 10 & 1 & - & 144,80 \\
\hline & 15 & 1 & - & 154,80 \\
\hline & 25 & 2 & - & 164,80 \\
\hline & 35 & 3 & - & 169,80 \\
\hline & 50 & 5 & - & 319,70 \\
\hline & 150 & 15 & - & 469,80 \\
\hline \multirow[t]{8}{*}{ Oi Velox } & $300 \mathrm{kbps}$ & $128 \mathrm{kbps}$ & 20 & 89,90 \\
\hline & $600 \mathrm{kbps}$ & $300 \mathrm{kbps}$ & 20 & 89,90 \\
\hline & 1 & $300 \mathrm{kbps}$ & 40 & 89,80 \\
\hline & 2 & 512 kbps & 50 & 99,90 \\
\hline & 5 & $512 \mathrm{kbps}$ & 60 & 109,90 \\
\hline & 10 & $512 \mathrm{kbps}$ & 80 & 119,90 \\
\hline & 15 & 1 & 100 & 129,90 \\
\hline & 20 & 3 & 100 & 179,90 \\
\hline \multirow[t]{2}{*}{ Oi Fibra } & 50 & 10 & 200 & 149,90 \\
\hline & 100 & 15 & 500 & 189,90 \\
\hline \multirow[t]{2}{*}{ Live TIM } & 35 & 20 & - & 59,90 \\
\hline & 50 & 30 & - & 89,90 \\
\hline
\end{tabular}

Tabela 2.2: Serviços de Internet oferecidos em São Paulo e Rio de Janeiro (março de 2013) 
Além disso, apesar do cenário apresentado nas figs. 2.5 e 2.6 possa parecer animador, uma análise dos planos de Internet oferecidos em fevereiro de 2013 em grandes centros brasileiros como São Paulo e Rio de Janeiro mostra uma realidade ligeiramente diferente. Na tabela 2.2, estão listados diversos serviços de acesso à Internet destas cidades.

Podemos observar que na grande maioria dos planos oferecidos, a taxa de upload é bastante baixa mesmo quando são possíveis downloads de até $100 \mathrm{Mbps}$. Para ilustrar esta discrepância, nestes casos em que temos 100 Mbps para recebimento de dados e apenas 3 para envio, seria possível receber 148 canais de áudio independentes com qualidade de CD enquanto somente poderíamos mandar 4 canais nas mesmas condições.

Outro problema que pode ser identificado no serviço de Internet brasileiro através desta tabela é a existência de franquias de consumo, em que, no momento que um usuário transmita mais dados do que seu plano permite, a velocidade de sua Internet pode ser reduzida até o final do mês ou tarifas extras sejam cobradas. Além disso, o custo para se contratar este tipo de serviço é alto e depende de uma variedade de combinações de outros serviços que as prestadoras oferecem. Taxas de instalação e habilitação ainda são cobradas à parte por alguns dos provedores, dificultando a análise de custo de cada um dos planos.

Porém, também é possível observar que alguns dos meios de acesso disponibilizados oferecem taxas de upload mais generosas. Nestes casos (Vivo Fibra, Oi Fibra e Live TIM), é oferecido o acesso à Internet através de fibra ótica e tratam-se de serviços cuja disponibilidade ainda se restringe a algumas áreas específicas de cada cidade. É de se esperar que futuramente o acesso a estes planos seja melhorado através da expansão da rede de fibra ótica e, com isso, as taxas de envio de dados observem uma menor discrepância em relação às taxas de recebimento, ao contrário do que é observado atualmente. Isso beneficiaria aqueles que desejam realizar performances musicais distribuídas, permitindo até que áudio sem compactação seja utilizado e oferecendo mais possibilidades de se explorar o excedente de largura de banda disponível. 


\section{Capítulo 3}

\section{Implementação}

Diversas das escolhas tomadas no desenvolvimento do JackTripMod tiveram como ponto inicial algumas das soluções já apresentadas por alguns dos softwares para a prática de performances musicais distribuídas. Neste capítulo, analisaremos algumas das soluções já disponíveis e detalharemos as modificações realizadas no JackTrip com foco no objetivo do trabalho.

Muitas das características que serão discutidas serão bastante focadas no ponto de vista do usuário caseiro, já que no ramo acadêmico diversos dos problemas apresentados possuem um grau de influência muito menor do que o observado na internet residencial, ou são irrelevantes.

Embora o maior interesse de diversos estudos acadêmicos seja em performances distribuídas entre várias localidades muito distantes, como é possível observar nos experimentos já citados na seção 1.1.1, a grande lacuna que falta ser preenchida pelos softwares já desenvolvidos é incentivar a exploração das performances musicais distribuídas entre usuários que estejam numa vizinhança próxima, onde a latência seria obviamente menor e permitiria uma interação mais natural entre as partes.

A internet encurtou as distâncias entre as pessoas, facilitando a interação social e a troca de informações. Um grande exemplo disso são os grupos de discussão que se estabeleceram e permitem a reunião de indivíduos com interesses comuns para ambas as finalidades. Logo, seria de se esperar que o mesmo fosse ocorrer com a interação musical, mas esse não é o cenário que podemos observar atualmente.

A existência de uma grande quantidade de recursos educacionais na internet também potencializou o ensino musical tanto através de meios ilegais, como o acesso a materiais protegidos por direito autoral disponibilizados gratuitamente nos mais diversos sites de download, como também por meios legais, de tal forma que é possível encontrar pessoas dispostas a divulgar vídeos instrucionais por meio de sites como o YouTube ${ }^{1}$ ou mesmo discutir sobre teoria musical e técnicas de instrumentos em um dos diversos fóruns de discussão existentes.

Porém, por maior que seja o acervo de documentos educacionais na internet, tanto gratuitos como pagos, o desenvolvimento musical de um aluno depende também da interação musical com outras pessoas, e esse é um aspecto em que as opções oferecidas, apesar de existirem, não se popularizaram. Seria de se esperar que fosse possível criar pelo menos comunidades locais, onde a latência obtida estivesse abaixo do limiar de performance em conjunto e fosse permitido obter performances baseadas em um modelo de interação realística, mas isso não aconteceu.

\subsection{Soluções Alternativas}

\subsubsection{SoundJack}

Dentre os diversos softwares encontrados para a realização de performances musicais distribuídas, o Sound Jack pode ser considerado uma das soluções mais completas e adequadas para o usuário caseiro. Diversas decisões de arquitetura feitas no decorrer do projeto diminuem as dificuldades

\footnotetext{
${ }^{1}$ http://www.youtube.com/
} 


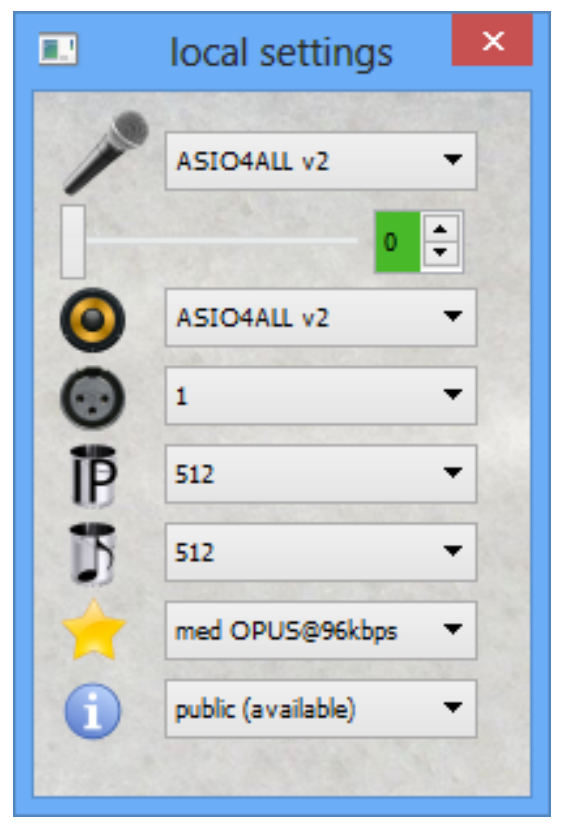

Figura 3.1: Janela principal do Sound Jack

a serem enfrentadas, como a possibilidade de se utilizar áudio compactado e a não exigência de um servidor central para seu uso. Porém, alguns inconvenientes foram encontrados durante o seu uso, principalmente devido a decisões tomadas pelo seu criador, Alexander Carôt. Durante alguns períodos, o autor retirou o acesso público às versões Linux do software e impossibilitou o uso da versão disponibilizada anteriormente devido à checagem de atualizações existente. Essa característica, associada à licença de código fechado faz com que seja interessante o desenvolvimento de softwares livres de finalidade semelhante.

Nas seções seguintes, as principais características do SoundJack serão detalhadas baseando-se na versão disponibilizada no dia 9 de outubro de 2012.

\section{Modo de Utilização}

Ao abrir o Sound Jack, o usuário encontrará a janela indicada na fig. 3.1, onde as principais configurações do software serão realizadas:

1. Escolha da entrada e saída a ser utilizada

2. Volume do áudio local e atraso desejado

3. Quantidade de canais a ser transmitida

4. Tamanho do pacote de rede

5. Tamanho do bloco de áudio

6. Codificador a ser utilizado

7. Modo de conexão

Entrada e saída de áudio Para acessar a placa de som nos diversos sistemas operacionais, o Sound Jack inicialmente utilizava o próprio JACK como API multiplataforma, como o próprio nome indica. Porém, versões mais recentes optaram por utilizar outras bibliotecas, como o RtAudio e, atualmente, o PortAudio, removendo a opção de se usar o JACK. Isso diminui a necessidade do usuário possuir outros softwares instalados (o próprio JACK), porém também reduz a flexibilidade do aplicativo, 
dificultando o roteamento do áudio para outros programas. Em plataformas Windows, é utilizado o padrão ASIO para acessar a placa de som do sistema, permitindo que baixas latências sejam obtidas, porém, é necessário que o computador possua um dispositivo compatível com tal especificação ou que seja instalado um driver genérico (tipicamente, utiliza-se o $\mathrm{ASIO}_{\mathrm{S}} \mathrm{ALL}^{2}$ ). Em sistemas Linux, o Sound Jack acessa a placa de som através do ALSA. Em ambas as plataformas, há a necessidade de acesso exclusivo ao dispositivo de áudio, impedindo que outros softwares emitam sons durante uma performance, o que poderia ser interessante para evitar a transmissão de sons indesejados de aplicativos que estejam sendo executados simultaneamente, mas, ao mesmo tempo, dificulta a integração com outros softwares de música, como o Pd.

A taxa de amostragem utilizada pelo Sound Jack é de $48 \mathrm{kHz}$, não havendo possibilidade para o usuário alterá-la. Essa escolha se deve ao codificador padrão do aplicativo, o OPUS, que foi desenvolvido com essa taxa de amostragem em mente. O OPUS também trabalha com os seguintes valores: 8 , 12,16 e $24 \mathrm{kHz}$, porém, para a utilização musical pretendida, a escolha mais adequada é a de 48 $\mathrm{kHz}$, por permitir que frequências de até $24 \mathrm{kHz}$ sejam representadas sem que ocorra rebatimento espectral, cobrindo assim toda a faixa de frequências audíveis pelo ser humano. Os outros valores disponíveis diminuiriam consideravelmente a qualidade do áudio transmitido pela rede, já que uma grande quantidade de harmônicos do sinal sonoro seria desprezada no processo de filtragem passa-baixas que ocorre antes da amostragem.

Modelo de Retorno Atrasado Para os casos em que o modelo de retorno atrasado é apropriado, o Sound Jack permite ajustar tanto o volume com que o áudio local será ouvido pelo músico quanto qual será o atraso realizado. As opções disponibilizadas vão de 0 a 40 e seus valores em milissegundos dependem do tamanho do bloco de áudio escolhido. Assim, as latências possíveis podem ser obtidas em milissegundos com a seguinte fórmula:

$$
d(y)=1000 \times y \times \frac{\text { tamanho do bloco }}{\text { taxa de amostragem }} \text {, em que } y=0,1, \ldots, 40 .
$$

Logo, os valores possíveis, dadas as características do SoundJack, variam de 0 a 426,67 ms.

Quantidade de canais É permitida apenas a transmissão monofônica ou estereofônica, o que é adequado para o uso em performances musicais distribuídas domiciliares.

Tamanho do pacote de rede Cada pacote de rede pode conter 128, 256 ou 512 amostras de áudio com a restrição de que esta quantidade seja maior no pacote de rede do que no bloco de áudio da placa de som. O valor escolhido para esta configuração afetará tanto a latência da transmissão quanto a largura de banda utilizada pelo software. Quanto maior o tamanho do pacote de rede, maior será a latência e menor será o uso de banda já que a quantidade de amostras de áudio que será enviada no pacote de rede fará com que o Sound Jack precise daquela quantidade de amostras ser disponibilizada pela placa de som, o que levará mais tempo. Um maior número de amostras por pacote fará com que menos pacotes sejam enviados por segundo, diminuindo ligeiramente o overhead de transmissão dos cabeçalhos de cada pacote.

Tamanho do bloco de áudio Pode ser configurado para 64, 128, 256 ou 512 amostras de áudio. Essa configuração e a do tamanho do pacote de rede estão bastante interconectadas e afetam essencialmente os mesmos aspectos de latência e largura de banda. Uma característica do Sound Jack é não permitir que os blocos de áudio sejam divididos em diversos pacotes de rede, embora seja possível agrupar vários deles em um mesmo pacote de rede.

\footnotetext{
${ }^{2}$ http://www.asio4all.com/ - Acessado em dezembro de 2012.
} 


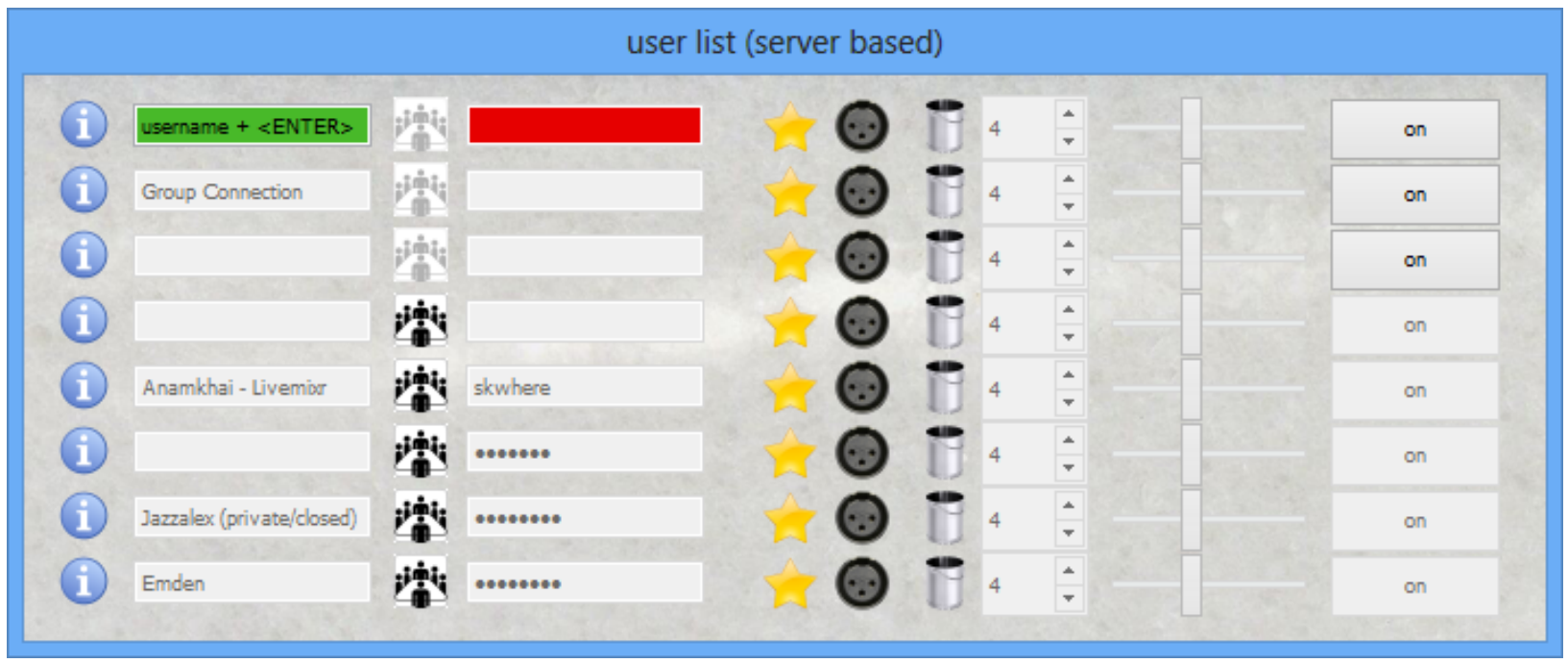

Figura 3.2: Janela de conexão automática do Sound Jack

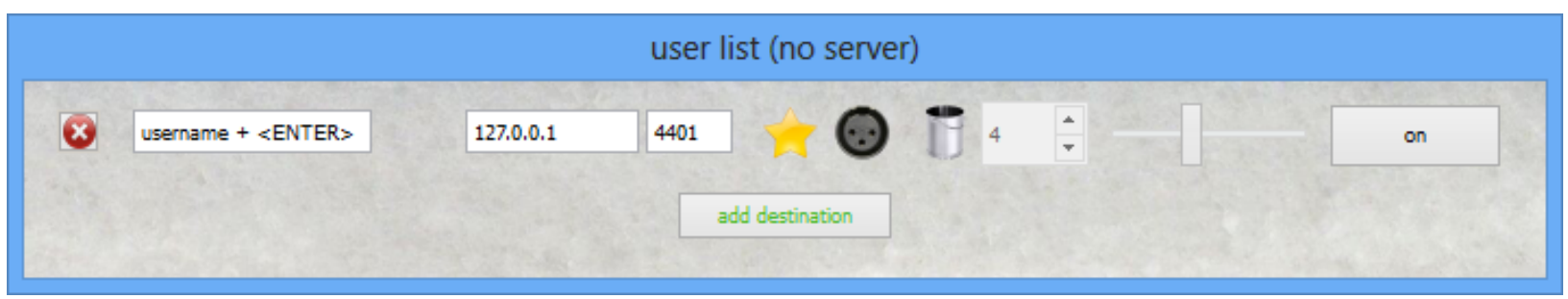

Figura 3.3: Janela de conexão manual do SoundJack

Codificação As opções disponíveis são de 48, 96 e 192 kbps ao se usar o codificador OPUS, porém a taxa de bits ao se usar codificação linear não é mencionada. Experimentalmente, foi observado que a resolução das amostras no modo linear é de 16 bits por amostra como será discutido na seção 4.1.

Modo de conexão O Sound Jack disponibiliza duas alternativas: conexão automática ou manual. Na conexão automática (fig. 3.2), o programa se conecta a um servidor pré-estabelecido hospedado pelo autor do software que auxilia na tarefa de localizar o usuário com o qual é desejado realizar a performance musical, funcionando como um ponto de encontro e diminuindo problemas de conectividade entre os participantes. Já o modo manual (fig. 3.3) permite que seja especificado o endereço IP ao qual o usuário deseja se conectar. Na tela de conexão ainda é possível especificar qual será a porta de destino, o tamanho do buffer de recebimento (em número de pacotes de rede) e a amplitude do sinal recebido. Para que o usuário possa estabelecer o tamanho ideal do buffer, o spinbox utilizado para a configuração possui dois estados indicativos: verde quando o tamanho é suficiente para que a reprodução do áudio ocorra sem interrupções e vermelho quando estejam ocorrendo falhas no som. Assim, o usuário deve ajustar manualmente este valor para o menor possível no qual o spinbox mantenha-se constantemente verde.

\subsubsection{Skype}

O Skype é uma das plataformas mais populares ${ }^{3}$ de VolP e, apesar de não ser indicada para o uso em performances musicais distribuídas, é usada em alguns casos para tal finalidade. É interessante analisar a ferramenta sob o ponto de vista da utilização musical para que os pontos fracos e fortes do aplicativo sejam evidenciados em contraste aos softwares dedicados para a prática de performances musicais através da rede.

\footnotetext{
${ }^{3}$ Em janeiro de 2013 era possível observar mais de 45 milhões de usuários conectados simultaneamente, de acordo com informação dada pelo próprio software.
} 


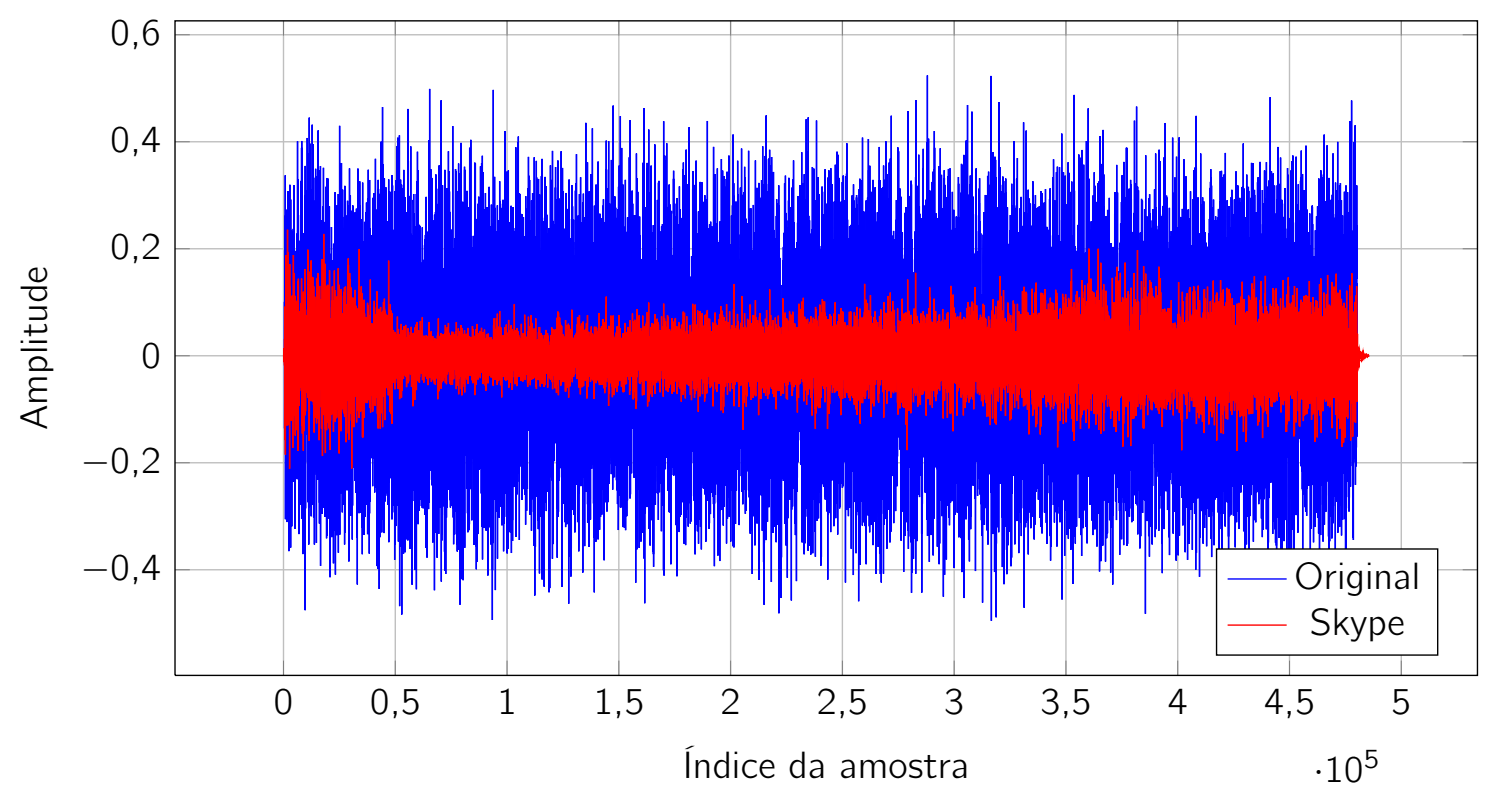

Figura 3.4: Controle automático de ganho no Skype

A principal diferença entre programas para VolP e para performances musicais distribuídas é certamente a maior tolerância à latência no uso não-musical. Enquanto o limite aceitável em aplicações musicais determinado pelo limiar de performance em conjunto é de $25 \mathrm{~ms}$, para VolP, a tolerância chega aos $200 \mathrm{~ms}$, podendo estender-se a até $250 \mathrm{~ms}$ dependendo da aceitação e adaptação dos usuários a problemas como o de interrupção de fala entre os participantes [Per99, MU01, VSMH02]. Com isso, é possível utilizar buffers maiores para evitar falhas na reprodução de áudio devido ao jitter da rede e/ou permitir conversas entre usuários muito mais distantes entre si do que é possível em uma performance musical distribuída.

Outra diferença é no aspecto da qualidade de áudio utilizada. O ramo da codificação de voz se aproveita de diversos aspectos do trato vocal humano para obter um nível de compactação alto mantendo-se sua inteligibilidade. Assim, a largura de banda necessária para o uso em VolP tende a ser muito menor do que a exigida para performances musicais distribuídas, porém, a qualidade sonora, embora adequada para a transmissão de voz, não é suficientemente boa para transmissões musicais. No caso do Skype, apenas um canal de áudio é codificado utilizando preferencialmente o codec SILK, que limita-se a representar frequências de no máximo $12000 \mathrm{~Hz}$ (Hertz). Outras opções de codificadores possíveis são iLBC, iSAC, G.729, iPCM-wb, EG.711 (lei A ou $\mu$ ) e PCM (lei A ou $\mu$ ) [BMM $\left.{ }^{+} 08\right]$. É sugerido um mínimo de $30 \mathrm{kbps}$ de largura de banda disponível para chamadas de áudio, sendo 100 kbps o valor recomendado [Sky].

Além disso, alguns efeitos utilizados pelo Skype no sinal de áudio são bastante úteis no cenário da transmissão de voz, mas conflitam com o interesse de envio de áudio de alta fidelidade. Um controle automático de ganho é aplicado no som de entrada, para que o volume da voz esteja sempre dentro de um nível audível desejado. Isto é realizado monitorando-se a intensidade do sinal e alterando um fator de ganho que será multiplicado pela onda a ser transmitida. Assim, em uma conversa, há uma menor variação no volume, evitando que o usuário receba um sinal alto ou baixo demais. Em contrapartida, em uma performance musical muitas vezes é desejado um controle de dinâmica por parte do praticante para que ele consiga executar tanto notas piano quanto forte. Um exemplo do controle automático de ganho do Skype pode ser observado na fig. 3.4, em que um sinal contendo ruído branco é enviado e a forma de onda resultante claramente mostra a amplitude sendo inicialmente reduzida e, depois, aumentada progressivamente.

Outro efeito aplicado pelo Skype é a redução de eco: em um cenário de comunicação de voz através de computadores, é possível que o usuário não esteja usando um fone de ouvido ou headset e sim os alto-falantes do próprio computador. Isso causa problemas de retorno de áudio, onde o som 
proveniente dos alto-falantes acaba sendo capturado novamente pelo microfone e termina por ser reenviado para o usuário original e o processo passa a se repetir indefinidamente em ambas as partes. Para evitar que isso ocorra, um algoritmo de cancelamento de eco é aplicado automaticamente pelo software. Porém, esse tipo de processamento atenua as frequências que ele detecta como sendo eco, afetando a fidelidade sonora, sendo assim indesejado em performances musicais distribuídas.

A grande vantagem de ser um software com ampla base de usuários se dá no aspecto de sua conectividade. Quando um dispositivo está conectado à Internet atrás de firewalls e/ou NATs, a utilização de aplicações P2P se torna consideravelmente mais complicada, como discutido na seção 2.2. No pior dos casos, será necessário alguma máquina que atue como um intermediário para a comunicação, o chamado retransmissor. No caso do Skype, por ser um serviço completamente P2P (com exceção do servidor de autenticação de usuários), todos aqueles que estiverem conectados à rede do mesmo são possíveis candidatos para receber tal papel.

Sendo um software fechado, o Skype foi objeto de estudos para se entender o funcionamento do próprio aplicativo e da estrutura utilizada em sua rede [SW06, BS04, GD05, KBS08]. A rede do Skype é composta por dois tipos de nós: o hospedeiro comum e o super-nó. Um hospedeiro comum é o participante da rede que estiver conectado a um super-nó e tiver sido registrado pela única entidade centralizada da rede, o servidor de autenticação, responsável por armazenar os nomes de usuário e senhas, garantindo que todo nome de usuário é único e autenticando o acesso dele à rede. Todo nó da rede pode se tornar um super-nó desde que possua suficientes recursos computacionais disponíveis (poder de processamento e largura banda de rede) e um endereço IP público. A função do super-nó é atuar como um retransmissor e também manter um registro que indica a disponibilidade de outros usuários de forma distribuída, removendo esta responsabilidade do servidor de autenticação. Todo cliente do Skype precisa manter uma tabela contendo uma lista constantemente atualizada de IPs e portas de super-nós acessíveis, caso contrário torna-se impossível acessar a rede. Inicialmente esta lista é populada com cerca de sete endereços padrões, chamados de nós de bootstrap.

Ao se conectar ao servidor de autenticação, todo cliente descobre se sua máquina está atrás de um NAT e/ou de um firewall e armazena esta informação para utilizar a técnica mais adequada para efetuar uma conexão multimídia. Se ambos os usuários possuírem um IP público e não estiverem por trás de um firewall, todo o tráfego de voz é realizado através de uma conexão direta com o protocolo UDP entre as partes. Caso apenas um dos participantes esteja atrás de um NAT, a conexão será iniciada por este usuário, independentemente de quem tenha iniciado a chamada, aproveitando-se do fato que a outra parte possui um IP público disponível. Se ambos os participantes estiverem atrás um NAT, o Skype tenta atravessá-lo através da técnica de perfuração. Caso esta tentativa falhe, um terceiro usuário (um super-nó) conectado à rede é escolhido para atuar como um retransmissor, de forma semelhante ao protocolo TURN, recebendo e enviando os dados de voz para cada um dos participantes ainda através de uma conexão UDP. A existência de um terceiro elemento na transmissão poderia levantar problemas de privacidade para os usuários do Skype, porém todos os dados são transmitidos de forma encriptada, de forma a evitar preocupações deste tipo. No caso de ser impossível se obter um canal de transmissão UDP devido a algum firewall, o Skype permite que a conferência seja realizada através de uma conexão TCP.

Embora a existência de um nó que possa servir como um retransmissor seja de grande importância para evitar que a chamada de voz não falhe completamente entre os clientes, ela não é necessariamente a solução mais adequada no que diz respeito a performances musicais distribuídas. A introdução de um terceiro elemento ao invés de uma conexão direta entre as partes tem como ponto negativo o aumento da distância de transmissão a ser percorrida, influenciando a latência. Em [KBS08] foram realizados experimentos para medir diversas características dos nós retransmissores e, em média, o tempo de ida e volta de pacotes de rede até um nó desse tipo foi de 52,2 ms. Enquanto um aumento latência total do sistema no caso de transmissão de voz pode não ter grandes impactos na fluência de uma conversa já que as tolerâncias a atrasos são razoavelmente altas, chegando a até $200 \mathrm{~ms}$, no caso da prática de performances musicais, um aumento de latência desta ordem se torna bastante indesejado, sendo maior que o dobro do valor do limiar de performance em conjunto, e acabaríamos apenas prejudicando a sensação de interatividade entre os músicos participantes, provavelmente forçando-os a adotar um 
modelo de performance musical distribuída diferente do esperado.

Para lidar com a placa de som, o Skype não faz proveito de APIs de áudio de baixa latência, como o ASIO em Windows, o que novamente faz sentido já que existe uma tolerância maior para a latência em comunicações de voz. Caso uma API desse tipo fosse utilizada, o software precisaria de acesso exclusivo à placa de som, ocasionando maiores imprevistos para o usuário, que teria de instalar um driver ASIO já que o mesmo não é comumente presente em instalações não-profissionais e poderia encontrar dificuldades de obter o áudio já que o dispositivo poderia estar sendo utilizado por algum outro programa em modo exclusivo. Embora a latência seja maior ao se usar as APIs padrões do sistema operacional, ela é baixa o suficiente para esta aplicação, não ocasionando maiores problemas. Para performances musicais distribuídas, no entanto, o uso de uma API de baixa latência é fundamental para sua viabilização.

Em [SW06, WCHL09] é descrito o algoritmo de dimensionamento de buffer utilizado. Bastante simples, apenas utiliza uma fila de pacotes de rede em que os blocos de áudio vão sendo tocados conforme chegam, mesmo quando os pacotes estão fora de ordem. O tamanho do buffer utilizado tem entre 250 a $300 \mathrm{~ms}$ e, caso um pacote atrase mais do que $60 \mathrm{~ms}$ do que o esperado, ele é considerado perdido. Mesmo assim, caso tal pacote chegue após esse período, ele ainda assim é reproduzido. Diferentes valores de latência, jitter e perda de pacotes da rede não influenciam no tamanho do buffer do programa.

Dadas todas estas características, é possível observar como o Skype é um software completamente focado na transmissão de voz, com quase nenhuma flexibilidade que permita ao usuário obter uma boa experiência ao utilizar sua estrutura para a prática de performances musicais distribuídas. Caso existissem opções embutidas no programa para se ajustar os tamanhos de buffers, o codificador utilizado, a quantidade de canais e o uso de APIs de baixa latência, seria difícil considerar que houvesse a necessidade da existência de outros programas focados em performances musicais distribuídas. Seu grande ponto positivo é certamente o bom proveito que ele faz da sua grande base de usuários, fazendo com que seja muito difícil que hajam falhas para o início de uma conferência por utilizar vários nós de sua rede como retransmissores de dados. Mesmo que isso não seja uma solução ótima para as performances musicais distribuídas devido ao aumento de latência proporcionado, talvez seja mais interessante permitir que a performance seja realizada com uma latência não ideal do que proporcionar ao usuário um erro de conexão que impeça completamente o intercâmbio musical.

\subsubsection{JackTrip}

O JackTrip é uma alternativa de código aberto para a realização de performances musicais distribuídas. Desenvolvido em C++ utilizando o arcabouço Qt por Juan-Pablo Cáceres para o CCRMA, é uma opção viável para esse tipo de prática, apesar de não possuir nenhum tipo de facilidade para que usuários de Internet residencial consigam realizar uma performance. Suas características indicam se tratar de um software voltado principalmente para o uso em comunidades acadêmicas, em que o limite de largura de banda é alto o suficiente para o envio de um número alto de canais de áudio sem compactação e a conexão entre os locais estável o bastante para não se observar um grande número de pacotes perdidos nem um jitter muito alto. Além disso, por usar como API de áudio principalmente o JACK, é possível integrá-lo de forma bastante simples a outros softwares de produção musical.

Do ponto de vista da experiência do usuário, o JackTrip possui problemas, pois, apesar de funcionar corretamente em Windows, Linux e Mac OS, em sua página apenas está disponibilizado para download a versão compilada para sistemas da Apple, tendo o usuário que compilar manualmente caso deseje utilizá-lo em outros sistemas. Além disso, a versão disponibilizada para download está bastante desatualizada em relação ao código disponível em seu repositório. Para sistemas Linux, ainda é possível obter uma versão compilada através de aplicações como o apt-get em distribuições Debian, porém, assim como no Macintosh, a versão disponibilizada é antiga e com alguns bugs que dificultam sua utilização. Outro ponto que pode afastar alguns usuários é a ausência de uma interface gráfica, havendo apenas opções de linha de comando disponíveis.

Nesta seção, será apresentado um estudo das opções disponibilizadas pelo JackTrip e suas implica- 


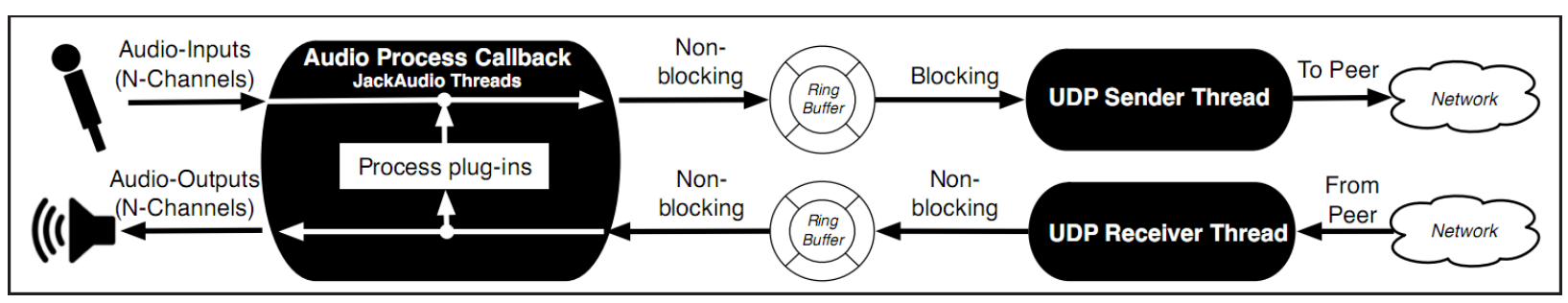

Figura 3.5: Visão geral do JackTrip [CC10]

ções no uso em performances musicais distribuídas caseiras baseando-se no código fonte da revisão 501 da SVN (Subversion), disponibilizado em sua página oficial ${ }^{4}$.

De forma bastante simplificada, o trabalho de qualquer software para transmissão de áudio pela rede se resume a capturar o sinal de áudio proveniente da placa de som, empacotá-los e enviá-los através de uma placa de rede. Simultaneamente, o processo inverso deverá ser efetuado, monitorando os pacotes de rede recebidos, extraindo as amostras de áudio deles e reproduzindo-os através do dispositivo de som. Com isso em mente, podemos identificar as principais classes usadas no JackTrip: AudioInterface, DataProtocol e aquela que promove a comunicação entre elas, o RingBuffer. Uma visão geral da estrutura proporcionada pela integração destes objetos pode ser observada na fig. 3.5.

\section{Audiolnterface}

A classe responsável por acessar a placa de som do computador é chamada de AudioInterface. Implementa duas subclasses especializadas para que seja possível utilizar tanto o JACK quanto o RtAudio. As duas APIs funcionam baseando-se no modelo de callbacks, em que uma função é registrada durante a inicialização do objeto para que esta seja chamada quando necessário. Da forma com a qual as placas de som funcionam, o período entre as chamadas de callback depende basicamente do número de amostras em cada bloco e da taxa de amostragem utilizada pelo dispositivo.

Por exemplo, se configurarmos a aplicação para usar blocos de 256 amostras a $44100 \mathrm{~Hz}$, a função será invocada a cada $256 / 44100 \approx 0,0058 \approx 5,80$ milissegundos. Isso implica em enfrentarmos uma latência já no processo de aquisição das amostras, ou seja, idealmente gostaríamos de obter o menor tamanho de bloco com a maior taxa de amostragem possível conjuntamente para minimizar a latência. Em geral, é necessário um meio termo entre os dois parâmetros para que o processo de obtenção do som transcorra sem problemas. Ao configurarmos o software para utilizar um tamanho de bloco muito pequeno e/ou uma taxa de amostragem muito grande sem que o hardware esteja preparado para isso, o que é observado é uma interrupção no fluxo de som, resultando em interrupções no áudio.

Assim, de tempos em tempos o áudio é capturado por esta classe e armazenado em um buffer circular que é compartilhado pela AudioInterface e pelo DataProtocol que as transmitirá pela rede. Simultaneamente, as amostras recebidas, que estavam em outro buffer circular, são lidas e reproduzidas. O código responsável pelo recebimento do áudio pela rede está exemplificado na listagem 1 (adaptado e traduzido para melhor formatação). O método computeProcessToNetwork efetua a operação inversa de forma semelhante. Ambos os métodos são chamados dentro do callback da API de áudio escolhida.

No caso do JackTrip, esta classe também é responsável por agrupar corretamente os canais de áudio para envio pela rede e alterar a resolução da amostra de acordo com o desejado pelo usuário. Ao enviarmos múltiplos canais de áudio, eles são agrupados sequencialmente em um mesmo pacote, precedidos de um pequeno cabeçalho contendo informações sobre a configuração utilizada pelo aplicativo. Considerando que $n_{i j}$ seja a amostra $i$ do canal $j$, a estrutura do pacote armazena o áudio da seguinte forma: $\left\{n_{00}, n_{10}, \ldots, n_{i 0}, n_{01}, n_{11}, \ldots, n_{i 1}, n_{02}, \ldots, n_{i j}\right\}$. Uma alternativa, não implementada, seria intercalar os canais de áudio fazendo com que a estrutura passasse a ser $\left\{n_{00}, n_{01}, \ldots, n_{0 j}, n_{10}, n_{11}, \ldots, n_{1 j}, n_{20}, \ldots, n_{i j}\right\}$. Maiores detalhes sobre as diferenças introduzidas por essa estrutura serão discutidas na seção 3.3.

\footnotetext{
${ }^{4}$ http://code.google.com/p/jacktrip/ - Acessado em janeiro de 2013.
} 


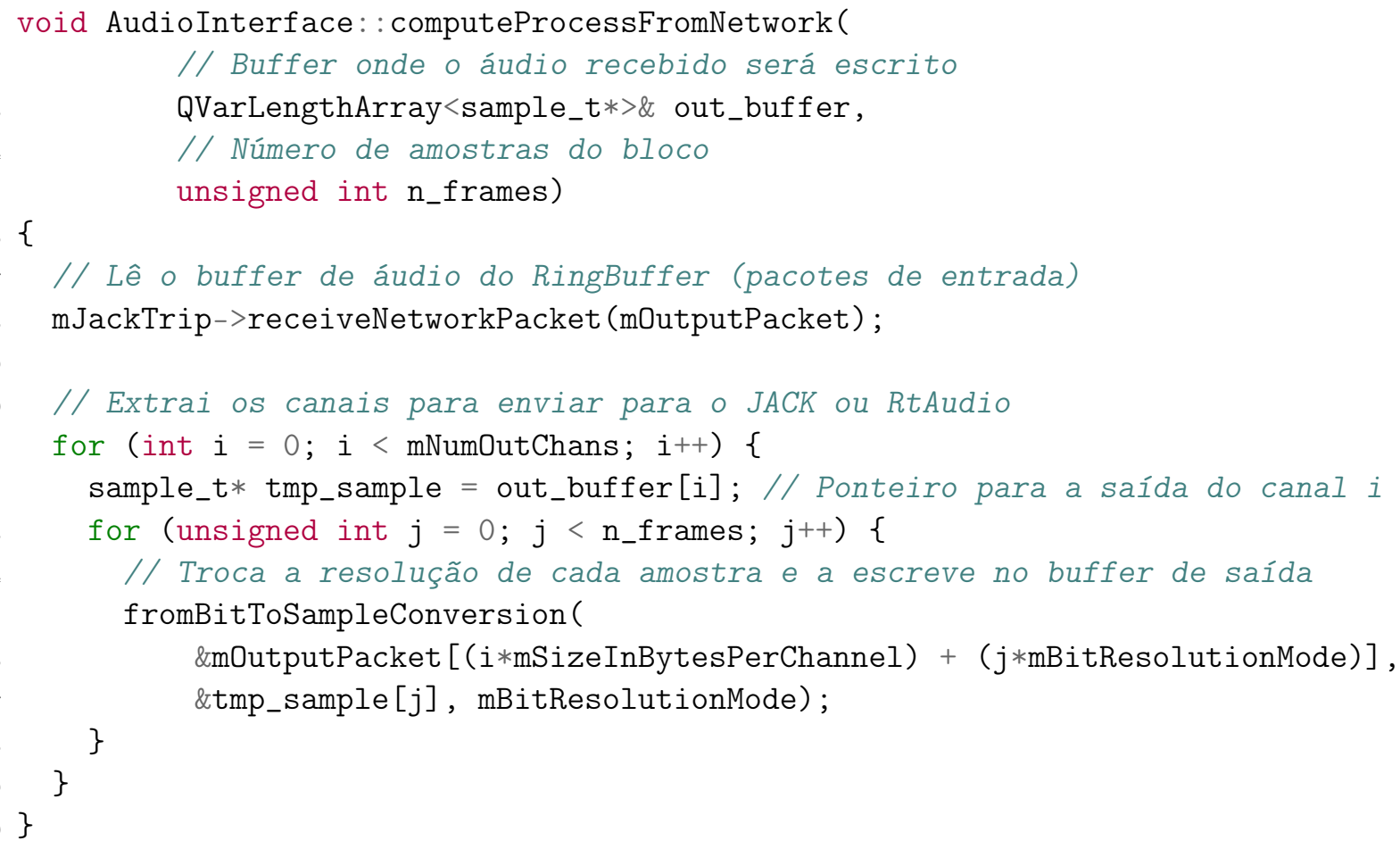

Listagem 1: Método de recebimento de pacotes de áudio para a rede

O servidor de áudio JACK trabalha apenas com amostras de ponto flutuante de 32 bits, exigindo uma grande largura de banda para sua transmissão. O JackTrip permite alterar a quantidade de bits utilizada em cada amostra para diminuir o uso de largura de banda, num processo chamado de requantização. As opções disponibilizadas pelo JackTrip são de 8, 16, 24 e 32 bits. Embora o RtAudio trabalhe nativamente com estes valores (além de outros formatos como amostras de ponto flutuante de 64 bits), no JackTrip a API sempre é inicializada no mesmo formato utilizado no JACK, facilitando o tratamento das amostras de áudio dentro da aplicação.

Para a conversão entre as resoluções de amostra, os métodos fromSampleToBitConversion e fromBitToSampleConversion são aplicados para converter de amostras de 32 bits para qualquer outro valor suportado e vice-versa. Amostras de 32 bits de ponto flutuante possuem valores limitados entre -1 e 1 . No caso de 8,16 e 24 bits, os valores das amostras são números inteiros que variam entre $-2^{b-1}$ e $2^{b-1}-1$, sendo $b$ o número de bits na amostra.

Para a conversão entre ponto flutuante e valores inteiros no caso de 8 e 16 bits, um método ingênuo é utilizado, onde apenas é aplicada a seguinte fórmula para que as escalas se tornem proporcionais: $\left\lfloor n \times 2^{b-1}\right\rfloor, n \in[-1,1]$. Infelizmente, o cálculo efetuado não leva em consideração o fato da escala ser assimétrica, podendo resultar em uma amostra de 8 bits contendo o valor 128, valor que ultrapassa o limite representável por um byte com sinal, acarretando em problemas de overflow e obtendo, na realidade, o valor -128 , invertendo o valor real da amostra (evidentemente um bug). No caso da requantização para 24 bits, o método utilizado é outro, exibido na listagem 2.

\section{DataProtocol}

A classe DataProtocol é responsável pelo envio e recebimento de dados pela rede. No JackTrip, apenas o protocolo UDP está implementado, através da subclasse UdpDataProtocol. Duas threads são utilizadas, uma para cada sentido de comunicação. Embora o arcabouço Qt ofereça algumas facilidades para se lidar com a rede, parte do código da classe é feito diretamente através de programação de sockets, pois, por termos duas threads rodando simultaneamente em uma mesma porta UDP, é necessário alocar separadamente os recursos da porta para recebimento em uma thread e envio em 


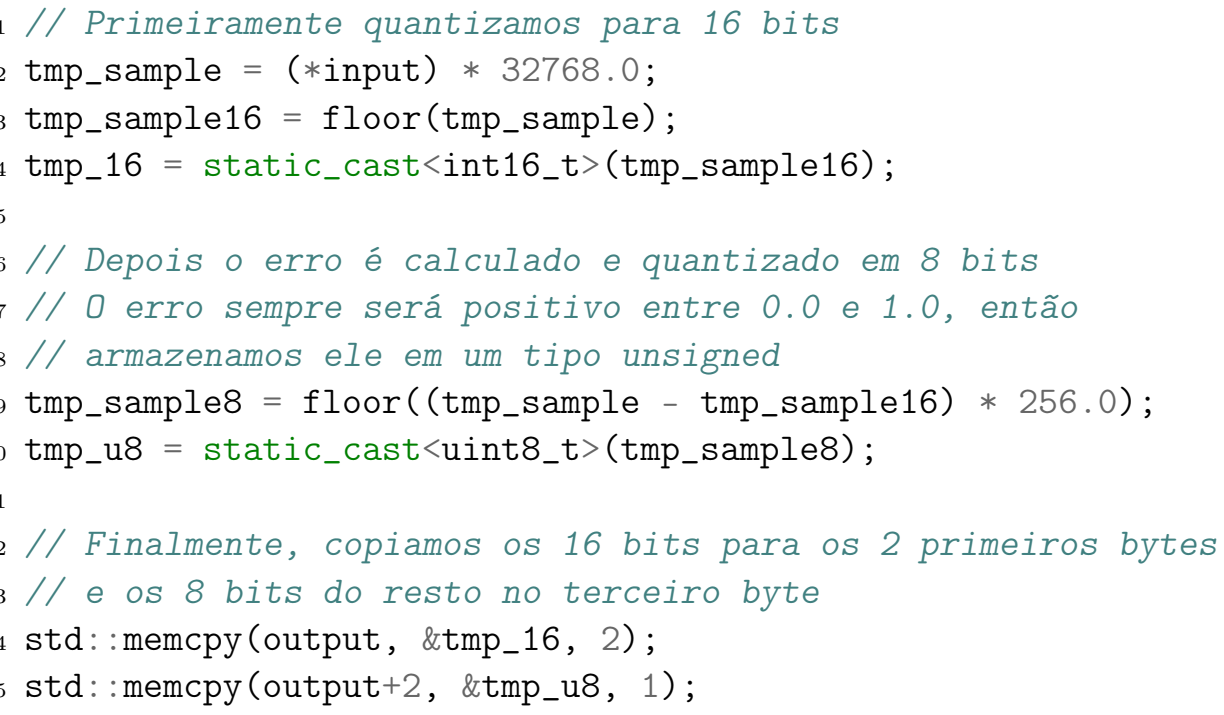

Listagem 2: Algoritmo para quantização em 24 bits

outra.

Além disso, a implementação não se aproveita dos recursos de sinais e slots oferecidos pelo Qt, implementando um laço infinito dentro do método run onde a thread é bloqueada enquanto aguarda a chegada de um pacote pela rede ou de um bloco de áudio da placa de som. Grande parte da comunicação entre objetos dentro do Qt se dá através de sinais e slots, em que um objeto pode emitir sinais e qualquer outro objeto que esteja interessado neste sinal pode conectar a ele um método (o slot) que será executado toda vez que o sinal for emitido. Outra possibilidade é conectar um sinal a outro, fazendo uma cadeia de sinais a serem emitidos. Assim, caso fosse utilizada a solução dada pelo arcabouço utilizado, a classe QUdpSocket, o próprio Qt emitiria um sinal indicando que haveria um novo pacote para ser lido pelo processo.

Dois modos de conexão são possíveis: servidor e cliente. As diferenças entre os modos são poucas, resumindo-se somente à inicialização da conexão. Caso o JackTrip seja inicializado em modo servidor através do comando jacktrip -s, o processo abre um socket na porta 4464 do protocolo UDP e fica aguardando a chegada de um pacote de algum cliente. Assim que é recebido qualquer pacote, o IP e porta de origem do pacote são obtidos e o servidor passa a enviar pacotes de áudio para esse endereço. Se iniciado em modo cliente (jacktrip -c <IP de destino $>$ ), o processo passa imediatamente a enviar pacotes de áudio pela rede para o destino, indefinidamente, enquanto aguarda a chegada de pacotes vindos da outra parte. Devido às características desta conexão, não é necessário que as partes sejam iniciadas como servidor-cliente, podendo se conectar mesmo que ambos os participantes abram o JackTrip em modo cliente, desde que os endereços IPs utilizados estejam corretos. É importante notar que cada processo só faz uma ligação ponto-a-ponto, caso o usuário deseje realizar uma performance musical distribuída com mais participantes, pode-se simplesmente abrir múltiplos processos (em portas diferentes) e realizar a conexão, porém nenhuma forma de sincronia será aplicada entre os processos, podendo ocasionar problemas se, por exemplo, a rota para uma das partes for consideravelmente mais longa (maior latência) em relação às outras.

Não está implementada nenhuma forma para auxiliar a conexão entre as partes, não havendo nenhum tipo de servidor centralizado que funcione como ponto de encontro, como implementado no SoundJack, ou um algoritmo de descoberta de nós como existe no Skype. Então, para que qualquer conexão ocorra, algum outro meio de comunicação deverá ser estabelecido externamente, de forma que seja possível ao menos divulgar a qual IP a conexão será feita.

Durante o envio e recebimento dos pacotes, esta classe também implementa um método de redundância de informação bastante simples para que se diminua a quantidade de falhas no áudio, 
dado que haja suficiente largura de banda disponível. A critério do usuário, é possível adicionar ao pacote de rede sendo enviado informação de pacotes passados para que, caso haja perda ou troca de ordem dos pacotes de rede, seja possível com estes dados redundantes corrigir estas ocorrências e evitar que o usuário sofra com interrupções na reprodução do áudio.

O algoritmo implementado simplesmente adiciona ao pacote de dado $d_{n}$ todo o áudio encontrado no pacote de dado $d_{n-1}$. O método de envio de áudio exemplificado na listagem 3 mostra o algoritmo utilizado, enquanto o código na listagem 4 ilustra o processo ao ocorrer uma falha no recebimento de algum dos pacotes.

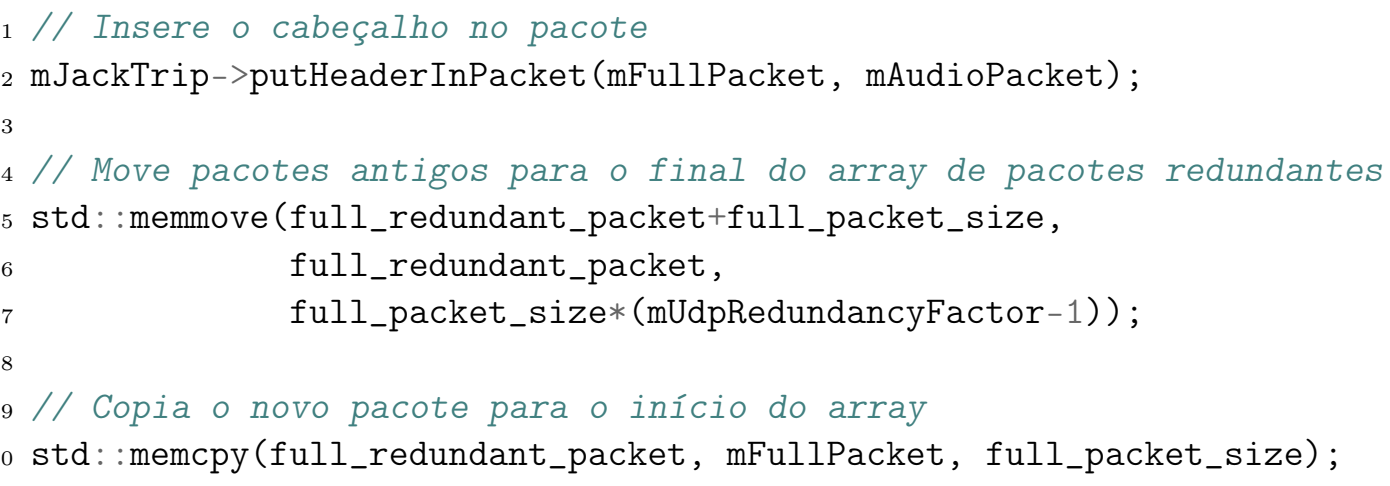

Listagem 3: Formação de pacotes com redundância

\section{RingBuffer}

Para que exista alguma integração entre a AudioInterface e o DataProtocol, é necessário haver algum buffer em que ambos os objetos possam ler e escrever dados. Esta é a principal função da classe RingBuffer, que implementa uma fila circular. Duas instâncias existem em um processo do JackTrip, uma em que a AudioInterface escreve e o DataProtocol lê e outra em que ocorre o inverso.

Quatro métodos são disponibilizados para interagir com instâncias desta classe:

\section{- insertSlotBlocking}

Insere um bloco de dados se houver espaço disponível no buffer. Caso o mesmo esteja lotado, bloqueia o processo e o libera apenas quando houver espaço livre. Este método não é utilizado por nenhuma das classes do JackTrip.

- readSlotBlocking

Lê um bloco de dados se o buffer não estiver vazio. Caso esteja vazio, bloqueia o processo enquanto não houver dados a serem lidos. É utilizado para o envio de pacotes para a rede, bloqueando a thread responsável pelo envio de áudio enquanto as amostras não são disponibilizadas pela AudioInterface.

\section{- insertSlotNonBlocking}

Insere um bloco de dados no RingBuffer. Caso não haja espaço disponível, metade do buffer é descartado e os dados desejados são escritos. Este método é usado em duas ocasiões: quando a AudioInterface deseja escrever no RingBuffer a ser lido pela thread do DataProtocol e quando o áudio proveniente da rede está sendo escrito no buffer que será lido pela AudioInterface. No primeiro caso, raramente ocorrerá algum problema de esgotamento de buffer já que se trata de um processo que ocorre localmente e que, assim que os dados são inseridos no buffer, são imediatamente lidos pela thread de envio pela rede que estava bloqueada com o método readSlotBlocking. No último caso é possível que aconteça um 


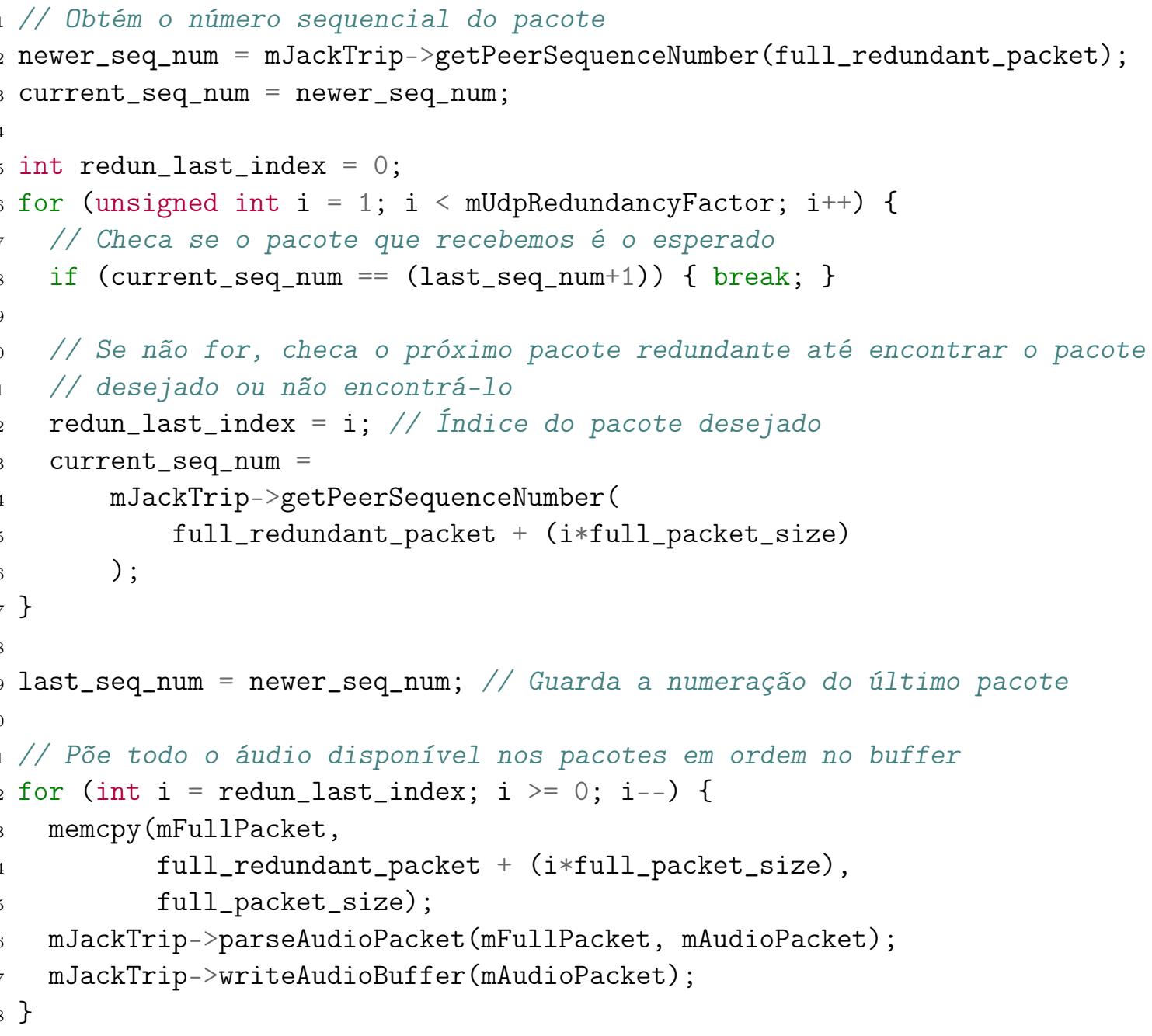

Listagem 4: Tratamento de falhas no recebimento de pacotes com redundância

acúmulo de pacotes atrasados na rede que necessitem de mais espaço do que o buffer suporta, fazendo sentido descartar uma quantidade razoável de pacotes para que o problema não ocorra frequentemente e para que a latência final obtida diminua.

\section{- readSlotNonBlocking}

Lê um bloco de dados do RingBuffer. Caso não haja nenhum dado para ser lido, é devolvido um bloco de áudio repleto de silêncio ou o bloco de áudio anterior ao atual. Este método é utilizado pela Audiolnterface quando o callback é executado e precisa de alguma informação para ser reproduzida pela placa de som. Infelizmente, nem sempre é possível ter a informação disponível justamente devido a atrasos, variações e perdas ocasionadas pela rede. A função do buffer é justamente evitar ao máximo que isso ocorra, porém, quando não houver outra opção e não houver dados para serem reproduzidos durante o callback, o JackTrip dispõe das duas alternativas mencionadas anteriormente.

Uma observação importante a respeito da implementação do JackTrip diz respeito justamente à manipulação dos buffers. Embora eles possuam um tamanho ajustável pelo usuário através de um parâmetro de linha de comando, o usuário não tem a possibilidade de alterar a posição inicial dos ponteiros de leitura e escrita do RingBuffer. Assim, ao abrir o processo, a diferença entre os ponteiros é de metade do tamanho do buffer. Porém, ao ocorrer um esvaziamento de buffer, o JackTrip não restaura este posicionamento, e sim passa a reproduzir os pacotes conforme chegam, na prática, 
anulando a funcionalidade deste RingBuffer. Embora possa parecer algum tipo de bug no código, isto é descrito em [CC10] como sendo parte do procedimento quando ocorre esvaziamento de buffer, tratando-se verdadeiramente de uma decisão de implementação.

Este comportamento se torna mais crítico ainda quando o processo é aberto em modo cliente, pois o callback da AudioInterface e a thread do DataProtocol passam a ler e escrever neste buffer imediatamente, mesmo sem haver dados sendo recebidos pela rede, esgotando e inutilizando completamente o RingBuffer. No caso do modo de servidor, a thread e o callback só são inicializados após o primeiro pacote ser recebido, fazendo com que o problema não seja tão evidente, porém ainda passível de ocorrer.

\section{PacketHeader}

O JackTrip possui um pequeno formato de cabeçalho de pacote para uso tanto durante o início da conexão quanto durante a transmissão. O formato utilizado pelo programa está definido na classe PacketHeader.

Uma limitação do aplicativo é a necessidade de todas as partes envolvidas possuírem exatamente a mesma configuração (com exceção de parâmetros como tamanho de buffer, por exemplo). Isso é necessário devido ao procedimento de inicialização das estruturas de dados utilizadas no JackTrip, como o RingBuffer. Assim, este cabeçalho é necessário para que seja possível garantir que as configurações utilizadas são as mesmas para todos.

O cabeçalho utilizado pode ser observado na listagem 5 .

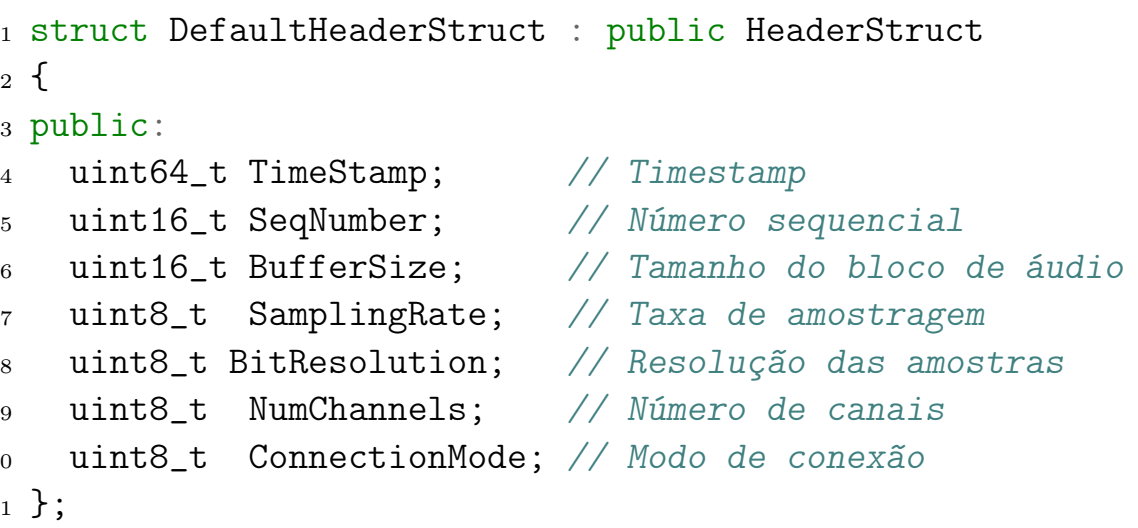

Listagem 5: Formato do cabeçalho

Quase todos os campos são auto-explicativos, o único que exige um maior esclarecimento é o ConnectionMode. Três possibilidades estão disponíveis no código: NORMAL, KSTRONG e JAMTEST. Este último não é documentado e poucas referências no código fazem sentido, fazendo jus a seu nome e provavelmente sendo um modo para testar alguma funcionalidade não terminada. O modo NORMAL indica que é um processo comum do JackTrip, enquanto o modo KSTRONG mostra que o usuário está tentando determinar o tamanho de buffer adequado para usar no aplicativo através de uma adaptação do algoritmo de síntese de Karplus-Strong que será detalhado mais adiante.

Outras opções disponibilizadas são a utilização de um tipo de cabeçalho completamente vazio (EmptyHeader), que diminui o overhead de cada pacote de rede, porém exige que os usuários assumam a responsabilidade de garantir que suas configurações são exatamente as mesmas para que a conexão aconteça com sucesso. Além disso, também é possível usar um tipo de cabeçalho desenhado especificamente para compatibilidade com o dispositivo de hardware jamLink ${ }^{5}$, criado com foco na realização de performances musicais distribuídas.

\footnotetext{
${ }^{5}$ http://www.musicianlink.com/ - Acessado em fevereiro de 2013.
} 


\section{Largura de Banda}

A largura de banda necessária para uso do JackTrip dependerá de diversas configurações de áudio. Cada pacote $p$ enviado pela rede terá um tamanho em bits de:

$$
\begin{aligned}
p=\text { tamanho do cabeçalho }+ & (\text { resolução da amostra } \times \text { tamanho do bloco } \\
& \times \text { número de canais } \times \text { redundância })
\end{aligned}
$$

A frequência de envio de pacotes $f$ é dada por:

$$
f=\frac{\text { taxa de amostragem }}{\text { tamanho do bloco }}
$$

Assim, a largura de banda $B$ exigida será de $B=f \times p$ bits por segundo. Por exemplo, para uma configuração de 16 bits por amostra, $44100 \mathrm{~Hz}$, estéreo, 512 amostras por bloco, sem redundância e que use 128 bits no cabeçalho (tamanho da versão testada), teremos que $B \approx 1422 \mathrm{kbps}$, no caso em que não há nenhum envio de informação redundante. Caso o usuário deseje utilizar o algoritmo de redundância implementado no JackTrip, pela fórmula pode-se observar que a largura de banda aumentará linearmente com o fator escolhido.

Outro ponto importante a respeito do tamanho do pacote de rede utilizado pelo JackTrip é que, por não haver nenhum tipo de fragmentação na camada da aplicação, estes pacotes se tornam excessivamente grandes e, mesmo podendo ser divididos pela camada IP, em casos extremos, pode haver a impossibilidade de transmissão de áudio, já que um pacote IP pode possuir no máximo 65535 bytes em sua totalidade. Considerando esta limitação e usando as configurações do exemplo anterior, poderíamos estabelecer uma performance musical distribuída de até 63 canais. Embora este seja um valor bastante alto, na realidade, existem outras limitações dependendo do sistema operacional utilizado. No Mac OS X, por exemplo, o maior tamanho possível para envio de um pacote UDP é de 9216 bytes. Desconsiderando todo tipo de cabeçalho envolvido na transmissão, poderíamos enviar no máximo 9 canais de áudio através do JackTrip, o que, dependendo do tipo de performance musical distribuída, pode sim ser um limitante.

\section{Determinando o Tamanho do Buffer}

Dimensionar corretamente o buffer para que exista um equilíbrio adequado entre a possibilidade de ocorrer falhas de som devido ao jitter e o desejo de obtenção de uma latência que não seja demasiadamente grande é um dos desafios enfrentados pelos usuários, já que esta tarefa acaba sendo delegada a eles em aplicações para performances musicais distribuídas, sendo que no JackTrip este parâmetro é ajustado durante a inicialização do software, não podendo ser alterado dinamicamente durante a execução.

Uma solução bastante interessante para este problema é adaptar um método de síntese de timbres de instrumentos de corda conhecido como Karplus-Strong [KS83] para que ele ilustre sonoramente o estado atual da rede [CWW02].

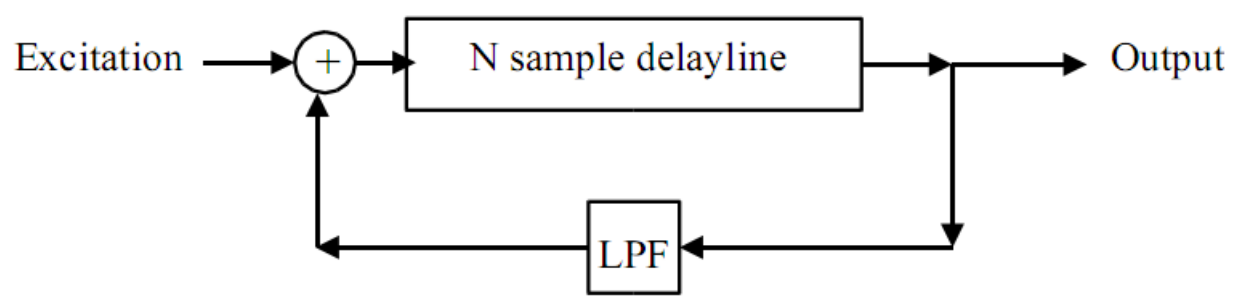

Figura 3.6: Diagrama do Karplus-Strong [CWWO2]

O modelo de Karplus-Strong, ilustrado na fig. 3.6, simula o som de instrumentos de corda através 
de um bloco de áudio inicial ruidoso (excitação), com tamanho dado pelo período associado à frequência sonora desejada, que será iterado num processo cíclico de atraso, filtragem e realimentação, até que a própria filtragem passa-baixas resulte no decaimento do som por completo.

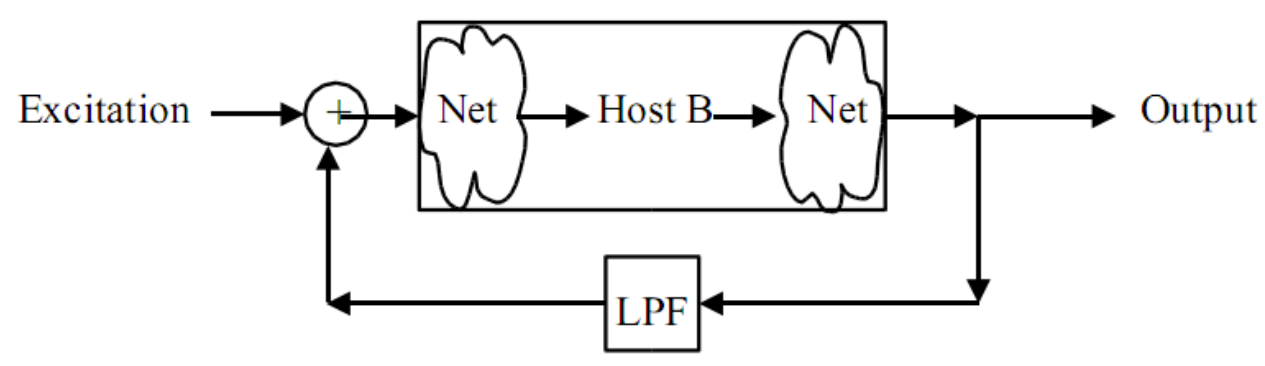

Figura 3.7: Diagrama do SoundWIRE [CWW02]

O método para ajustar o tamanho do buffer chamado SoundWIRE (Sound Waves on the Internet from Real-time Echoes) [CWW02] se baseia neste modelo, mas ao invés de utilizar uma versão atrasada do sinal por um meio local, ele se aproveita dos atrasos ocasionados pela própria rede para essa finalidade (fig. 3.7).

Assim, ao conectar-se a um servidor, este envia um sinal ruidoso que demorará o tempo da latência da conexão para chegar ao cliente, que reenvia o sinal para o servidor, onde o filtro passa-baixa será aplicado, repetindo o processo assim como no modelo de Karplus-Strong. O resultado deste procedimento é que o sinal ouvido pelo cliente dependerá das condições da rede e das configurações escolhidas para o tamanho do buffer, e terá uma peridiocidade relacionada à latência do ciclo completo. Quanto mais agudo o som, menor é a latência encontrada entre as duas partes, já que o atraso proporcionado pela rede e pelo tamanho do buffer será menor, diminuindo o período da onda e aumentando a frequência. As variações de latência (jitter) serão percebidas acusticamente como um vibrato (variações de frequência) no áudio recebido. Ao aumentar o tamanho do buffer, a som tornará-se mais grave, mas terá menos variações.

Logo, a fim de determinar o tamanho de buffer ideal para uma performance musical distribuída, a meta do usuário agora é encontrar o ponto em que o som seja o mais agudo possível, sem que haja muito vibrato. Este método torna-se muito mais intuitivo do ponto de vista musical do que a necessidade de se observar durante a performance musical se está havendo ou não muitas falhas no áudio transmitido.

Embora o JackTrip supostamente implemente esta técnica, não há nenhuma opção de linha de comando disponível para abrir um servidor neste modo. Existem menções no código ao Karplus-Strong através do já citado modo KSTRONG e da classe NetKS, porém ela apenas é instanciada dentro de trechos comentados, aparentemente para testes, sendo difícil que um usuário não-programador tenha acesso a esta funcionalidade.

\section{Considerações Finais}

O JackTrip é uma ferramenta razoavelmente simples para a realização de performances musicais distribuídas, tendo características não muito interessantes para o uso no caso doméstico, já que utiliza uma largura de banda bastante alta e sua implementação de buffers para diminuir o impacto do jitter tem características indesejadas. Ao mesmo tempo, sua grande flexibilidade de opções fazem com que, quando utilizado em redes de alta velocidade como as existentes em instituições acadêmicas, sua performance seja adequada e permita que haja um uso de um número muito maior de canais do que o permitido em aplicações como o Sound Jack e o Skype, apesar de ainda possuir algumas limitações neste sentido. Outro problema do ponto de vista da experiência do usuário é a completa ausência de uma interface gráfica e a necessidade de ter de recorrer a meios externos para que a conexão possa ser realizada, por não existir nenhum meio através da própria aplicação de encontrar usuários utilizando o software. 
Por outro lado, o fato do JackTrip ser um software livre torna possível modificar todas estas características, tornando-o uma aplicação mais completa. Na seção seguinte, discutiremos todas as modificações realizadas no JackTrip, a fim de transformá-lo em uma opção mais atraente para performances musicais distribuídas.

\subsection{APls de Áudio}

Nesta seção será realizada uma descrição das APIs de áudio utilizadas pelos softwares SoundJack e JackTrip: o PortAudio, o RtAudio e o JACK.

\subsubsection{PortAudio}

O PortAudio ${ }^{6}$ é uma API proposta por Ross Bencina que implementa uma camada de abstração sobre as diversas APIs nativas disponibilizadas pelos sistemas operacionais Windows, Mac OS X e Linux/Unix, facilitando e estimulando o desenvolvimento de aplicações de áudio multiplataforma. São aceitas as seguintes APIs de áudio nativas:

\section{- Windows}

Windows Multimedia Extensions, DirectSound, Windows Driver Model/Kernel Streaming, Windows Audio Session APl;

\section{- Mac OS X}

CoreAudio e JACK;

\section{- Linux/Unix}

Open Sound System, Advanced Linux Sound Architecture e JACK.

Tanto a entrada quanto a saída de áudio podem ser utilizadas com diversos formatos de amostra: $8,16,24$ e 32 bits inteiros ou ainda 32 bits ponto flutuante. Quando lidando com múltiplos canais de áudio, estes podem estar intercalados ou não e o PortAudio automaticamente faz a conversão necessária.

A funcionalidade básica oferecida possibilita ao desenvolvedor enumerar quais são as APIs nativas disponíveis, quais os dispositivos de áudio e suas capacidades (taxas de amostragem e formatos aceitos) e a criação de fluxos que permitem ao programa enviar ou receber áudio dos dispositivos.

Para processar o áudio, além de um modelo de callbacks, também é possível utilizar um modelo síncrono de leitura e escrita: ao invés de registrar uma função que será chamada de tempos em tempos, pode-se chamar as funções $\mathrm{Pa}$ _WriteStream e Pa_ReadStream dentro de um laço para se interagir com o dispositivo de áudio.

\subsubsection{RtAudio}

O RtAudio ${ }^{7}$ é uma API desenvolvida por Gary P. Scavone que possui características muito semelhantes às do PortAudio, implementando uma camada que abstrai outras APls nativas dos sistemas operacionais Windows, Mac OS X e Linux. Apesar de implementar um subconjunto diferente de APIs nativas (suporta apenas DirectSound e ASIO em sistemas Windows, mas oferece também a opção de PulseAudio no Linux), oferece como vantagem em relação ao PortAudio uma menor dificuldade de integração a projetos de áudio, já que exige apenas a inclusão de dois arquivos de cabeçalhos e um arquivo contendo código fonte em $\mathrm{C}++$.

Além disso, a integração com sistemas Windows não possui outras dependências. Em comparação, o PortAudio exige que sejam instalados tanto o kit de desenvolvimento do DirectX quanto do ASIO,

\footnotetext{
${ }^{6}$ http://www.portaudio.com/ - Acessado em fevereiro de 2013.

${ }^{7}$ http://www.music.mcgill.ca/ gary/rtaudio/ - Acessado em fevereiro de 2013.
} 
que, embora sejam disponibilizados gratuitamente pela Microsoft e Steinberg, respectivamente, podem ser considerados como empecilhos para a utilização do PortAudio neste sistema.

\subsubsection{JACK}

$\mathrm{O} \mathrm{JACK}^{8}$, em contraste com as opções discutidas anteriormente, não é simplesmente uma abstração criada a partir das APIs disponibilizadas pelos sistemas operacionais, mas sim uma solução para um problema maior: o da conectividade de áudio entre programas.

Imagine um cenário em que existam diversas aplicações de áudio: um gravador multi-pistas, um sintetizador e um sequenciador, por exemplo, e existe o desejo de interligar estes três programas. Em sistemas Windows e Macintosh, a solução foi a criação de diversas aplicações monolíticas que agregavam muitas das funcionalidades desejadas pelos músicos e ofereciam a possibilidade de implementação de plugins que expandiam ainda mais as características oferecidas. Embora existam protocolos como o ReWire, desenvolvido através de uma parceria entre a Propellerhead e a Steinberg, que padroniza a transmissão de dados entre programas de áudio, muitas das aplicações desenvolvidas para estes sistemas ainda se baseiam no conceito de plugins. No caso do Linux, a solução proposta pelo JACK é semelhante ao ReWire, permitindo que os programas de áudio se comuniquem através de um padrão bem definido.

Ao contrário de outros servidores de áudio disponíveis para Linux, que utilizam um modelo onde a aplicação decide quando e o quê ela deseja reproduzir através do dispositivo de áudio e, com isso, dificultam a sincronização sonora entre aplicações distintas, o JACK utiliza o modelo de callbacks e tem como foco justamente possibilitar este tipo de sincronia entre os programas.

A abstração introduzida pelo JACK é mais ampla do que a das outras APIs discutidas anteriormente, já que, neste caso, as características do dispositivo de áudio sequer são mencionadas quando uma aplicação com suporte ao JACK é desenvolvida. Isso é possível pois, para o servidor de áudio, todas as amostras são representadas através de 32 bits ponto flutuante normalizados entre -1 e 1 e a quantidade de canais a serem disponibilizados independe da interface de áudio, já que estes canais podem ser conectados não só à placa de som, mas também a outras aplicações. A diferença na camada de abstração em que o JACK atua também pode ser observada na implementação para plataformas Windows, em que a comunicação com o dispositivo de áudio é realizada através da biblioteca PortAudio.

\section{Considerações Finais}

Um aspecto importante de ser discutido sobre estas APIs é a sua interação com o usuário final. Em termos gerais, o comportamento padrão de aplicações de áudio é de que elas sejam auto-contidas e monolíticas como já discutido, e, dado este paradigma adotado por grande parte destas aplicações, não é desejado que haja uma dependência de um servidor de áudio como o JACK tendo que ser executado paralelamente para o correto funcionamento de uma aplicação. Neste aspecto, implementações que utilizem APIs como o PortAudio e o RtAudio acabam por lidar diretamente com a configuração adequada do dispositivo de áudio, fazendo-o de forma transparente ao usuário, o que é o ideal do ponto de vista da usabilidade, já que pouca ou nenhuma configuração terá de ser realizada por ele.

Em contrapartida, a utilização do JACK aumenta a flexibilidade da aplicação, permitindo que ela possa ser usada em contextos para os quais ela não foi originalmente planejada. Imagine um cenário em que um guitarrista deseje tocar com um vocalista através da Internet e ele não possua nenhum tipo de pedal de efeitos. Uma possibilidade seria utilizar o próprio computador como um tipo de pedaleira digital, já que existem aplicações comerciais e livres com este propósito. No caso de projetos que implementem a API do JACK, nenhum tipo de modificação no software é necessária para que o guitarrista possa realizar a performance musical distribuída utilizando-se de efeitos, bastando estruturar o fluxo de áudio de forma que o sinal da guitarra passe pelo programa que aplique efeitos antes de ser transmitido pela rede. Já no caso em que a interface de áudio é utilizada diretamente através de APIs como o RtAudio e o PortAudio, a única solução possível é implementar dentro da própria

\footnotetext{
${ }^{8}$ http://jackaudio.org/ - Acessado em fevereiro de 2013.
} 
aplicação algum sistema de plugins que seja compatível com o programa que o guitarrista planeja usar, nos padrões VST (Virtual Studio Technology) ou LADSPA (Linux Audio Developer's Simple Plugin $A P I)$, por exemplo. Imagine agora que os músicos envolvidos nesta performance musical distribuída hipotética também desejem gravar a performance digitalmente. Novamente, no caso do JACK, basta conectar um gravador no fluxo de áudio, ao passo que nas outras APls a própria aplicação terá de ser modificada para cobrir este caso de uso. Embora isto mostre uma vantagem significativa do uso do JACK, configurá-lo adequadamente exige do usuário um maior conhecimento sobre o funcionamento da cadeia de áudio dentro de um computador.

Também é importante observar que, dada a grande quantidade de APIs nativas dos sistemas operacionais existentes, muitas delas acabam criando conflitos umas com as outras e dificultam o uso de dispositivos de áudio, embora isto não seja um problema relacionado às APIs discutidas nesta seção. Por exemplo, padrões como o ASIO exigem acesso exclusivo à placa de som, impedindo que outras APIs consigam acessar a interface, já que ela é considerada como em uso ou ocupada. De forma similar, o problema inverso pode ocorrer, já que uma aplicação pode estar utilizando a placa de som através da API padrão de áudio do Windows e, quando o usuário tentar acessar o mesmo dispositivo através do ASIO, a tentativa acaba falhando pois não foi possível obter a interface de modo exclusivo. Como há uma grande diferença de latência entre estas duas APIs, este tipo de dificuldade acaba sendo bastante prejudicial à popularização de aplicações que exijam baixas latências, pois o usuário acaba enfrentando dificuldades no uso dos aplicativos, muitas vezes não conseguindo fazer com que a aplicação emita ou receba nenhum tipo de áudio.

\subsection{JackTripMod}

O JackTripMod é o projeto desenvolvido durante este trabalho de mestrado, baseando-se no código do JackTrip, como o próprio nome indica, com a finalidade de adicionar ao projeto original características mais interessantes para o usuário caseiro, mantendo toda a sua flexibilidade para usuários em geral. Uma parte das funcionalidades adicionadas simplesmente o coloca em posição de igualdade com outros softwares semelhantes, enquanto outras trazem ideias diferentes para solucionar alguns problemas enfrentados na área das performance musical distribuída.

Essencialmente, as novas funcionalidades implementadas estão listadas a seguir:

- Adição da opção de codificação compactada com o CELT;

- Implementação do Modelo de Retorno Atrasado;

- Criação de uma interface gráfica para o usuário;

- Integração com o software de comunicação instantânea Pidgin para o estabelecimento de conexões;

- Possibilidade de efetuar performances musicais distribuídas com configurações distintas;

- Múltiplas conexões entre usuários;

- Novos métodos de gerenciamento de buffer;

- Fragmentação de pacotes na camada da aplicação.

Nas próximas seções, um maior detalhamento de cada um destes itens será dado.

\subsubsection{Codificação de Áudio}

O principal problema do JackTrip original para seu uso na internet comercialmente disponível no Brasil é o seu uso de codificação PCM sem nenhuma opção de compactação para a transmissão de 
áudio. Isso faz com que a exigência de largura de banda para se obter alta qualidade atinja valores inviáveis dadas as baixas taxas de upload obtidas por usuários domésticos.

A resposta mais óbvia para este problema é o uso de algum tipo de compactação de áudio, já que técnicas de codificação como o MP3 e o AAC são bastante populares e conseguem atingir uma taxa de compactação bastante alta mantendo grande parte da qualidade original do áudio, em muitos casos fazendo com que o arquivo final possua um décimo de seu tamanho original em PCM. Uma taxa comumente utilizada na codificação MP3 e AAC é de 128 kbps para gravações estéreo que possuem qualidade subjetiva próxima à do $C D$, que utiliza $1411 \mathrm{kbps}$. Porém, o uso destes padrões de codificação não é viável em performances musicais distribuídas, pois em ambos os casos existe uma latência algorítmica razoavelmente alta para aplicações em tempo real. Esse tipo de atraso faz parte da própria estrutura do compactador, muitas vezes por haver uma necessidade de acumular um certo número de amostras para que seja possível analisar o sinal de forma a obter o detalhamento desejado para processá-lo, sendo esta latência portanto impossível de ser eliminada pela troca de hardware por um outro de maior poder de processamento.

$\mathrm{Em}$ [LSG+ 04], foi realizado um estudo sobre as latências observadas em alguns tipos de compactação, obtendo valores de 54 a 142 ms de atraso no caso do MP3 e 20 a 361 ms para o AAC com taxas de amostragem de $48000 \mathrm{~Hz}$. A faixa observada no caso do AAC é maior pois é possível escolher alguns modos distintos em que o usuário decide se deseja uma latência menor ou uma eficiência maior na compactação. Assim, para que seja possível realizar uma performance musical distribuída dentro do limiar de performance em conjunto, apenas o modo AAC-LD se mostra adequado para a tarefa, com uma latência algorítmica de 20 ms diante dos 25 ms desejados.

Porém, é possível encontrar codificadores com uma latência menor do que a proporcionada pelo AAC-LD. O principal exemplo desta categoria é o CELT, que tem o mérito de disponibilizar um método de compactação de áudio com alta qualidade, latência de 9 ms e taxa de bits de 64 kbps por canal.

O CELT é um codificador desenvolvido pela Xiph. Org ${ }^{9}$, criadora de diversos formatos abertos como o codificador de voz Speex ${ }^{10}$, baseado em CELP (Code-Excited Linear Prediction ou Predição Linear Excitada por Códigos) [SA85], e os compactadores de alta qualidade com perdas Vorbis ${ }^{11}$ e sem perdas FLAC ${ }^{12}$.

Ele é baseado em codificação por transformadas, usando a MDCT (Modified Discrete Cosine Transform ou Transformada Discreta de Cosseno Modificada) para realizar a codificação no domínio da frequência. As taxas de bits sugeridas para alta qualidade são de cerca de $48 \mathrm{kbps}$ para sinais de voz e de 64 kbps para músicas. Isto resulta em uma resolução de 1,08 bit/amostra para voz e em torno de $1,45 \mathrm{bit} /$ amostra para músicas com uma taxa de amostragem de $44,1 \mathrm{kHz}$. O codificador pode ser configurado para usar uma taxa de amostragem de 32 até $96 \mathrm{kHz}$, taxa de bits partindo de $32 \mathrm{kbps}$ e blocos de áudio de 64 a 512 amostras, conseguindo assim atingir as baixas latências desejadas.

Um aspecto importante sobre o desenvolvimento recente do CELT é a sua combinação com o codificador proprietário do Skype, o SILK, padronizado pela norma RFC 6716 [VVT12] da IETF criando o OPUS. Sendo uma evolução do CELT, oferecendo uma especificação padronizada e uma opção mais adequada para a codificação de voz, seria natural pensar em implementar o OPUS no JackTrip, porém, durante seu desenvolvimento algumas taxas de amostragem deixaram de ser suportadas devido a otimizações realizadas com base em sinais de áudio amostrados a $48000 \mathrm{~Hz}$. Por exemplo, a taxa de $44100 \mathrm{~Hz}$, muito utilizada por ser o padrão do CD, não é mais considerada como uma opção para a criação do objeto de codificação do OPUS. Assim, caso o usuário desejasse utilizar esta taxa de amostragem, seria preciso efetuar o processo de reamostragem do sinal, o que introduziria mais um passo no processamento que poderia afetar tanto a qualidade de áudio negativamente quanto gerar um aumento na latência já que, ao reamostrarmos um sinal, é necessário filtrar algumas componentes espectrais a fim de evitar o rebatimento de frequências que resultaria em perda de qualidade do sinal. Mas ao realizarmos o processo de filtragem, estaremos adicionando latência ao sistema..

\footnotetext{
${ }^{9}$ http://www.xiph.org/ - Acessado em janeiro de 2013.

${ }^{10}$ http://www.speex.org - Acessado em janeiro de 2013.

${ }^{11}$ http://www.vorbis.com/ - Acessado em janeiro de 2013.

${ }^{12}$ http://flac.sourceforge.net/ - Acessado em janeiro de 2013.
} 


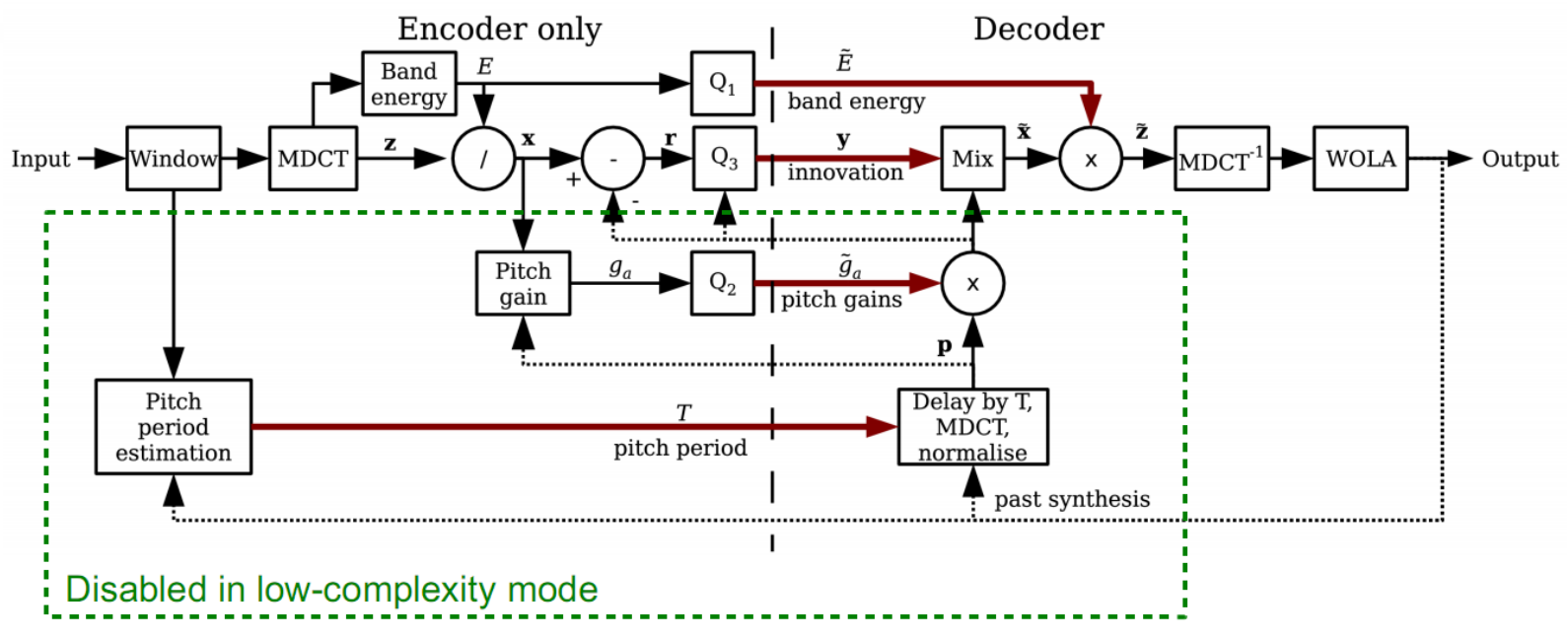

Figura 3.8: Estrutura do codificador CELT [VTO9]

Com isso, a implementação da versão original do CELT ainda se mostra uma escolha adequada e, com as modificações feitas no JackTrip para que o CELT seja utilizado como uma opção de codificação, a criação da funcionalidade para o uso do OPUS se torna bastante simples.

\section{Estrutura do Codificador CELT}

O funcionamento do codificador pode ser descrito da seguinte forma:

- O sinal de entrada é subdividido em blocos que vão para a MDCT;

- A saída da MDCT é agrupada de forma a se assemelhar às regiões críticas do ouvido;

- Cada banda é normalizada e tem sua energia transmitida separadamente;

- Os detalhes de cada banda são quantizados e transmitidos;

- Um preditor de longo prazo é usado opcionalmente para compensar a baixa resolução espectral obtida devido ao tamanho dos blocos de áudio utilizados no processo;

Um diagrama de blocos do codificador pode ser visto na fig. 3.8. Pode-se notar que o codificador inclui um decodificador também, já que alguns parâmetros de análise se utilizam do sinal decodificado para evitar a transmissão de informação lateral. No apêndice A, os processos realizados serão melhor detalhados.

\section{Integração do CELT com o JackTripMod}

Para o uso do CELT no JackTrip a principal modificação se deu na classe AudioInterface, que era responsável pela requantização das amostras PCM em sua versão original, além da comunicação com a placa de som. O processo foi abstraído para uma classe própria, a Codec, em que os métodos encode e decode servem como uma camada de abstração para a realização das chamadas às bibliotecas dos codificadores, transformando um bloco de áudio proveniente do JACK no formato de pacote utilizado pelo padrão implementado e vice-versa.

A classe base Codec implementa a funcionalidade original do JackTrip, requantizando amostras de 32 bits para 8, 16 ou 24 bits e também realizando o processo inverso. Para o funcionamento do CELT foi criada a subclasse CodecCelt, que inicializa adequadamente o codificador e faz chamadas às funções celt_encode_float e celt_decode_float para o processamento do sinal de áudio. 


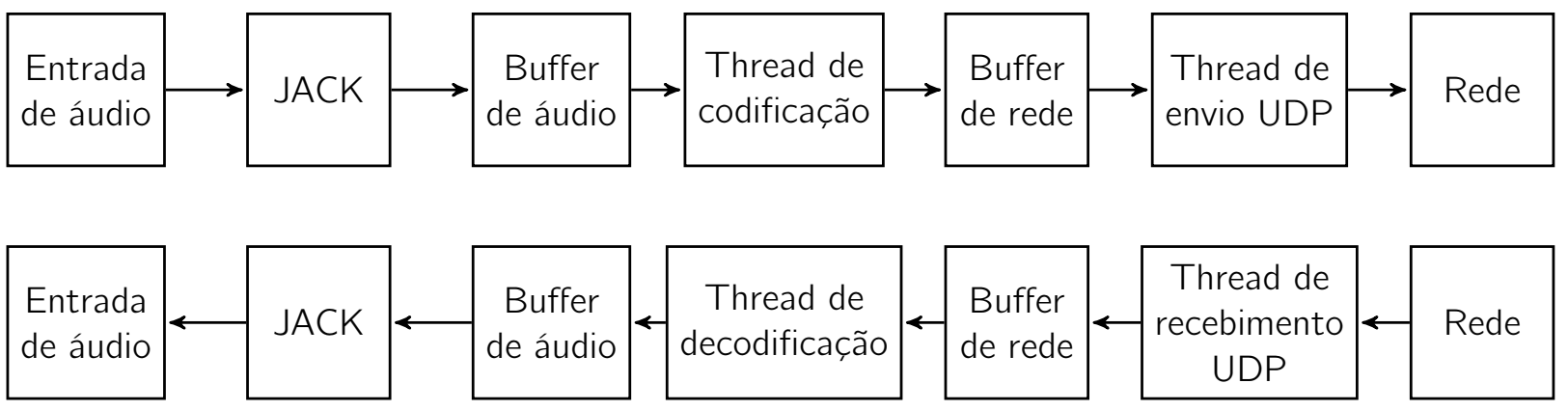

Figura 3.9: Visão geral do JackTripMod

Nativamente, o CELT suporta apenas sinais monofônicos e estereofônicos, então, para a transmissão de uma quantidade maior de canais, a alternativa encontrada foi realizar a codificação de cada canal separadamente com o modo monofônico e concatená-los em um mesmo pacote de rede, de forma semelhante à realizada no envio de pacotes contendo o formato PCM.

Para evitar que as chamadas de funções de codificação e decodificação bloqueassem o callback do JACK e com isso potencialmente causassem falhas na reprodução e/ou captura do áudio, a estrutura dos buffers utilizados no aplicativo foram modificadas. Primeiramente, em contraste com o método original em que um único buffer agregava todos os canais de áudio a serem processados, cada canal passou a possuir o seu próprio buffer, fazendo com que a função sendo executada dentro do callback simplesmente copie as amostras de dentro da aplicação para o JACK e vice-versa, como ilustrado na listagem 6.

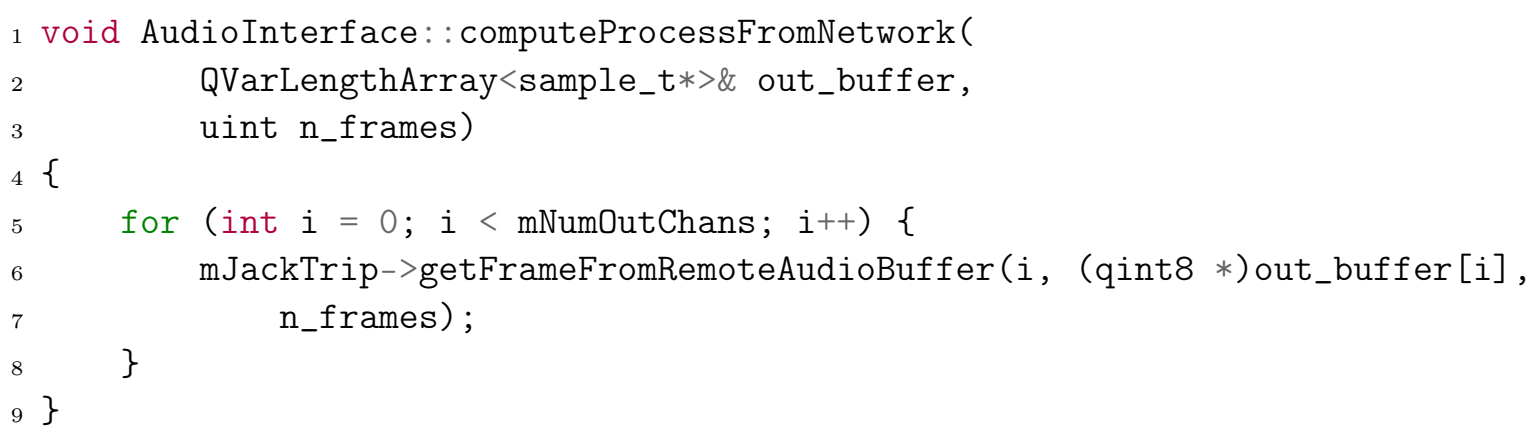

Listagem 6: Cópia dos blocos de áudio da rede para o JACK

Devido ao uso de threads para a codificação e decodificação do áudio, houve a necessidade da utilização de dois tipos de buffers: um lidando com os pacotes da rede (NetworkBuffer) e outro com os blocos de áudio (AudioBuffer), ambos subclasses do RingBuffer original. Embora tecnicamente fosse possível utilizar a própria thread de comunicação pela rede para o processo de codificação do áudio, por questões de organização e estruturação do código do programa, foi optado pelo uso de threads dedicadas para tal operação. A estrutura do JackTripMod resultante pode ser observada na fig. 3.9.

O funcionamento dos novos buffers é similar ao original do JackTrip, em que, no envio pela rede, todos os buffers envolvidos têm seus dados consumidos o mais rápido possível. No sentido inverso, o buffer de rede é consumido imediatamente, porém o buffer de áudio retém os dados para compensar o jitter da rede e disponibilizá-los na frequência correta para o JACK. A implementação nova corrige o comportamento original, permitindo ao usuário escolher um limiar mínimo de preenchimento do buffer para o repasse de dados de áudio para o callback do JACK. Apesar disso, o método original continua sendo acessível, caso o usuário deseje utilizá-lo. 


\section{Largura de Banda}

Ao permitir ao usuário escolher a taxa de bits que será utilizada com o codificador CELT, a largura de banda necessária para uma performance musical distribuída pode ser diminuída consideravelmente, de acordo com o que for adequado para a conexão em que o participante se encontra. Para estimar o uso de banda médio, temos que considerar, além da taxa escolhida, qual será o tamanho dos cabeçalhos no pacote de rede e a frequência com que os mesmos são enviados. Com isso, podemos calcular o uso de largura de banda de forma bastante semelhante à realizada na seção 3.1 .3 (página 40).

Considerando a sugestão dos próprios criadores do formato, de se usar taxas de 64 kbps por canal para música, a largura de banda necessária para uma performance musical distribuída usando o CELT gasta cerca de 138 kbps. Comparados aos mais de 1400 kbps necessários para uma transmissão no JackTrip original com PCM, o ganho é expressivo, apesar de existir uma perda de qualidade dado que é realizada uma compactação com perdas.

\subsubsection{Divisão de Pacotes}

Uma nova possibilidade, dada a nova configuração dos buffers descrita na seção anterior, é permitir o desacoplamento entre o tamanho do bloco de áudio do JACK e a quantidade de amostras que serão utilizadas no codificador/decodificador e, por consequência, a quantidade enviada em cada pacote de rede.

É importante ter esta funcionalidade por duas razões: a primeira é para efetivamente poder usar codificadores que possuem limitações em relação à quantidade de amostras por bloco processado, como o próprio CELT, que só aceita blocos de 64 a 512 amostras. Caso um computador esteja sofrendo com falhas na reprodução de áudio ao se utilizar um JACK configurado para 512 amostras por bloco, a solução mais simples seria aumentar este parâmetro para 1024 amostras, porém, isso acabaria impedindo o uso do CELT e forçaria o usuário a utilizar codificação PCM, necessitando de uma largura de banda que poderia não estar disponível. Ao desacoplarmos o tamanho do bloco do JACK daquele utilizado pelo codificador, esse problema não ocorre mais, já que, caso o JACK seja configurado com um tamanho de bloco pequeno demais para o codificador, o próprio JackTripMod pode armazenar as amostras em um buffer e repassar para a thread de codificação de forma transparente, ocorrendo processo semelhante caso a configuração do JACK use um tamanho de bloco grande demais. Obviamente, com isso, a latência passa a depender diretamente desta configuração da própria aplicação e não do tamanho de bloco utilizado no JACK como ocorre no JackTrip.

A outra vantagem deste método é permitir a divisão de pacotes de rede através da própria aplicação. Embora o protocolo IP realize um processo de fragmentação de pacotes assim que eles se tornem grandes demais para transmissão pelos dispositivos da rede, ainda existem vantagens em se tratar este problema dentro do próprio programa. Algumas limitações existentes em sistemas operacionais Mac OS X não permitem que sejam enviados pacotes UDP maiores que 9216 bytes por padrão, ao invés do máximo de 65536 bytes possíveis no protocolo IP ${ }^{13}$. Por exemplo, se um usuário do JackTrip original desejasse realizar uma performance musical distribuída com mais de 8 canais codificados em PCM 16 bits e blocos de áudio de 512 amostras utilizando máquinas Macintosh, ele encontraria um erro na aplicação, enquanto em sistemas Linux e Windows ele observaria ser possível utilizar até 63 canais. Ao permitirmos a divisão dos pacotes no próprio JackTripMod, apesar da limitação do sistema ainda existir, o usuário pode contornar o problema com maior facilidade, já que o usuário poderia continuar utilizando blocos de 512 amostras no JACK, mas passar a enviar 256 amostras por pacote de rede, chegando a 17 canais de áudio simultâneos.

A quantidade máxima de canais possível nesse caso pode ser calculada através da seguinte fórmula (medida em bits ou bytes):

$$
\text { canais }=\left\lfloor\frac{\text { tamanho máximo do pacote UDP }- \text { tamanho do cabeçalho }}{\text { resolução da amostra } \times \text { amostras em um bloco }}\right\rfloor
$$

\footnotetext{
${ }^{13}$ É permitido ao usuário ajustar manualmente o tamanho de pacotes executando o comando sysctl net. inet. udp. maxdgram=<tamanho desejado em bytes $>$ em um terminal, a fim de permitir o envio de pacotes maiores.
} 
Através deste método também se torna possível enviar uma quantidade muito maior de canais, independentemente da limitação do protocolo UDP. No limite, poderíamos montar pacotes que enviam apenas uma amostra de cada canal, fazendo com que o limite de canais no JackTripMod quando configurado com PCM 16 bits e JACK com 512 amostras por bloco passe de 63 canais para mais de 30 mil canais de áudio. Embora a utilidade prática deste número de canais possa ser discutível e exista um grande aumento na largura de banda utilizada, causado pela frequência de envio de pacotes e pelo tamanho do overhead por causa dos cabeçalhos utilizados, é preferível haver um limite alto demais a impedir a concretização de uma ideia musical, devido a uma tecnicalidade da implementação dos sistemas envolvidos, do que a situação atual de um limite muito baixo em relação ao uso já estabelecido em performances musicais distribuídas.

\subsubsection{Configurações Distintas}

Uma limitação do JackTrip era permitir somente performances musicais distribuídas em que ambos os participantes utilizassem exatamente as mesmas configurações, caso contrário o processo era finalizado. Ao receber o primeiro pacote de áudio, o cabeçalho era lido e, as informações contidas no mesmo eram utilizadas para decidir se a performance musical distribuída seria ou não realizada. Esse comportamento ocorria pois a inicialização dos buffers locais e remotos era feita logo na abertura do processo a partir dos parâmetros de configuração escolhidos localmente.

Dado que as informações necessárias já eram transmitidas pela versão original do software, a modificação realizada precisou alterar o ponto de inicialização de alguns elementos do programa, fazendo com que os buffers locais sejam instanciados conforme os parâmetros passados para o software, da mesma forma que já ocorria anteriormente, enquanto que o buffer de rede remoto e o decodificador são criados a partir dos parâmetros enviados pelo usuário remoto.

Como as conexões de Internet brasileiras em grande parte possuem taxas de download e upload assimétricas, é importante possuir uma certa flexibilidade em relação às configurações utilizadas nos participantes das performances musicais distribuídas, ainda mais com a diferença de largura de banda exigida pelos codificadores PCM e CELT. Caso apenas um dos usuários tenha a possibilidade de enviar áudio em PCM por possuir uma alta taxa de upload, é interessante permitir que a outra parte receba este sinal de maior qualidade, ainda que esta outra parte precise transmitir o seu próprio áudio codificado com CELT para economizar banda; este cenário ilustra a utilidade de configurações distintas, o que vai permitir a maior qualidade possível para cada usuário, dadas as respectivas restrições de largura de banda.

É importante ressaltar que, apesar das modificações realizadas causarem grandes alterações na flexibilidade do software, algumas limitações ainda têm de ser impostas em relação a algumas configurações. Por exemplo, a versão atual não permite que usuários realizem uma performance musical distribuída com taxas de amostragem diferentes, já que isso implica nas mesmas dificuldades observadas em relação à utilização da codificação OPUS, como discutido na página 45.

Outra limitação diz respeito à quantidade de canais utilizada, dependendo da API escolhida. No JACK, é possível instanciar quantos canais forem desejados, já que se tratam de canais de áudio que independem da quantidade fisicamente disponível na placa de som, sendo que os mesmos podem ser roteados da forma que o usuário desejar, podendo ele tanto utilizar o canal de áudio isoladamente, alimentando a entrada de algum programa de processamento sonoro, quanto mixá-lo com outros canais e direcioná-lo para a interface física, permitindo uma grande flexibilidade no gerenciamento das conexões multi-canal.

No RtAudio, porém, o número físico de entradas e saídas impõem limitações e dificuldades quanto ao mapeamento dos canais. Embora seja possível desenvolver uma solução que possibilite ao usuário escolher como os canais serão reproduzidos pelo dispositivo de áudio, isso seria uma reimplementação daquilo que o JACK já oferece. Por isso, se optarem por usar RtAudio, é obrigatório que ambas as partes utilizem o mesmo número de canais. Em muitas ocasiões esta limitação não acarreta em problemas, pois o uso de som estéreo, tanto na entrada quanto na saída de áudio, é bastante comum. 


\subsubsection{Modelo de Retorno Atrasado}

Em casos em que não é possível uma interação musical com latências inferiores aos 25 ms do limiar de performance em conjunto, uma forma alternativa de se permitir a realização de performances musicais distribuídas é através do uso de modelos diferenciados de performance, como discutido na seção 2.1. De todos eles, apenas dois precisam de implementações no software para serem viáveis: o modelo de tempo falso, coberto pelo NINJAM, e o modelo de retorno atrasado.

Embora o modelo de retorno atrasado esteja disponível no SoundJack, sua funcionalidade não é a ideal. Nele, o próprio usuário precisa definir qual será o atraso local adicionado pelo software, que pode ser muito diferente da latência real observada na transmissão de rede, fazendo com que o participante possa ter uma resposta muito atrasada, trazendo apenas desconforto ao músico, ou então bastante antecipada, o que o afastaria do modelo de retorno atrasado e diminuiria a sensação de sincronia entre as partes.

Por isso, na implementação realizada no JackTripMod, o atraso local aplicado pelo software depende diretamente das latências observadas no trajeto do áudio através de rede. Para que isso se tornasse possível, foi preciso criar um buffer de áudio que armazena o próprio sinal de entrada e o atrasa de acordo com um parâmetro variável, controlado automaticamente pelo software. Para definir este parâmetro de atraso, é necessário monitorar periodicamente tanto a latência introduzida pela rede quanto aquela causada pelo uso de buffers.

Para podermos estimar a latência da rede, foi implementado um procedimento análogo ao feito pela ferramenta ping. A grande diferença se dá no protocolo utilizado: ao invés do ICMP (Internet Control Message Protocol ou Protocolo de Mensagens de Controle da Internet), o JackTripMod realiza a medição de latência através de UDP, o mesmo protocolo usado pelos pacotes de áudio.

O método do ping é bastante simples: é enviada uma mensagem para um destino e, ao chegar, uma resposta é mandada para o remetente. Durante este procedimento, o ponto inicial cronometra o tempo que levou para a mensagem ir e voltar, determinando a latência total do trajeto. A partir deste valor, pode-se supor que metade do tempo foi gasto na ida e a outra metade na volta, obtendo assim um valor estimado para a latência da rede. Normalmente este processo é repetido diversas vezes e é tomada uma média para diminuir a influência do jitter.

No JackTripMod, o uso de UDP ao invés de ICMP foi feito para que os pacotes sejam enviados através dos mesmos mecanismos de software, e para evitar que roteadores que estejam configurados para não responderem às mensagens de ping, por motivos de segurança, impeçam nossa aplicação de estimar a latência da rede.

Outro aspecto a ser considerado quando desejamos atrasar o áudio local de acordo com a influência dos meios de transmissão na latência é o tamanho do buffer utilizado. Como o tamanho do buffer é configurável, o usuário poderia ajustá-lo para um valor demasiadamente grande, como por exemplo, 1 segundo. Neste cenário, ainda que a latência da rede estivesse na casa das dezenas de milissegundos, fica fácil perceber que a latência total do sistema seria influenciada por estes dois aspectos, e o áudio local seria atrasado de acordo com a soma destes dois fatores.

\subsubsection{Tratamento de Buffer}

Os buffers de áudio utilizados no código original ofereciam diversas oportunidades para a implementação de novas funcionalidades. Nesta seção discutiremos algumas de suas novas características.

\section{Dimensionamento}

Para auxiliar o usuário no processo de dimensionamento adequado do buffer de recebimento de áudio pela rede, é utilizada uma técnica que estima o tamanho necessário para evitar que as flutuações causadas no recebimento de pacotes (jitter) acabem resultando em falhas na reprodução do áudio.

A ideia por trás do método utilizado é estimar o jitter não pelo processo de ping, como normalmente é feito, mas sim através da própria taxa de recebimento dos pacotes de áudio pela rede. Como sabemos que o envio é realizado de forma periódica, conforme o callback realizado pelo JACK é chamado, 
o intervalo de tempo no recebimento de pacotes da rede deveria ser constante se não houvessem variações de latência no meio de transmissão utilizado. Como normalmente o jitter observado não é nulo, podemos estimar a variação futura através de medidas do passado.

Assim, conforme os pacotes de áudio são recebidos pela rede, a aplicação vai armazenando o intervalo de tempo entre os pacotes e gerando estatísticas sobre estes intervalos. Como a média destes intervalos corresponde ao próprio intervalo entre as chamadas realizadas ao callback, esta informação não nos auxilia a estimar um tamanho de buffer adequado. No entanto, se calcularmos o desvio padrão destes intervalos, obtemos uma medida adequada e realista para o jitter. A partir deste valor, podemos alterar os parâmetros do buffer de recebimento para que este reflita o estado atual da rede.

\section{Esvaziamento e Enchimento}

Por melhor que seja sua estimativa de tamanho de buffer, é impossível prever o comportamento real da rede, já que ela depende do estado de diversas outras conexões não diretamente relacionadas àquela em que estão sendo realizadas as performances musicais distribuídas. Por isso, por maior que seja o buffer ainda assim podemos ser vítimas de um congestionamento de pacotes que impeça o seu recebimento em uma taxa adequada para a reprodução. Quando o fluxo de dados é insuficiente para manter o buffer cheio a aplicação precisa tomar uma decisão quanto ao que será reproduzido pela API de áudio enquanto novos pacotes não são adquiridos.

No JackTrip, dois métodos são disponibilizados para tais ocasiões: o software pode passar a enviar um bloco de áudio vazio, nos quais o usuário observará um trecho sonoro silencioso, ou então é realizada a repetição do último bloco recebido, até que a situação se normalize.

De forma semelhante, também é possível que um acúmulo de pacotes na rede ocasione um enchimento completo do buffer. Neste caso, o JackTrip simplesmente descarta metade do conteúdo já armazenado para permitir que novos pacotes sejam acomodados.

Um método alternativo pode ser escolhido no JackTripMod, em que a forma com a qual o buffer é tratado passa a ser ligeiramente diferente em relação ao original. Dois novos limiares são estabelecidos além daquele que define o início da reprodução de áudio: um limite inferior para quando o buffer estiver próximo de se tornar vazio e um superior para prevenir que o oposto ocorra. Estes novos limiares são necessários pois a técnica proposta baseia-se em "esticar" o sinal de onda para suprir pequenas interrupções. É preciso algum conteúdo no buffer ao se atingir o limiar inferior, caso contrário não teremos nenhuma informação para ser processada e ocupar o vazio necessário. No caso do limiar superior, a ideia consiste em não descartar nenhum trecho de áudio, mas sim "espremer" o mesmo para que haja espaço suficientemente disponível.

Um aspecto incômodo da técnica utilizada é a alteração do pitch do trecho de áudio quando os redimensionamentos são realizados, tornando o som mais grave quando for necessário aumentar seu tamanho e mais agudo quando for preciso diminuir. No entanto, é bom observar que a funcionalidade original do JackTrip também não providencia uma solução perfeita, já que apenas preenche o sinal com silêncio, não havendo pitch nenhum envolvido, ou, ao reproduzir o último bloco recebido repetidamente, cria um sinal de altura proporcional ao tamanho do bloco sendo reproduzido, ou ainda apenas cria uma descontinuidade no sinal quando seu buffer está cheio.

Algumas formas distintas de se atingir tal objetivo foram implementadas, todas como sendo subclasses de FrameResizer, sendo que esta representa a funcionalidade original do JackTrip. Três métodos diferentes possíveis para realizar este redimensionamento do sinal de áudio foram implementados: arredondamento, interpolação linear e cúbica [Puc07].

Arredondamento A alternativa mais simples para alterar o comprimento de uma onda amostrada é simplesmente ler repetidas vezes alguns pontos caso se deseje alongá-la e pular pontos se o interessante é encurtá-la. O algoritmo de arredondamento realiza este procedimento, alterando assim o tamanho final do sinal.

Dado um sinal com $n$ amostras, desejamos transformá-lo em um outro de tamanho $m$. Para isso faremos com que cada amostra $r_{i}, i \in\{1, \ldots, m\}$ no bloco redimensionado seja calculada a partir das 


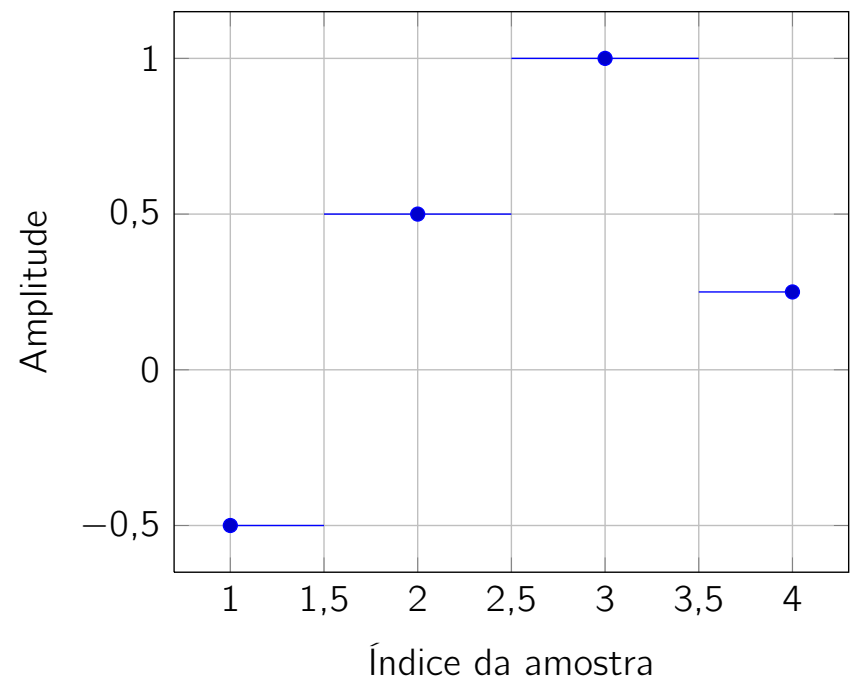

Figura 3.10: Arredondamento

amostras $a_{j}, j \in\{1, \ldots, n\}$ onde

$$
j=\operatorname{round}\left(\frac{i \times n}{m}\right),
$$

sendo round $(x)$ a função que calcula o inteiro mais próximo de $x$. Os valores das amostras podem ser observados na fig. 3.10. Todo índice fracionário simplesmente irá obter o valor da amostra mais próxima. Caso seja escolhido um índice como o 1,5 da figura, o resultado dependerá da função de arredondamento utilizada.

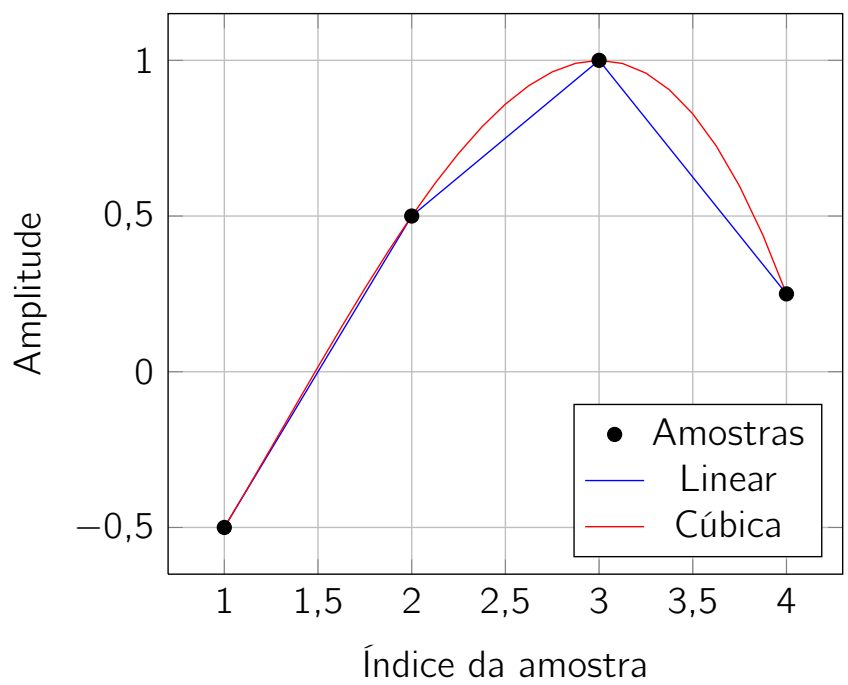

Figura 3.11: Interpolação linear e cúbica

Interpolação linear $O$ segundo método implementado infere os valores entre duas amostras através do valor encontrado com um segmento de reta que as conecta, permitindo obter resultados através de índices de amostra fracionários. Embora os valores utilizados no exemplo da fig. 3.11 sejam os mesmos, podemos observar que o bloco redimensionado obterá resultados bastante diferentes dos do método de arredondamento.

Para obter os valores desejados, calculamos os índices fracionários de forma similar ao método anterior, apenas não arrendondamos o resultado: 


$$
j=\frac{i \times n}{m}
$$

Assim, os valores desejados serão dados por

$$
r_{i}=(1-\delta) \times a_{\lfloor j\rfloor}+\delta \times a_{\lfloor j+1\rfloor}, \operatorname{com} \delta=j-\lfloor j\rfloor
$$

Interpolação cúbica $O$ último procedimento implementado utiliza a informação de um número maior de amostras vizinhas, necessitando de quatro pontos para realizar a interpolação. Para seu cálculo, usamos a seguinte fórmula, com $\delta$ e $j$ definidos da mesma forma que na interpolação linear.:

$$
\begin{aligned}
r_{i}= & -\delta(\delta-1)(\delta-2) / 6 \times a_{\lfloor j-1\rfloor} \\
& +(\delta+1)(\delta-1)(\delta-2) / 2 \times a_{\lfloor j\rfloor} \\
& -(\delta+1) \delta(\delta-2) / 2 \times a_{\lfloor j+1\rfloor} \\
& +(\delta+1) \delta(\delta-1) / 6 \times a_{\lfloor j+2\rfloor}
\end{aligned}
$$

Na fig. 3.11 podemos observar a diferença entre a interpolação linear e cúbica. É importante ressaltar que, apesar de utilizarmos quatro amostras neste método e a figura indicar o resultado da equação acima no intervalo $[1,4]$, o trecho interpolado que será utilizado é somente o intervalo [2,3] formado pelos dois pontos centrais. Quando desejarmos o valor do segmento seguinte, recalculamos a fórmula utilizando novos pontos, abandonando a primeira amostra e utilizando uma nova amostra à direita.

\subsubsection{Múltiplas Conexões}

No JackTrip original, um processo pode se conectar somente a um único computador remoto. A única forma de realizar performances musicais distribuídas com mais de um usuário é abrindo diversas vezes o programa e manualmente alterando as opções de conexão para evitar que a aplicação tente usar uma porta já alocada a algum outro participante. Embora isso seja viável tecnicamente, outro problema é criado: se os músicos estão cada um em locais diferentes, a distância entre cada par de participantes em geral é diferente e, por consequência, serão diferentes as latências obtidas nas conexões de rede. Como estas latências são independentes do ponto de vista do JackTrip, nenhum tipo de sincronia é possível.

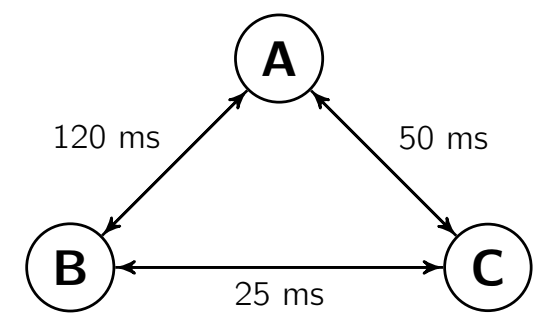

Figura 3.12: Cenário com múltiplos participantes

Considere, por exemplo, três músicos $A, B$ e $C$ que participam de uma performance musical distribuída com as latências ilustradas na fig. 3.12 (supondo que o tempo de ida e volta dos pacotes de rede são iguais). Embora possa parecer estranho o trecho $A B$ ter uma latência maior do que se combinados os trechos $B C$ e $C A$, isso é inteiramente possível dado que o usuário de Internet não tem o poder de escolher a rota que os pacotes irão tomar. Não é difícil observar este tipo de ocorrência em jogos eletrônicos online, nos quais, dentre os diversos jogadores conectados simultaneamente a um mesmo servidor, alguns possuem uma latência muito maior devido às rotas tomadas pelos pacotes, mesmo que todos estejam a distâncias aproximadamente iguais do servidor. 
A maior dificuldade de um cenário desse tipo é a grande variação nos ambientes musicais observados por cada um dos participantes, caso nenhuma forma de sincronização seja realizada. Por exemplo, enquanto que com apenas dois músicos $(A$ e $B$ ) seja possível realizar uma performance sem sincronia, em que $A$ seja o mestre e $B$ seja o escravo, e onde $B$ ainda poderia ter a percepção de uma interação natural em detrimento da posição observada por $A$, como detalhado na seção 2.1 , neste modelo expandido isso já não se torna mais viável, dado que do ponto de vista do terceiro elemento $C$, todos os sinais de áudio estão fora de sincronia e qualquer interação dele com os outros músicos também não estará sincronizada, não resultando em uma performance natural sob nenhum ponto de vista.

O primeiro passo para a construção de uma solução que permitisse o envolvimento de diversos participantes em uma mesma performance musical distribuída foi a criação de um sistema que pudesse gerenciar diversas instâncias da classe JackTrip do projeto original, já que estas agregavam as principais funcionalidades da aplicação.

Para que o áudio entre as diversas partes fosse sincronizado dentro do modelo de retorno atrasado, tanto as latências entre as diversas partes quanto os tamanhos de buffer de áudio sendo utilizados precisaram ser considerados. Dado que para a implementação do modelo de retorno atrasado já havia sido desenvolvido um módulo com esta finalidade, o mesmo foi reutilizado juntamente com um método que simplesmente devolve o quão cheio o buffer de áudio atual está. Com isso, apenas foi necessário adicionar um pequeno controlador que mantém atualizado o estado estimado da rede e, calculando o maior atraso dentre todos os participantes conectados a ele, altera os tamanhos dos buffers de áudio de forma a todos terem este mesmo valor.

Uma observação importante neste caso com múltiplos músicos conectados entre si é que o modelo de retorno atrasado passa a ser uma abordagem de grande valia para a viabilização da performance musical distribuída. Com a técnica implementada no JackTripMod podemos analisar uma situação como a da fig. 3.12, em que teremos que a latência percebida por cada nó será dada pelo máximo entre as latências das conexões que chegam a ele. Por exemplo, para $A$, o áudio vindo tanto de $B$ quanto de $C$ terá um atraso de $120 \mathrm{~ms}$, mesmo valor observado em $B$. Porém, para $C$, o buffer de áudio será ajustado para causar um atraso de $50 \mathrm{~ms}$. Embora estes valores sejam distintos, podemos observar que o sinal recebido estará sincronizado em todos os nós. Supondo que no instante $t$ todos os participantes emitiram um som $s$, teremos que tanto para $A$ quanto para $B, s$ será reproduzido em $t+120$, devido aos atrasos artificiais introduzidos onde a latência é menor que 120 (incluindo o áudio local), enquanto que para $C, s$ simplesmente será reproduzido em um instante anterior, $t+50$, porém ainda sincronizado. Isso significa que alguns trechos da rede com latência maior não condenam necessariamente todos os participantes da performance musical distribuída a tocar com um atraso local aumentado.

Uma possível alteração futura no JackTripMod seria, a partir do conhecimento das latências observadas entre os diversos nós, permitir o gerenciamento de servidores de retransmissão; no exemplo anterior, o nó $C$ poderia servir de retransmissor na comunicação entre $A$ e $B$, o que traria uma melhora na latência observada no sistema. Para que esta implementação fosse possível, grandes mudanças estruturais no projeto teriam de acontecer, já que parte da comunicação teria como finalidade encontrar a estrutura ideal para a performance musical distribuída automaticamente. Para isso, seria interessante termos, além do canal de transmissão de áudio, um canal de controle implementado com o protocolo TCP para evitar que as possíveis perdas de mensagem do UDP criassem problemas para a configuração do sistema. Além disso, cada nó passaria a ser responsável pela retransmissão do áudio recebido se necessário, existindo duas possibilidades: simplesmente repassar os pacotes, o que elevaria a largura de banda de upload necessária, ou mixar automaticamente o sinal recebido com o áudio a ser enviado, o que causaria uma depreciação na qualidade sonora caso fosse utilizado um codificador com perdas, pois o pacote recebido teria de ser descompactado, mixado e novamente compactado.

Outra abordagem possível seria alterar a topologia utilizada no JackTripMod, passando do modelo P2P para o servidor-cliente, permitindo ao mesmo tempo que qualquer um dos músicos na performance musical distribuída faça o papel do servidor e possa participar da performance juntamente com os outros clientes. Esta solução teria duas vantagens: o fato de se ter um uso de largura de banda menor no sistema como um todo e a simplificação do processo de sincronização entre todos os participantes. 
Podemos notar que, se cada nó está enviando $b \mathrm{kbps}$, em um modelo P2P com $n$ participantes, teremos que cada um gastará $(n-1) \times b$ kbps, fazendo com que o total de largura de banda utilizada para envio de dados será de $n \times(n-1) \times b$ kbps. Em contrapartida, em uma estrutura cliente-servidor, dos $n$ participantes, os $(n-1)$ clientes enviarão $b$ kbps e o servidor necessitará de $(n-1) \times b$, totalizando $2 \times(n-1) \times b \mathrm{kbps}$, reduzindo a largura de banda utilizada pelo sistema em um fator de $n / 2$ se comparado ao modelo P2P.

Em relação à sincronização, temos que o servidor passaria a funcionar como uma espécie de "regente", garantindo que todos os nós passassem a ouvir exatamente o mesmo áudio, já que cada cliente enviaria seu sinal para o servidor, que mixaria todos os sinais com as devidas correções de atraso, e mandaria a versão mixada de volta para cada cliente.

As desvantagens de se adotar um servidor central de mixagem são decorrentes da necessidade de se descompactar o áudio de cada nó e compactar novamente após a mixagem, o que leva a uma degradação na qualidade do sinal no caso de compactadores com perdas, além de uma maior necessidade de capacidade de processamento do servidor. Por exemplo, se for desejado que cada usuário tenha um controle individual das amplitudes de cada faixa recebida, isto terá de ser realizado pelo próprio servidor já que o sinal que cada cliente recebe já estará mixado, e qualquer mudança que um cliente realizasse em seu mix levaria algum tempo para surtir efeito devido às latências envolvidas no processo de comunicação com o servidor. Uma solução seria fazer do servidor apenas um elemento que retransmite todos os pacotes que chegam a ele, porém neste caso a economia de largura de banda obtida desapareceria, já que o servidor precisaria enviar $(n-1) \times(n-1) \times b \mathrm{kbps}$, o que, somado à banda de upload utilizada pelos clientes, resultaria em um total de $n \times(n-1) \times b$, exatamente 0 mesmo necessário para conexões P2P, com o agravante de apresentar um nó bastante sobrecarregado (o próprio servidor) em comparação com os outros.

A solução proposta no JackTripMod é um meio termo entre as diversas variáveis apresentadas, expandindo o modelo já utilizado no programa original para seu uso em performances com múltiplos participantes. Como discutido, embora seja possível otimizar certos aspectos da performance modificando o modelo utilizado, as melhorias se baseiam em um balanceamento entre questões técnicas da infraestrutura utilizada e a percepção musical envolvida em uma performance musical distribuída.

\subsubsection{Usabilidade}

O JackTrip é completamente operado através da linha de comando e, embora o seu uso seja importante, não se pode negar a predominância de aplicações com interfaces gráficas nos sistemas operacionais modernos. Para evitar que o usuário tenha a necessidade de utilizar terminais em sistemas operacionais que não expõem essa funcionalidade ao usuário, como o Windows, funcionalidades foram desenvolvidas para diminuir o nível técnico exigido do usuário para o uso do programa.

\section{Interface Gráfica}

Aproveitando-se do fato do JackTrip ser desenvolvido utilizando o arcabouço Qt, foi desenvolvida uma interface gráfica para estabelecer uma experiência mais amigável para o usuário final. A interface desenvolvida pode ser encontrada na fig. 3.13.

Alguns dos elementos utilizados na criação da interface gráfica se baseiam em características encontradas nos consoles de mixagem. Para cada usuário na performance musical distribuída podemos observar a existência de um controle de volume, um medidor de volume e botões para silenciar ou tornar a faixa associada a uma conexão a única a ser ouvida.

Para a realização de performances musicais distribuídas, o usuário deve apenas digitar o endereço a ser conectado, ajustar quaisquer configurações desejadas em uma janela própria para tal, e iniciar a transmissão de áudio. Apesar de ser um avanço do ponto de vista da usabilidade, ainda podemos diminuir a quantidade de conhecimento técnico necessário para que uma performance musical distribuída seja realizada eliminando a necessidade da troca de endereços IP através de algum outro meio de 


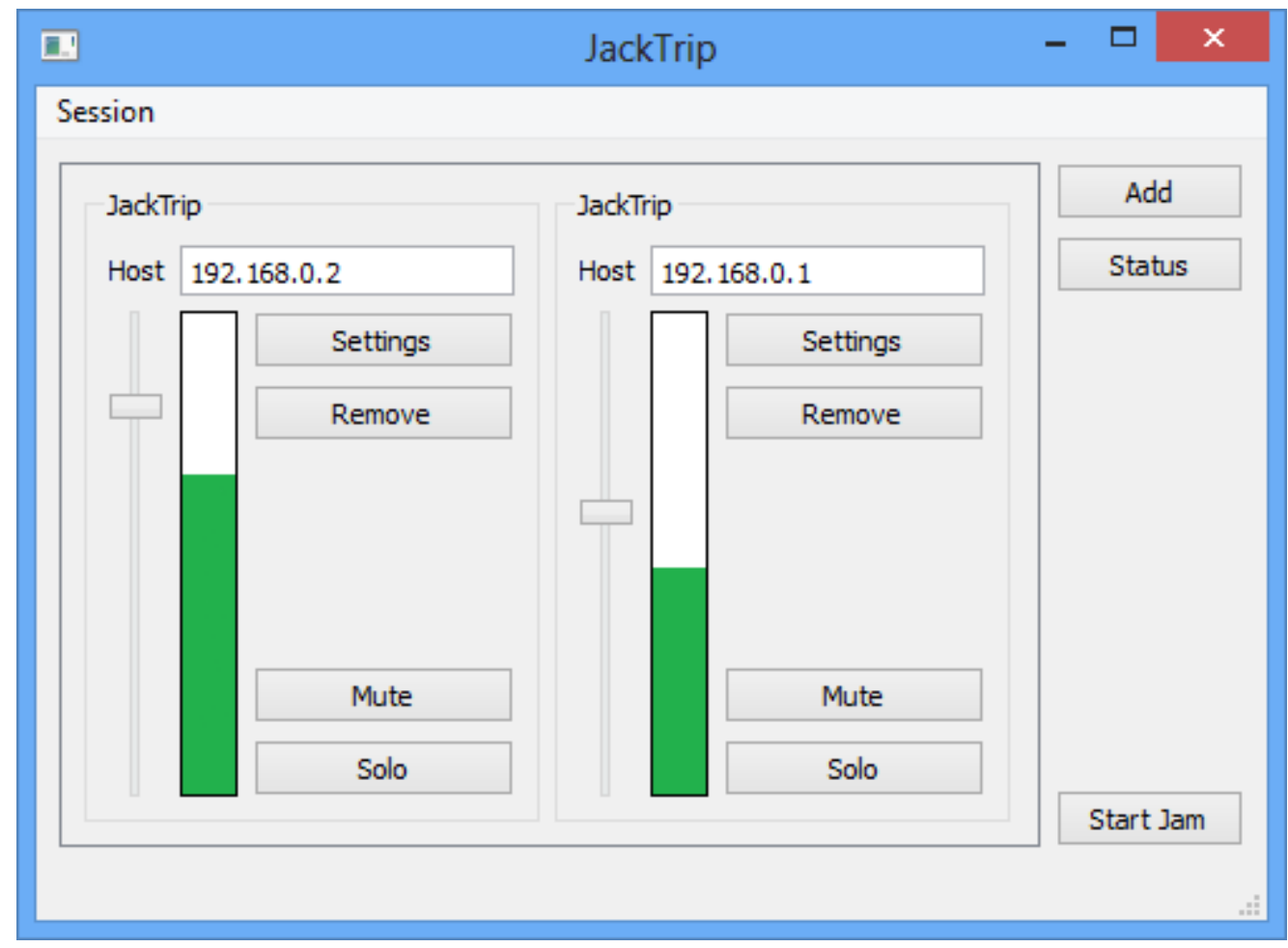

Figura 3.13: Interface gráfica do JackTripMod

comunicação. Para isso, foi utilizada a biblioteca libpurple, base da aplicação Pidgin ${ }^{14}$, uma ferramenta para a conexão em diversas redes de comunicadores instantâneos como o Google Talk, ICQ, Yahoo! Messenger, dentre outros.

\section{Plugin para libpurple}

A criação deste plugin tem como objetivo proporcionar aos usuários do JackTripMod uma experiência mais semelhante àquela oferecida pelo Skype. Através do protocolo XMPP (Extensible Messaging and Presence Protocol ou Protocolo de Mensagens e Presença Extensível) [SA11a, SA11b], também conhecido pelo seu antigo nome Jabber, é possível realizar a troca de mensagens customizadas, auxiliando na realização de conexões do JackTripMod.

Ao invés de hospedarmos um servidor para que todos os usuários da aplicação possam se reunir, como o Sound Jack faz, ou implementarmos um novo protocolo de comunicação, tal qual o Skype, simplesmente aproveitamos a infraestrutura já existente de serviços de comunicação instantânea que permitem a seus usuários, dentre diversas outras funcionalidades, gerenciar uma lista que indica se seus contatos estão online ou não. Como protocolos como o Google Talk são implementações do XMPP, é possível expandir as funcionalidades oferecidas e aproveitar a base de usuários já existente, evitando a criação de mais uma conta de acesso a um serviço por parte do usuário do JackTripMod ${ }^{15}$.

Outra vantagem de se utilizar a libpurple é que ela já possui funcionalidades para atravessar NATs, podendo efetuar mapeamentos através de UPnP ou NAT-PMP e também utilizar o STUN, diminuindo os problemas de conectividade.

Quando o usuário se conecta a uma rede XMPP, ele obtém a lista de todos os seus contatos que estejam disponíveis para conversa. O plugin desenvolvido adiciona a possibilidade de se enviar um convite para uma interação musical entre as partes. O procedimento é iniciado por uma das partes

\footnotetext{
${ }^{14}$ http://www.pidgin.im/ - Acessado em fevereiro de 2013

${ }^{15}$ Embora o SoundJack também não exija a criação de uma conta, a implementação deste não permite que cada participante possua uma lista privada de contatos, mas sim mantém uma sala pública em que é possível observar todos os usuários que estão executando a aplicação em seu modo de conexão automático, se assemelhando mais a uma sala de bate papo, como em um canal IRC.
} 
acionando a opção "Jam!" disponível no menu deste contato.

Para enviar um convite, o plugin tenta obter o IP público do usuário, mapear uma porta através do UPnP ou NAT-PMP e em seguida envia uma pequena mensagem XML chamada de IQ (Info/Query) stanza como a exemplificada na listagem 7.

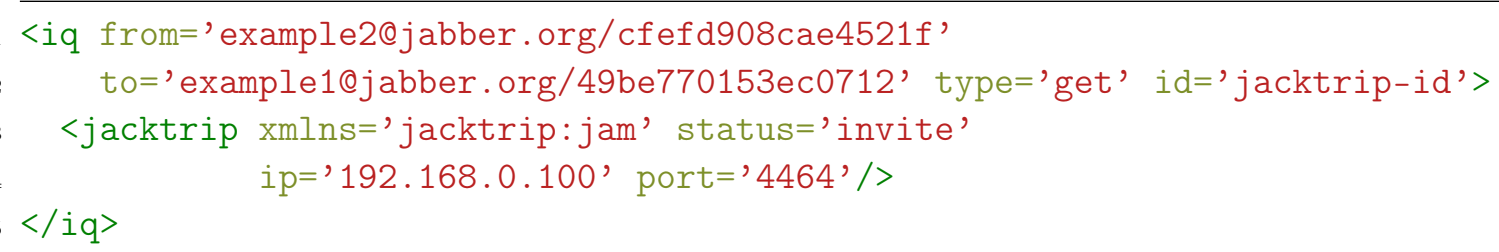

Listagem 7: Convite enviado pela libpurple

Neste exemplo, uma mensagem do tipo invite está sendo enviada para o destinatário do atributo to ${ }^{16}$, contendo o endereço ao qual o convidado deverá se conectar nos campos ip e port. O destino, a partir do nome do nó (jacktrip) e de seu espaço de nomes (namespace, em inglês), definido como jacktrip: jam, irá reconhecer ou não este tipo de mensagem. Caso o cliente XMPP usado não tenha o suporte necessário, uma mensagem de erro será enviada de volta ao remetente, como exemplificado na listagem 8.

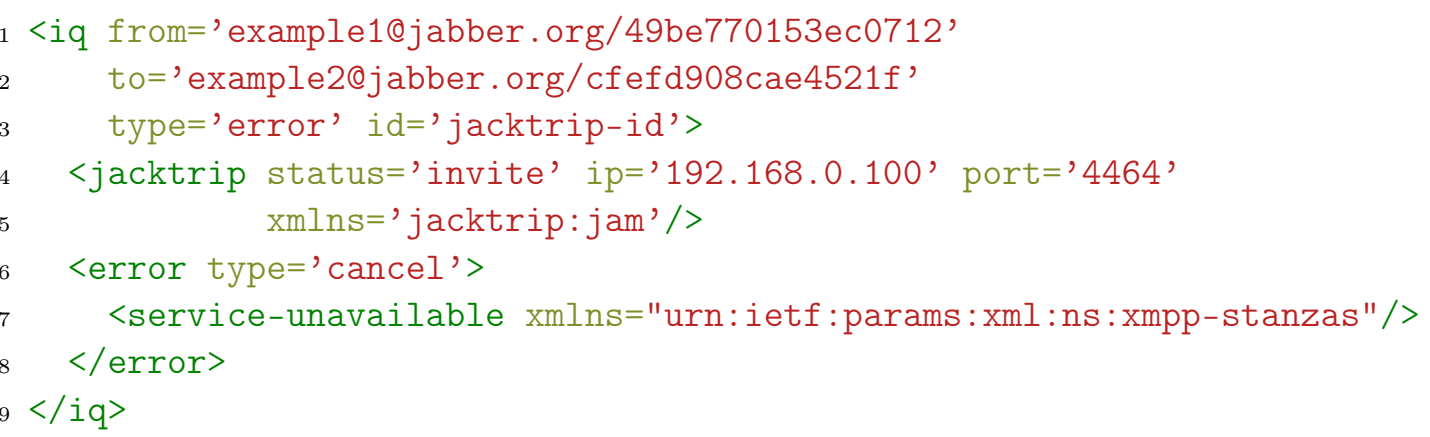

Listagem 8: Erro caso o cliente não possua o recurso disponível

Caso contrário, o destino tem a opção de aceitar ou recusar o convite. Em caso de recusa, a mensagem trocada é bastante simples e apenas contém o valor cancel no campo status (listagem 9), indicando a recusa.

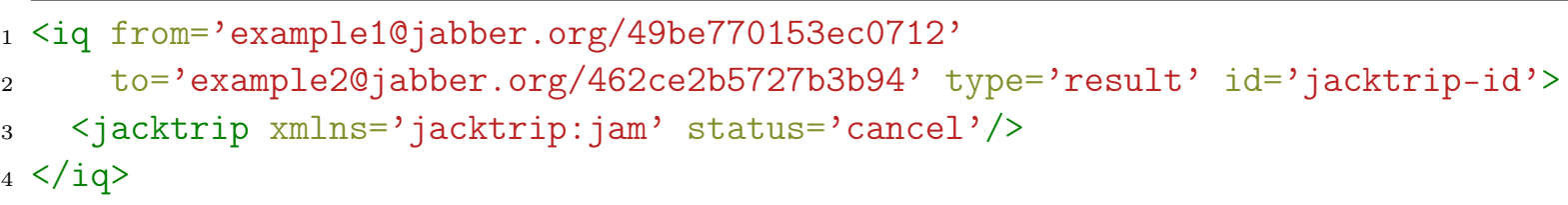

Listagem 9: Mensagem de cancelamento

Se o convite for aceito, o procedimento realizado é bastante semelhante ao do envio inicial: obtemos o endereço público do usuário com a ajuda do STUN, mapeamos através dos protocolos UPnP ou NAT-PMP e enviamos a resposta (listagem 10) indicando qual é o endereço ao qual o remetente deverá se conectar.

\footnotetext{
${ }^{16} \mathrm{O}$ formato utilizado tem a seguinte forma: $<$ nome do usuário $>$ Q $<$ domínio $>/<$ recurso $>$ e é chamado de Jabber $I D$ ou JID. Como um usuário pode estar conectado à rede através de diversos clientes, um recurso pode ser definido, porém este não é obrigatório.
} 


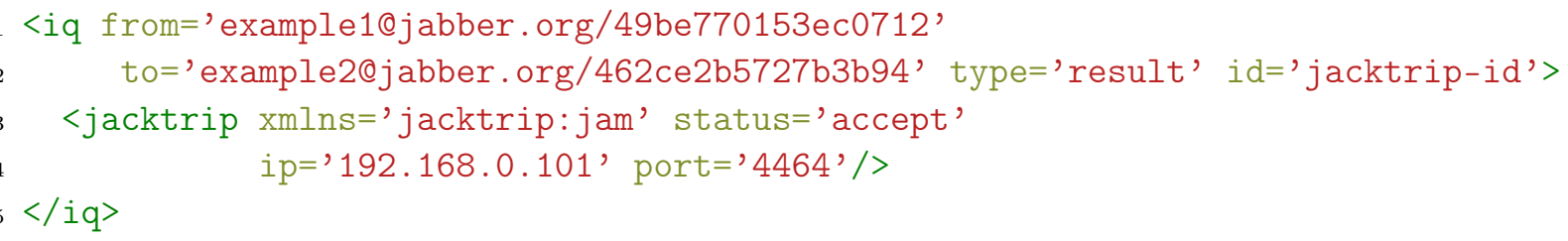

Listagem 10: Convite aceito

A partir deste momento, o plugin passa a se comunicar através da entrada padrão do sistema com uma instância do processo do JackTripMod que foi criada juntamente com a inicialização do plugin. Para que esta integração fosse possível, algumas modificações na aplicação foram necessárias: uma opção de linha de comando permite que o processo seja iniciado com sua interface gráfica escondida e diversos comandos podem ser dados para a aplicação através da entrada padrão, o que não era possível originalmente. Embora a principal motivação para a criação desta forma de controlar o programa tenha sido a comunicação entre o plugin e o processo do JackTripMod, nada impede que o usuário utilize esta interface para operar a aplicação.

Os seguintes comandos estão disponíveis:

- jacktrip-start: Inicia todas as conexões (equivalente a pressionar o botão "Start" na interface gráfica).

- jacktrip-stop: Interrompe a performance musical distribuída.

- jacktrip-add: Adiciona uma nova instância da classe JackTrip ao programa. Este comando aceita exatamente as mesmas opções que as utilizadas ao chamar o JackTripMod com opções na linha de comando.

- list-clients: Lista todas as instâncias da classe JackTrip existentes.

- show-window: Exibe a interface gráfica.

- hide-window: Esconde a interface gráfica.

- help: Lista todos os comandos disponíveis.

- quit: Sai do programa.

Assim, para a realização de uma performance musical distribuída, o usuário precisa apenas utilizar um serviço de mensagem instantânea baseado no protocolo XMPP para que o estabelecimento de uma conexão entre diversas partes seja consideravelmente mais simples do que o observado no JackTrip original, que exigia um mínimo de conhecimento técnico sobre redes para sua utilização. Embora o plugin desenvolvido funcione apenas com aplicações baseadas na libpurple, como o Pidgin, nada impede que funcionalidade semelhante seja implementada em outros clientes XMPP.

Juntamente com todas as outras modificações realizadas, o resultado obtido transformou o JackTrip em uma plataforma para performances musicais distribuídas com uma flexibilidade muito maior, removendo diversas limitações do programa original, e com uma maior acessibilidade também através das novas interfaces desenvolvidas. O conjunto de configurações padrão utilizado no JackTripMod visa abranger uma grande quantidade de cenários possíveis, onde o usuário nem sempre possui a conexão ideal, sofrendo com jitter, perda de pacotes e baixa largura de banda, porém nunca deixando de permitir a ele modificar as variáveis que influenciam sua performance.

Pode-se escolher utilizar um tamanho de buffer menor do que o sugerido para que a latência total obtida seja menor, mesmo que isso ocasione pequenas falhas na reprodução do áudio, ou então pode-se decidir participar de uma performance em que o áudio possua uma maior sincronia, utilizando modelo 
de retorno atrasado, por exemplo. Tudo isso através de uma interface mais amigável para os usuários e evitando ao máximo a possibilidade de que NATs atrapalhem a conectividade entre as partes, para que as performances musicais distribuídas possam ser bem sucedidas e de qualidade.

O projeto está hospedado na página http://sourceforge.net/projects/jacktripmod/. Nela, o usuário poderá encontrar tanto o código-fonte do programa quanto uma versão pré-compilada para Windows. Para sistemas Linux e Mac OS, a compilação deverá ser realizada manualmente. 


\section{Capítulo 4}

\section{Experimentos}

Neste capítulo, serão cobertos aspectos relacionados aos experimentos realizados com alguns dos softwares para performance musical distribuída. Primeiramente serão discutidos os métodos utilizados para a execução dos experimentos, seguidos de uma discussão de cada um dos resultados obtidos.

\subsection{Desenho Experimental}

Embora seja possível analisar os softwares e estabelecer algumas de suas características analiticamente (o uso de largura de banda, por exemplo), é importante realizar experimentos empíricos para que seja verificado se fatores externos aos programas para performances musicais distribuídas influenciam de alguma forma os resultados esperados.

Assim, alguns cenários foram preparados para que fosse possível comparar as características de alguns dos aplicativos específicos para performances musicais distribuídas entre si e também com softwares de VolP que, embora não dedicados para este fim, ainda assim são utilizados em certas ocasiões para a realização de performances.

Os softwares escolhidos foram o Sound Jack, o JackTrip, o JackTripMod e o Skype, sendo que os mesmos que já foram analisados anteriormente na capítulo 3. Com isso, os resultados nos permitem observar as diferenças que as modificações introduzidas no JackTrip causaram e também comparar suas características com o SoundJack, já que o mesmo não possui código aberto, tornando-se impossível realizar qualquer tipo de comparação baseando-se apenas em sua implementação. Além disso, a opção pelo Skype como exemplo de VolP se dá principalmente pela sua grande presença de mercado, e apesar do fato de seu código não ser aberto, o contexto experimental faz com que seja possível obter mais informações sobre o software ao observar os resultados obtidos. As versões utilizadas de cada software podem ser encontradas na tabela 4.1.

\begin{tabular}{ll}
\hline Software & Versão \\
\hline Skype & 4.0.0.8 \\
SoundJack & 9 de outubro de 2012 \\
JackTrip & revisão 501 (SVN) \\
JackTripMod & revisão d320d3f (Git) \\
\hline
\end{tabular}

Tabela 4.1: Versões testadas de cada software

As configurações dos computadores utilizados nos experimentos podem ser vistos na tabela 4.2.

Foram realizados experimentos para caracterizar a qualidade sonora, a largura de banda utilizada e a latência do sistema de cada um destes aplicativos. Nas seções seguintes, serão descritos mais detalhes das metodologias utilizadas em cada um destes experimentos juntamente com os resultados esperados e obtidos. 


\begin{tabular}{llll}
\hline Configuração & Computador 1 & Computador 2 & Computador 3 \\
\hline Sistema Operacional & Ubuntu 12.04 ×64 & Ubuntu 12.04 ×64 & Ubuntu 12.04 ×64 \\
Processador & Intel Core i5 750 & Intel Core 2 Duo T5550 & Intel Core i3 350M \\
Memória & 4 GB & 3 GB & 6 GB \\
Placa de Som & Realtek ALC889A & Realtek ALC262 & IDT 92HD81B1C \\
Placa de Rede & Realtek RTL8111D & Marvell 88E8039 & JMicron JMC250 \\
\hline
\end{tabular}

Tabela 4.2: Configurações dos computadores utilizados

\section{Largura de Banda}

A análise da largura de banda utilizada por cada um dos softwares é bastante simples e depende apenas de uma captura de pacotes feita com um analisador de pacotes de rede como o Wireshark ${ }^{1}$. Com ele, podemos capturar em um arquivo todos os pacotes enviados e recebidos através de uma interface de rede e salvamos eles em um arquivo que pode ser processado posteriormente. Então basta efetuarmos a conexão entre os computadores que participarão da performance musical e executarmos a captura com o Wireshark para que possamos calcular a largura de banda média utilizada durante a performance, já que com o arquivo salvo temos acesso aos tamanhos de cada pacote e o tempo de duração da captura.

Um cuidado que deve ser observado ao processarmos o arquivo de captura é que devemos filtrar os pacotes que serão contabilizados já que o analisador de pacotes captura todo o tráfego da rede. Assim, dados que estejam sendo enviados por outros softwares durante a captura podem influenciar os resultados se eles não forem excluídos corretamente da contagem. No caso do JackTrip, por exemplo, todo o áudio trafega pela porta 4464 de um soquete UDP, então todo o tráfego em outras portas pode ser descartado. O próprio Wireshark foi utilizado para a filtragem destes pacotes.

Dependendo das informações que o software disponibilizar, é possível estimar a largura de banda que será utilizada como já foi discutido nas respectivas seções de cada software testado (seções 3.1.3 e 3.3.1).

Para este teste, os computadores 1 e 2 foram conectados através de uma LAN, para que não fosse possível ter problemas de limitação na largura de banda disponível, e um sinal de áudio tocado pelo computador 3, contendo partes senoidais puras, ruído branco e música, foi transmitido com cada um dos aplicativos. Este sinal foi escolhido principalmente para evitar que alguma de suas características pudessem ser aproveitadas pelo codificador de algum dos softwares e, com isso, enviesasse o resultado. As configurações escolhidas para cada software foram as seguintes:

Skype Configuração padrão, pois não é permitido ao usuário alterá-la.

Sound Jack As quatro opções disponíveis foram testadas: o codificador OPUS com 48, 96 e 192 kbps, e o codificador PCM.

JackTrip Também foram testadas todas as configurações possíveis (PCM com 8, 16, 24 e 32 bits por amostra).

JackTripMod Quatro cenários semelhantes aos utilizados no teste do Sound Jack foram escolhidos para que fosse possível comparar os resultados com os outros softwares: PCM com 16 bits por amostra e CELT com 48, 96 e 192 kbps.

\footnotetext{
${ }^{1}$ http://www. wireshark.org/ - Acessado em Novembro de 2012.
} 


\section{Qualidade Sonora}

Para testar a qualidade sonora, duas abordagens são tipicamente utilizadas: podem ser realizados testes subjetivos ou objetivos. Em ambos os casos, existem técnicas específicas para qualificarmos um sinal de voz, já que este se trata de um caso especial em que a característica mais importante a ser avaliada é a inteligibilidade do sinal e, com isso, aspectos como a máxima frequência representada podem ser menores do que os de um sinal de áudio genérico. Por exemplo, o PESQ (Perceptual Evaluation of Speech Quality ou Avaliação Perceptual da Qualidade da Fala) [Sec03] é um método objetivo recomendado para uso na faixa de 300 a $3400 \mathrm{~Hz}$. No nosso caso, as técnicas para avaliação de qualidade sonora de voz não são tão relevantes e podem trazer resultados bons para casos em que não o som não é representado com qualidade suficientemente alta para música, o que exclui esses métodos do experimento realizado.

Dentre os tipos de testes subjetivos, temos as recomendações BS.1116-1 e BS.1534-1 da ITU-R [Ass97, Ass03], em que diversos participantes são escolhidos para quantificar a qualidade de áudio dentro de um ambiente controlado. A dificuldade de realização deste tipo de experimento se dá por causa da exigência de que os participantes possuam a capacidade de avaliar qualitativamente o áudio a ser analisado, além da necessidade de um número razoável deles para que os resultados obtidos sejam significativos. Nos testes subjetivos citados, cerca de 20 pessoas qualificadas são necessárias para que os resultados possam ser estatisticamente válidos. É importante frisar que para que uma pessoa seja considerada qualificada em uma metodologia deste tipo, é necessário que ela esteja acostumada a realizar este tipo de teste, tendo de ser capaz de identificar degradações sutis na qualidade de áudio e também conseguir avaliar qualitativamente estas pequenas pioras introduzidas pelos codificadores. Por esta razão, testes subjetivos não puderam ser realizados.

Para simplificar o processo de determinação da qualidade de áudio, também foram definidos métodos de análise objetiva como o PEAQ (Perceptual Evaluation of Audio Quality ou Avaliação Perceptual da Qualidade de Áudio) [Ass01], outra recomendação da ITU-R, em que é feita uma comparação entre um sinal de referência e a sua versão degradada (por causa da codificação utilizada, por exemplo), ambos estéreo, com amostras de 16 bits, taxa de $44,1 \mathrm{kHz}$ e alinhados no tempo, e o método devolve uma nota entre 0 e -4 que representa a diferença de qualidade entre as entradas e busca aproximar a escala utilizada em testes subjetivos (tabela 4.3).

\begin{tabular}{ll}
\hline Nota & Descrição \\
\hline 0 & Imperceptível \\
-1 & Perceptível mas não incômoda \\
-2 & Ligeiramente incômoda \\
-3 & Incômoda \\
-4 & Muito incômoda \\
\hline
\end{tabular}

Tabela 4.3: Escala utilizada no $P E A Q$

Um problema do PEAQ é a sua incapacidade de se adaptar a alguns tipos de cenários. Embora a correlação entre a nota reportada por este método objetivo com um teste subjetivo possa chegar a até 0,851 em um cenário de avaliação específico [Ass01], em outros casos, este valor pode cair para 0,489 [Kon12]. No caso de transmissão de áudio através de redes de computadores, em que existe a possibilidade de perda de pacotes, o PEAQ também apresenta dificuldades para classificar adequadamente a qualidade final obtida [HSV12, $\mathrm{PSR}^{+}$08, YXY09], o que levou ao desenvolvimento de novas técnicas, estendendo o PEAQ [MS09, YXY09].

Porém, alguns problemas existem ao lidarmos com estas abordagens: primeiramente, não existem implementações publicamente disponíveis destes modelos, impossibilitando que experimentos pudessem ser realizados sem a necessidade do desenvolvimento de uma aplicação com os algoritmos descritos nos artigos, fugindo do escopo proposto pro este trabalho. Além disso, não é possível garantir que os métodos propostos reflitam a qualidade do áudio sem a realização de testes subjetivos pois o 
método de redimensionamento de blocos de áudio proposto e implementado pelo JackTripMod possui características diferentes das usadas costumeiramente (silenciamento e repetição do áudio, como implementados no JackTrip original). Com isso, novamente nos encontramos em um cenário onde a realização de testes objetivos não é completamente adequada para avaliar a qualidade final do áudio transmitido.

Dada esta dificuldade de realização de testes subjetivos adequados, a solução adotada foi analisar a diferença de qualidade obtida entre os diversos codificadores utilizados nas aplicações discutidas no capítulo 3 através do PEAQ, porém desconsideramos os efeitos da perda de pacotes na qualidade do som. Para obter mais detalhes sobre este assunto, o leitor poderá encontrar discussões e resultados de experimentos subjetivos sobre a influência dos parâmetros da rede na percepção de qualidade do áudio pelo usuário em diversos trabalhos [HSV12, VHS07, EVHU+08].

\begin{tabular}{ll}
\hline Artista & Título \\
\hline Dave Matthews Band & Drunken Soldier \\
Dream Theater & Don't Look Past Me \\
Herbie Hancock & Spank-A-Lee \\
Marvin Gaye & What's Going On \\
Pink Floyd & Pigs On The Wing 1 \\
\hline
\end{tabular}

Tabela 4.4: Trechos de músicas selecionadas para o experimento utilizando o PEAQ

Os testes realizados consistiram no envio de trechos de dez segundos de cinco músicas (tabela 4.4) entre dois computadores conectados diretamente por um cabo de rede através de cada uma das aplicações, efetivamente permitindo que a latência fosse desprezível e a largura de banda disponível muito maior do que a disponível em uma conexão pela Internet. Isto foi escolhido para evitar que limitações forçassem o Skype a utilizar algum tipo de codificação que economizasse no uso de largura de banda já que não é possível realizar nenhum tipo de escolha manual neste software. Com isso, obtemos a maior qualidade possível pelo Skype. Os sinais de áudio transmitidos foram gravados por um terceiro computador e processados para que estes pudessem ser utilizados no programa PQevalAudio, uma implementação do PEAQ desenvolvida por membros da Universidade McGill que está disponível publicamente ${ }^{2}$. Embora existam outras implementações do PEAQ disponíveis, como o EAQUAL ${ }^{3}$ e o peaq $b^{4}$, estes deixaram de ser atualizados há muito tempo (2002 e 2003, respectivamente) enquanto a última versão do PQevalAudio é de 2010 e apresenta resultados muito próximos dos produzidos pela implementação de referência da ITU-R [dLFdJ $\left.{ }^{+} 08\right]$, apesar de que, ao contrário da especificação do PEAQ, o PQevalAudio seja otimizado para arquivos com taxas de amostragem de $48 \mathrm{kHz}$. Uma observação importante é que existem dois modos distintos do PEAQ, o básico e o avançado. Embora o modelo avançado traga melhores resultados, nenhuma das implementações publicamente disponíveis implementam tal modelo, apenas o modo básico que foi utilizado neste experimento.

\section{Latência}

O último aspecto interessante para ser explorado nos sistemas de transmissão de áudio através da rede é a latência. Diversas abordagens são possíveis, mas, neste trabalho, buscamos representar a latência real do sistema da placa de som e do sistema completo. Nas seções seguintes discutiremos como foram realizados os experimentos para que fosse possível efetuar tais medições.

Embora seja possível medir a latência da rede através do comando ping, a latência percebida pelo usuário depende de muitos outros fatores além da qualidade da rede envolvida. Tamanhos de buffer utilizados tanto pelo sistema operacional quanto pela aplicação usada para a performance musical distribuída e o tempo que é necessário para converter o áudio analógico para digital e vice-versa são

\footnotetext{
${ }^{2}$ http://www-mmsp.ece.mcgill.ca/documents/Software/ - Acessado em fevereiro de 2013.

${ }^{3}$ http://www.mp3-tech.org/programmer/sources/eaqual.tgz - Acessado em fevereiro de 2013.

${ }^{4}$ http://sourceforge.net/projects/peaqb/ - Acessado em fevereiro de 2013.
} 


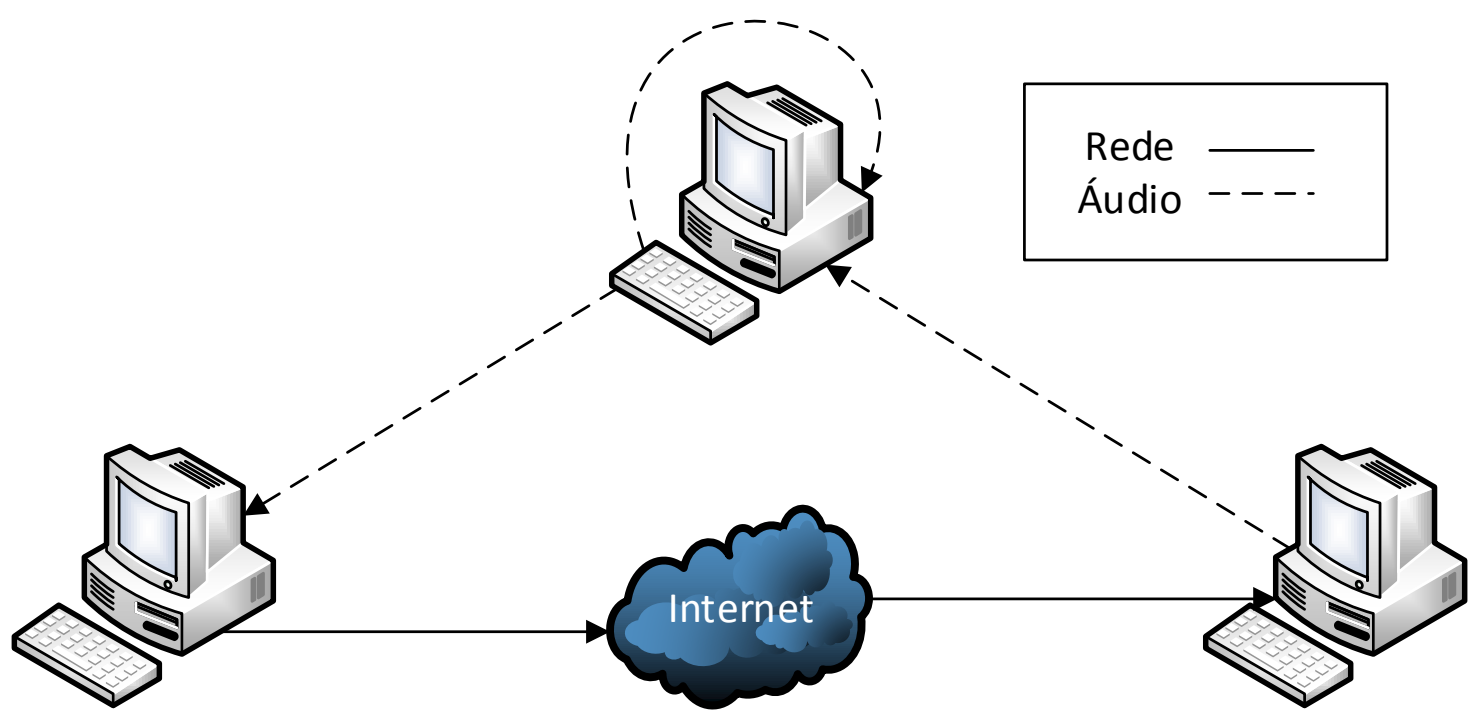

Figura 4.1: Estrutura utilizada para medição da latência do sistema

alguns dos fatores que influenciam na latência total do sistema. Idealmente, seriam efetuadas diversas medições independentes em cada um destes subsistemas e os seus resultados somados, porém, isso é impossível já que nem todos eles podem ser devidamente isolados. Assim, a opção viável passa a ser medir toda a cadeia envolvida no processo de transmissão de áudio pela rede e também os sistemas em que seja possível descobrir qual a sua participação no atraso total.

\section{Sistema Completo}

Para realizar a medição da latência do sistema como um todo, uma estrutura como a da fig. 4.1 foi montada. Nela, o computador 3 emite um sinal que será capturado por ele mesmo através de uma conexão de áudio do tipo loopback em um dos canais de captura de sua placa de som. Simultaneamente, este mesmo sinal é capturado pelo computador 1 e transmitido para o computador 2 através de uma rede local que possui um emulador de Internet chamado netem, capaz de simular uma conexão de rede que se comporta de forma semelhante à Internet. Assim que o computador 2 reproduz o sinal proveniente da rede através da placa de som, este mesmo sinal é novamente capturado pelo computador 3. Com isso, por meio da diferença temporal entre os dois canais capturados pelo computador 3 é possível medir a latência total do sistema, já que, em um canal o áudio é capturado diretamente e, em outro, existe o atraso introduzido por todos os sistemas envolvidos na comunicação via rede.

Como é necessária uma proximidade física entre os três computadores envolvidos na estrutura, pois eles estão conectados diretamente através de cabos de áudio analógico, o uso de um emulador de rede como o netem acaba sendo necessário. Idealmente, dois pontos de acesso à Internet distintos instalados em um mesmo local permitiriam uma representação mais real deste cenário, porém este tipo de infraestrutura não estava disponível para a realização deste experimento.

O netem é um componente que faz parte do núcleo do Linux desde as versões 2.6, integrando o pacote iproute2. Ele permite ao usuário configurar diversos aspectos da rede a ser emulada como latência, jitter, perda, duplicação, corrupção e reordenação de pacotes, dentre outras características. Experimentos realizados em [NR09, $\mathrm{H}^{+} 05$ ] mostram que a qualidade da emulação obtida por esta ferramenta é alta, embora não livre de problemas, e permite que cenários sejam reproduzidos em ambientes controlados, ainda que não seja possível emular simultaneamente todas as situações permitidas por uma rede tão dinâmica quanto a Internet.

Embora seja possível imaginar uma estrutura experimental semelhante à utilizada, mas com conexões virtuais entre as partes através do JACK ao invés de cabos de áudio físicos conectando os diversos dispositivos, esta solução exigiria que todas as aplicações testadas acessassem adequadamente o JACK, o que não é o caso do Skype nem do SoundJack. Apesar de podermos utilizar módulos do JACK para 


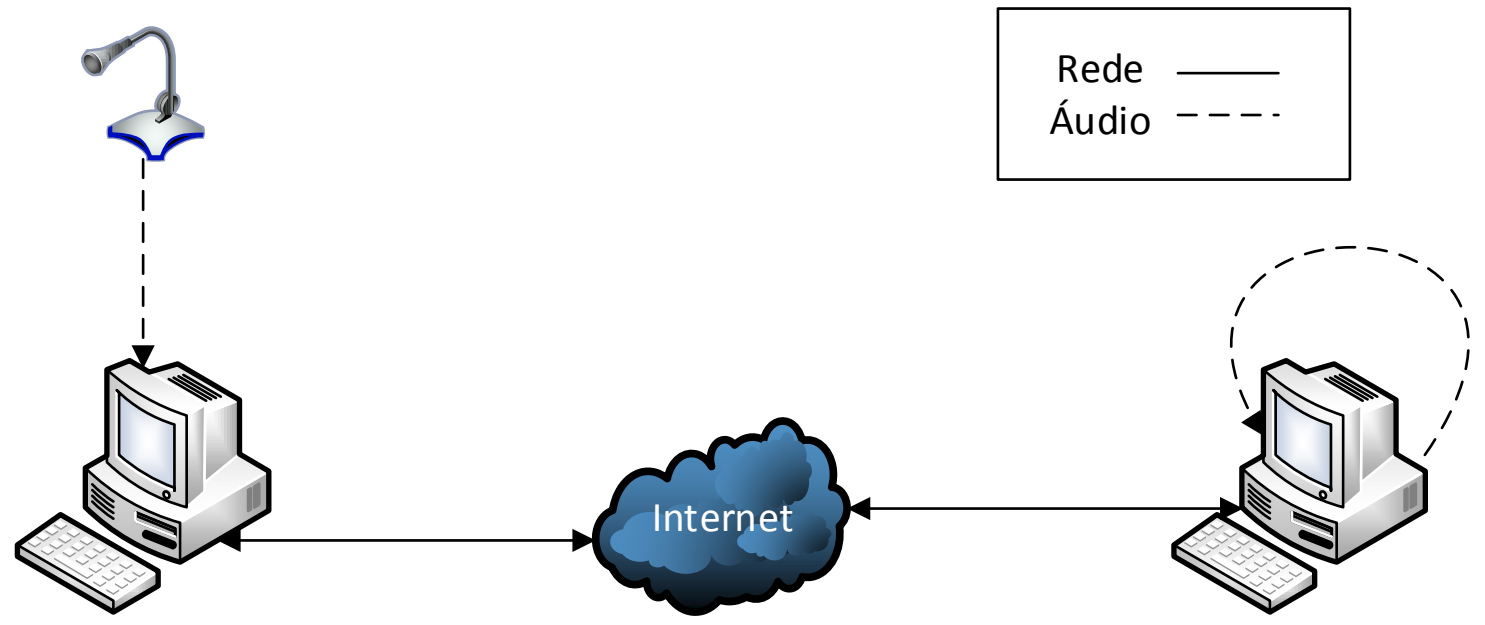

Figura 4.2: Estrutura alternativa para medição da latência do sistema

realizar a conexão com o ALSA e/ou o PulseAudio, não é possível determinar com precisão se algum tipo de atraso é introduzido com a utilização dos mesmos. Por isso, o uso de conexões físicas permite que todos os softwares testados utilizem a API de áudio mais apropriada para o seu caso sem que sistemas adicionais ocasionem desvios inesperados nas medições.

Outra alternativa seria a realização de um loopback de áudio em uma das máquinas, o que permitiria medir o tempo de ida e volta do sistema, como ilustrado na fig. 4.2. Esta estrutura tem a desvantagem de ser impossível medir o atraso de apenas um sentido da transmissão pela rede, o máximo que poderíamos fazer é estimar este valor através da metade do tempo medido de ida e volta, de forma similar ao que pode ser feito no ping. Porém, neste caso, não existe a necessidade de haver proximidade entre todas as máquinas utilizadas no experimento, permitindo que a própria Internet seja usada ao invés de um emulador de rede. Infelizmente, este tipo de estrutura não pôde ser utilizada pois o Skype possui um algoritmo de cancelamento de eco, como já dito anteriormente, o que impede que o áudio faça o loopback corretamente. Ao testarmos um cenário com esta configuraçao, o Skype apenas enviava silêncio como resposta para o primeiro computador ao invés do sinal de áudio original já que o sinal de entrada do loopback possuía grande similaridade com o sinal de saída, o que causava o cancelamento dos dois sinais e o envio de silêncio que foi observado.

Diversos cenários foram testados com o netem, variando jitter e perda de pacotes de acordo com os valores da tabela 4.5. Cada aplicação testada ainda utilizou as mesmas configurações do experimento para obter o uso de largura de banda (listadas na página 62) além de variar o tamanho do buffer quando configurável. Neste caso, SoundJack, JackTrip e JackTripMod obtiveram resultados com os buffers configurados com os valores indicados na tabela 4.5.

\begin{tabular}{llllll}
\hline Parâmetro & \multicolumn{3}{l}{ Valores } & & \\
\hline Jitter (ms) & 0 & 10 & 25 & 50 & \\
Perda de pacotes (\%) & 0 & 1 & 2 & 5 & \\
Tamanho de buffer & 2 & 5 & 10 & 15 & 20 \\
\hline
\end{tabular}

Tabela 4.5: Parâmetros utilizados para medição de latência do sistema

Em cada um dos cenários testados, um impulso unitário foi utilizado como sinal para medição de latência. O valor deste atraso foi obtido através do cálculo do máximo da correlação cruzada entre os dois canais de áudio gravados pelo computador 3 .

Nas configurações propostas, pode parecer estranho o não uso do parâmetro de latência do netem, porém, se nosso interesse é encontrar a latência total do sistema, introduzir um atraso constante na rede simplesmente desloca os resultados a serem obtidos também de forma constante, não produzindo nenhum efeito importante. 


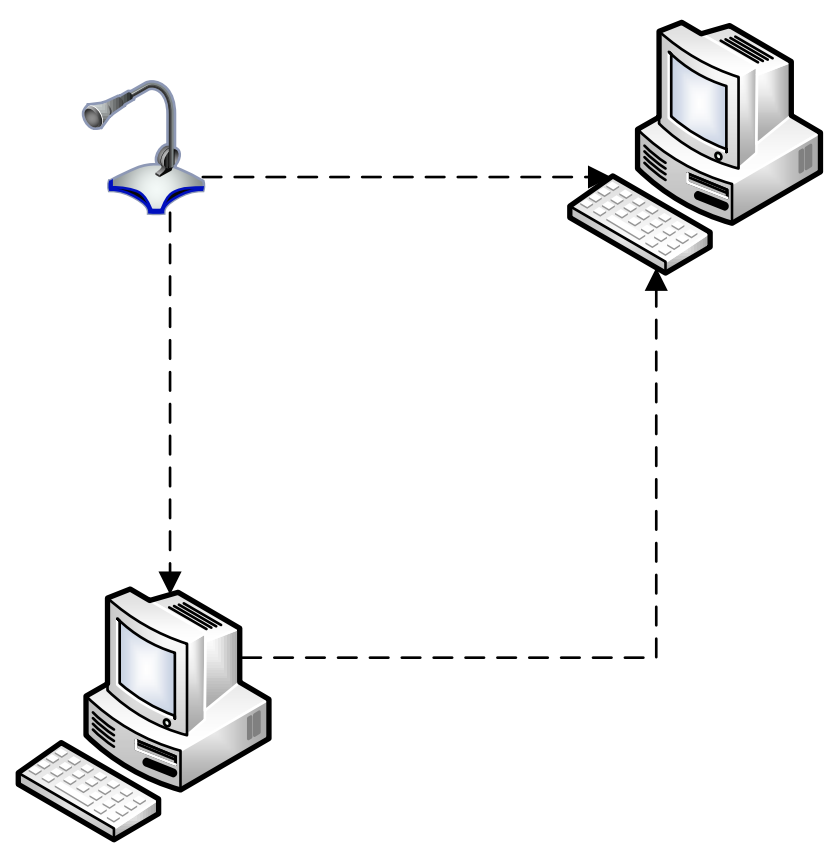

Figura 4.3: Estrutura para medição da latência da placa de som

Os valores de jitter e perda de pacotes testados tentaram exemplificar uma conexão de Internet brasileira real, baseando-se nos mesmos critérios utilizados em um estudo do Inmetro (Instituto Nacional de Metrologia, Qualidade e Tecnologia) que analisou diversos provedores em grandes centros brasileiros como São Paulo, Rio de Janeiro e Belo Horizonte [MKB12a, MKB12b, $\mathrm{CAM}^{+} 11$ ]. Os valores de referência utilizados nestes trabalhos são de no máximo $2 \%$ de perda de pacotes e $50 \mathrm{~ms}$ de jitter, dentre outras características da rede de menor relevância para a medição de latência, como a própria largura de banda disponibilizada. O experimento realizado extrapolou a quantidade de perda de pacotes, já que é interessante explorar cenários que não são comuns, mas o jitter máximo sugerido foi mantido por se considerar que tal valor já é excessivo em relação ao que é normalmente obtido.

\section{Placa de Som}

Uma vez que já possuímos a latência total do sistema, é interessante tentar desconstruir este resultado através da medição das latências de outros subsistemas envolvidos no processo. Embora isso não seja viável em todos os casos, é possível aproveitar uma estrutura semelhante à utilizada no experimento descrito anteriormente (fig. 4.1) para isolarmos o efeito da placa de som no atraso total. Podemos observar que esta configuração pode ser utilizada genericamente para qualquer tipo de medição de latência de áudio, apenas devemos conectar o dispositivo a ser testado no trecho inferior da ilustração (onde podemos encontrar os computadores 1 e 2 no exemplo anterior).

Assim, a estrutura utilizada neste experimento pode ser vista na fig. 4.3. As placas de som dos computadores 1 e 2 foram testadas com as taxas de amostragem 44100, 48000 e $96000 \mathrm{~Hz}$ e os tamanhos de bloco na forma $2^{n}$, em que $n \in\{4,5, \ldots, 12\}$. Como desejamos descobrir qual o tempo necessário para que os processos de conversão analógico-digital e digital-analógico sejam efetuados, não podemos utilizar as funcionalidades de monitoramento da placa de som que permitem que a entrada seja conectada diretamente à saída com latência desprezível. Para o teste realizado, o próprio JACK foi utilizado para realizar a conexão da entrada com a saída da placa de som, fazendo com que todo o processo de digitalização seja efetuado de forma similar à que é feita durante uma performance musical distribuída. Medições semelhantes foram realizadas em [WCZ04, WSR10], porém, os modelos de placas utilizadas não foram as mesmas que as existentes nos computadores deste experimento, logo, foi necessário realizar este procedimento para que fosse possível obter resultados relevantes para o experimento de latência do sistema. 


\subsection{Resultados}

Analisando as medições feitas com os experimentos, podemos observar as diversas similaridades entre as várias aplicações para performance musical distribuída e suas diferenças em relação a programas de VolP como o Skype, conforme discutido no capítulo 3.

\begin{tabular}{lllrrr}
\hline Programa & Codificador & Modo & Média (kbps) & Desvio padrão & Qualidade (PEAQ) \\
\hline Skype & SILK & - & 28,25 & 2,680 & $-3,482$ \\
SoundJack & OPUS & 48 kbps & 128,50 & 0,004 & $-1,072$ \\
& OPUS & $96 \mathrm{kbps}$ & 224,62 & 0,008 & $-0,852$ \\
& OPUS & $192 \mathrm{kbps}$ & 416,86 & 0,009 & $-0,745$ \\
& Linear & - & 1595,86 & 0,047 & $-0,734$ \\
JackTrip & PCM & 8 bits & 812,56 & 0,067 & $-2,732$ \\
& PCM & 16 bits & 1607,06 & 0,047 & $-0,706$ \\
& PCM & 24 bits & 2401,56 & 0,027 & $-0,721$ \\
& PCM & 32 bits & 3170,55 & 0,045 & $-0,721$ \\
JackTripMod & CELT & 48 kbps & 93,09 & 0,003 & $-2,505$ \\
& CELT & 96 kbps & 142,65 & 0,007 & $-1,183$ \\
& CELT & $192 \mathrm{kbps}$ & 241,02 & 0,006 & $-0,850$ \\
& PCM & 16 bits & 1607,76 & 0,024 & $-0,720$ \\
\hline
\end{tabular}

Tabela 4.6: Largura de banda utilizada

A largura de banda utilizada e a qualidade sonora associada a cada modo podem ser observadas na tabela 4.6. No JackTrip, a largura de banda usada é bastante alta devido à codificação PCM. Em seu modo de áudio mais econômico, são necessários 812 kbps, o que até tornaria viável uma performance musical distribuída em cidades brasileiras que dispõem de acesso à Internet banda larga de qualidade. Neste caso, porém, a queda na qualidade do áudio é grande, o que é bastante indesejado.

Em comparação, as aplicações que usam compactação de áudio com padrões como o CELT e o OPUS necessitam de uma largura de banda muito menor para que uma boa qualidade de áudio seja atingida. Mesmo utilizando em torno de $130 \mathrm{kbps}$, a qualidade final segundo a gradação utilizada pelo PEAQ é muito superior comparado aos mais de 800 kbps necessários para a transmissão de áudio descompactado.

Além disso, tanto o Sound Jack quanto o JackTripMod também oferecem a opção de se utilizar o padrão $P C M$, permitindo que, em cenários mais específicos que possuam uma alta largura de banda disponível, seja possível realizar uma performance musical distribuída de maior qualidade e, teoricamente, menor latência. Por exemplo, a largura de banda disponível em uma rede local ou em uma rede acadêmica internacional é suficientemente alta para que os cerca de 1,6 Mbps sejam transmitidos sem grandes dificuldades. Embora o Sound Jack não defina qual a resolução das amostras em seu modo linear, pelas características de uso de largura de banda ele aparenta utilizar 16 bits por amostra, o mesmo do padrão do CD de áudio.

Em casos extremos, o Skype pode se tornar uma opção interessante, já que seu uso de largura de banda é extremamente baixo, precisando apenas de cerca de um terço da banda necessária para a segunda menor opção testada, o CELT com somente $24 \mathrm{kbps}$ por canal de áudio. Considerando que o Skype se adapta às condições da rede, aumentando ou diminuindo a taxa de bits utilizada para a transmissão de voz, e que os experimentos foram realizados em uma rede local, em nenhum momento a aplicação se aproveitou da largura de banda extra disponível, mostrando que os $30 \mathrm{kbps}$ recomendados para a utilização da parte de comunicação de voz do programa, na verdade, determinam um limite superior do seu uso de largura de banda. Observando a qualidade sonora do codificador, fica claro que seu uso não é indicado para transmissões de alta fidelidade e que seu foco é apenas na codificação de voz, como já era esperado. 
Um fator importante a ser considerado é o custo de transmissão de cabeçalhos de pacotes de rede. Como pode ser visto na tabela 4.6, embora o Sound Jack ou o JackTripMod estejam configurados para uma codificação que use uma certa taxa de bits, a largura de banda necessária real é consideravelmente superior à escolhida pelo usuário. No caso de uma taxa de bits baixa, como $48 \mathrm{kbps}$, o cabeçalho dos pacotes de rede acabam ocupando grande parte do volume de dados transferido. Embora este tipo de comportamento também seja observado no JackTrip, como a largura de banda necessária neste programa já é alta, o overhead dos cabeçalhos não é tão significativo em relação aos dados de áudio transmitidos.

A medição feita também ilustra outra diferença entre as opções disponibilizadas pelo Sound Jack e pelo JackTripMod: enquanto o primeiro utiliza, por exemplo, 48 kbps para cada canal de áudio, o último expõe para o usuário a quantidade total de bits por segundo a ser transmitida. Isso resulta na diferença de qualidade observada entre os dois programas, já que o pareamento não é perfeito. $O$ modo do Sound Jack que usa o OPUS a 48 kbps utiliza essa taxa de bits para cada canal transmitido, enquanto o modo chamado de CELT a 96 kbps no JackTripMod indica a taxa utilizada para todos os canais combinados. Levando estes fatores em consideração, embora o OPUS seja uma versão mais atualizada do CELT, a qualidade dos dois compactadores é bastante próxima, dado que a taxa de bits utilizada também seja.

É interessante observar que as versões de áudio PCM não obtiveram uma nota perfeita. Uma possível explicação para este fato é que o áudio testado passou por diversas etapas de conversão de resolução de amostra neste percurso. $O$ arquivo de teste utilizado no experimento foi codificado com amostras de 16 bits, mesma resolução dos trechos originais retirados dos CDs das músicas utilizadas. Inicialmente é realizada uma etapa de conversão digital-analógica quando o áudio é emitido pela placa de som do computador 3 e uma analógico-digital ao ser capturado pela placa de som do computador 1. No caso do JackTrip, o uso do JACK como API de áudio faz com que o áudio seja convertido para amostras de ponto flutuante 32 bits independentemente do formato utilizado pela placa de som (normalmente 16 ou 24 bits por amostra), ocasionando mais uma etapa de requantização. Ao ser transmitido pelo JackTrip, mais uma conversão ocorre quando o usuário opta pelo uso de amostras de 16 ou 24 bits (no caso de envio de áudio a 32 bits não é realizado nenhum tipo de processamento). Ao ser recebido pelo computador 2, o áudio é novamente convertido pelo JackTrip para as amostras de 32 bits utilizadas pelo JACK. Por último, mais conversões digital-analógica e analógico-digital são realizadas para gravarmos o sinal reproduzido pelo computador 2 no computador 3 . Dada a quantidade de transformações sendo realizadas, não é de se espantar que haja algum tipo de degradação no sinal ao final do processo e que o algoritmo utilizado no PEAQ detecte alguma diferença de qualidade em relação ao áudio original. Também é importante notar que o resultado das opções com 24 e 32 bits por amostra acabou sendo ligeiramente inferior em relação ao PCM 16 bits, o que é inesperado. Dentre as possíveis causas para este resultado, podemos citar as conversões entre 16 bits inteiros do arquivo original para os 32 bits de ponto flutuante utilizados pelo JACK, a função de requantização para 24 bits implementada pelo JackTrip e, o que é mais provável, apenas variações introduzidas pelo caminho analógico de áudio utilizado no experimento.

Embora em teoria o uso de codificadores como o CELT e o OPUS introduzam uma latência algorítmica nos sistemas em relação ao uso do padrão PCM, na prática, os atrasos adicionais se tornam insignificantes, como pode ser observado na tabela 4.7. No nosso experimento, era esperado que o CELT e o OPUS adicionassem cerca de 2,67 ms pois a latência algorítmica destes codificadores é de metade do tamanho do bloco utilizado (512 amostras, no caso). Porém, o que foi observado é que é possível obter variações desta magnitude mesmo utilizando-se o mesmo tipo de codificação, como pode ser visto nas latências observadas nos diferentes modos do JackTrip e nos modos OPUS do Sound Jack, indicando que o comportamento da aplicação depende também de outros fatores dos sistemas envolvidos. Por exemplo, a necessidade do sistema operacional de gerenciar os recursos a serem compartilhados entre diversos processos diferentes pode ocasionar tais variações nos resultados observados. 


\begin{tabular}{lrrr}
\hline Aplicação & Codificador & Modo & Latência média $(\mathrm{ms})$ \\
\hline JackTrip & PCM & 8 bits & 95,74 \\
& PCM & 16 bits & 97,03 \\
& PCM & 24 bits & 96,50 \\
\multirow{5}{*}{ JackTripMod } & PCM & 32 bits & 94,74 \\
& CELT & 48 kbps & 84,06 \\
& CELT & $96 \mathrm{kbps}$ & 84,46 \\
& CELT & $192 \mathrm{kbps}$ & 84,85 \\
SoundJack & PCM & 16 bits & 81,36 \\
& OPUS & $48 \mathrm{kbps}$ & 171,22 \\
& OPUS & $96 \mathrm{kbps}$ & 169,86 \\
& OPUS & $192 \mathrm{kbps}$ & 171,14 \\
& Linear & - & 168,21 \\
\hline
\end{tabular}

Tabela 4.7: Comparação de latência entre diversos codificadores

Nas tabelas 4.8 até 4.11 podemos analisar as latências médias do sistema em cada um dos programas testados utilizando a codificação PCM 16 bits quando aplicável.

\begin{tabular}{llrrrrr}
\hline \multirow{2}{*}{ Jitter } & Perda de & \multicolumn{2}{l}{ Tamanho de buffer } & & \\
& pacotes $(\%)$ & 2 & 5 & 10 & 15 & 20 \\
\hline 0 & 0 & 46,78 & 71,03 & 119,75 & 120,15 & 127,45 \\
& 1 & 39,35 & 38,51 & 47,72 & 46,88 & 52,34 \\
& 2 & 38,75 & 39,34 & 38,52 & 38,08 & 44,43 \\
& 5 & 38,81 & 38,74 & 39,15 & 42,61 & 39,56 \\
10 & 0 & 56,91 & 71,79 & 114,3 & 135,46 & 141,56 \\
& 1 & 56,53 & 58,26 & 64,37 & 64,22 & 61,3 \\
& 2 & 56,85 & 59,52 & 58,83 & 57,96 & 61,58 \\
& 5 & 56,37 & 56,57 & 56,2 & 57,26 & 60,25 \\
25 & 0 & 80,24 & 89,5 & 100,71 & 156,46 & 165,79 \\
& 1 & 79,73 & 88,3 & 87,84 & 89,98 & 89,93 \\
& 2 & 79,2 & 86,93 & 85,49 & 84,5 & 86,59 \\
& 5 & 80,28 & 87,09 & 86,76 & 86,13 & 87,22 \\
50 & 0 & 126,45 & 134,31 & 142,71 & 201,72 & 209,29 \\
& 1 & 120,76 & 128,69 & 136,87 & 135,04 & 133,85 \\
& 2 & 118,75 & 133,58 & 134,71 & 135,36 & 134,75 \\
& 5 & 114,84 & 128,35 & 130,9 & 132,34 & 135,06 \\
\hline
\end{tabular}

Tabela 4.8: Latências médias obtidas com o JackTrip

Dentre todos os softwares, o JackTrip é o que obtém as menores latências em geral, porém, isso se deve à forma com a qual o seu gerenciamento de buffer atua, como discutido na seção 3.1.3. Podemos observar que, quando não há perda de pacotes, as latências aumentam juntamente com o tamanho do buffer, como esperado. Porém, no momento em que perdas de pacotes são introduzidas na emulação da rede, a ausência de alguns pacotes causam o esvaziamento do buffer e, por não aguardar o buffer ser preenchido novamente antes de reiniciar a reprodução do áudio, o efeito final é de que o tamanho do buffer influencia pouco na medida de latência do sistema.

Embora também seja possível observar latências menores no SoundJack quando há perda de pacotes na transmissão pela rede, as diferenças são muito menos drásticas do que no JackTrip, e estão 


\begin{tabular}{llrrrrr}
\hline \multicolumn{1}{c}{ Jitter } & Perda de & \multicolumn{2}{l}{ Tamanho de buffer } & & \\
& pacotes (\%) & 2 & 5 & 10 & 15 & 20 \\
\hline 0 & 0 & 79,32 & 113,12 & 166,51 & 218,62 & 271,99 \\
& 1 & 75,65 & 92,82 & 101,1 & 165,19 & 213,07 \\
& 2 & 75,34 & 93,67 & 124,64 & 126,5 & 144,24 \\
& 5 & 73,49 & 93,08 & 111,97 & 161,06 & 178,42 \\
10 & 0 & 90,74 & 122,77 & 178,02 & 230,47 & 282,23 \\
& 1 & 92,15 & 109,12 & 122,3 & 167,48 & 210,54 \\
& 2 & 92,57 & 107 & 138,14 & 164,45 & 170,2 \\
& 5 & 92,71 & 104,98 & 143,16 & 184,91 & 174,14 \\
25 & 0 & 115,71 & 133,02 & 186,94 & 240,2 & 294,7 \\
& 1 & 117,59 & 135,45 & 158,38 & 166,13 & 219,18 \\
& 2 & 117,48 & 134,21 & 152,07 & 182,23 & 185,06 \\
& 5 & 115,28 & 135,85 & 149,3 & 209,65 & 250,17 \\
50 & 0 & 165,95 & 173,47 & 210,36 & 267,96 & 319,94 \\
& 1 & 154,83 & 175,94 & 199,53 & 220,16 & 248,19 \\
& 2 & 162,54 & 177,89 & 209,33 & 232,31 & 291,75 \\
& 5 & 166,46 & 172,89 & 200,92 & 210,59 & 257,72 \\
\hline
\end{tabular}

Tabela 4.9: Latências médias obtidas com o Sound Jack

de acordo com o que seria esperado já que os pacotes que não foram entregues acabam ocasionando vazios na reprodução do áudio, diminuindo a latência obtida a cada ocorrência deste tipo.

\begin{tabular}{lrrrr}
\hline $\begin{array}{l}\text { Perda de } \\
\text { Pacotes (\%) }\end{array}$ & 0 & 10 & 25 & 50 \\
\hline 0 & 160,05 & 172,50 & 190,48 & 352,05 \\
1 & 162,15 & 174,26 & 186,80 & 372,26 \\
2 & 163,77 & 174,35 & 197,81 & 894,55 \\
5 & 420,01 & 176,62 & 434,26 & 393,31 \\
\hline
\end{tabular}

Tabela 4.10: Latências médias obtidas com o Skype

No caso do Skype, o usuário não possui nenhum controle sobre o tamanho do buffer que será utilizado durante a transmissão. Podemos observar que, na maior parte dos casos, o jitter e a perda de pacotes da rede não possuem grande influência sobre a latência total do sistema, ficando em torno de 160 a 200 ms. Porém, em alguns casos, a latência observada chega a valores bastante altos e completamente inviáveis para uma interação em tempo real. Outro aspecto a ser observado é que, mesmo no caso ótimo, em que não há perda de pacotes nem jitter da rede, o Skype introduz uma latência consideravelmente alta para a realização de performances musicais distribuídas, mas dentro do esperado para que seja possível que pessoas conversem entre si, como já discutido anteriormente. Estes resultados, juntamente com a baixa qualidade de codificação de áudio obtida, indicam que o Skype, apesar de ser uma ótima ferramenta de VoIP, não é uma boa alternativa para a realização de performances musicais distribuídas.

O JackTripMod obteve resultados que ilustram algumas características do funcionamento do buffer implementado. Com base nas heurísticas utilizadas, temos que o tamanho real escolhido automaticamente para o buffer depende diretamente do jitter observado na rede e é por isso que podemos ver que as latências medidas aumentam conforme o jitter e o tamanho do buffer escolhido crescem. Porém, esse comportamento não é observado quando não há perda de pacotes na rede. Isso ocorre pois o buffer é inicializado com um tamanho que depende da escolha do usuário, porém, seu 


\begin{tabular}{llrrrrr}
\hline \multirow{2}{*}{ Jitter } & Perda de & \multicolumn{2}{l}{ Tamanho de buffer } & & \\
& pacotes (\%) & 2 & 5 & 10 & 15 & 20 \\
\hline 0 & 0 & 79,81 & 80,31 & 81,69 & 82,24 & 82,73 \\
& 1 & 52,19 & 50,61 & 50,74 & 55,09 & 59,58 \\
& 2 & 51,41 & 54,46 & 67,96 & 52,48 & 69 \\
& 5 & 56,13 & 60,89 & 67,24 & 83,67 & 94,46 \\
10 & 0 & 91,11 & 93,46 & 92,39 & 87,6 & 97,74 \\
& 1 & 73,09 & 80,3 & 93,68 & 109,71 & 141,62 \\
& 2 & 75,43 & 77,56 & 95,34 & 119,8 & 102,26 \\
& 5 & 73,82 & 82,34 & 105,84 & 109,87 & 164,89 \\
25 & 0 & 120,45 & 115,89 & 115,77 & 117,72 & 118,34 \\
& 1 & 105,24 & 119,69 & 124,74 & 194,4 & 225,76 \\
& 2 & 99,77 & 105,68 & 159,43 & 133,67 & 160,91 \\
& 5 & 102,62 & 133,04 & 172,98 & 172,72 & 203,12 \\
50 & 0 & 165,47 & 155,52 & 149,44 & 165,76 & 157,35 \\
& 1 & 155,58 & 174,59 & 204,75 & 239,58 & 355,59 \\
& 2 & 156,27 & 178,23 & 202,7 & 262,24 & 300,57 \\
& 5 & 139,54 & 188,97 & 197,18 & 193,08 & 339,24 \\
\hline
\end{tabular}

Tabela 4.11: Latências médias obtidas com o JackTripMod

tamanho real apenas será modificado quando ocorrer um esvaziamento do buffer e for necessário aguardar até que haja uma quantidade de dados suficiente para que o áudio volte a ser reproduzido. Nos cenários em que não há perda de pacotes, essas esvaziamentos acabam ocorrendo e, por isso, a variação medida é pequena.

\begin{tabular}{lrrrrrr}
\hline $\begin{array}{l}\text { Tamanho } \\
\text { do bloco }\end{array}$ & ALC262 & \multicolumn{5}{c}{ ALC889A } \\
\hline 16 & $* 1,01$ & $* 0,93$ & $* 0,64$ & $* 1,08$ & $* 0,99$ & $* 0,49$ \\
32 & $* 1,02$ & $* 0,93$ & $* 0,80$ & $* * 1,76$ & $* * 349,08$ & $* * 4,50$ \\
64 & $* * 1,74$ & $* * 1,60$ & $* 0,80$ & - & - & 0,83 \\
128 & 3,19 & 2,93 & $* * 1,54$ & 3,24 & 3,00 & 1,48 \\
256 & 6,09 & 5,60 & 2,81 & 6,15 & 5,65 & 2,81 \\
512 & 11,90 & 10,93 & 5,47 & 11,95 & 10,98 & 5,48 \\
1024 & 23,51 & 21,61 & 10,81 & 23,56 & 21,66 & 10,83 \\
2048 & 46,73 & 42,93 & 21,47 & 46,78 & 42,98 & 21,49 \\
4096 & 93,17 & 85,61 & 42,80 & 93,22 & 85,65 & 42,82 \\
\hline
\end{tabular}

Tabela 4.12: Latência da placa de som (ms)

Na tabela 4.12 estão as medições de latência realizadas nas placas de áudio utilizadas nestes experimentos. Os resultados marcados com $(*)$ indicam as ocasiões em que foram observados erros do tipo xrun no JACK. Este tipo de erro indica que o equipamento utilizado não possui condições para utilizar tal configuração, fazendo com que os buffers de áudio do JACK acabem ficando vazios ou cheios demais ${ }^{5}$ por não ser possível manter um fluxo de dados constante entre a placa de som e a memória do computador, ocasionando falhas na reprodução e/ou captura do áudio. Nos resultados marcados com $(* *)$, problemas de incompatibilidade entre a placa de som utilizada e o próprio JACK foram

\footnotetext{
${ }^{5} \mathrm{O}$ termo xrun deriva justamente dos termos buffer underrun e overrun, que significam esvaziamento e enchimento excessivo, em inglês.
} 


\begin{tabular}{lrrrrrr}
\hline $\begin{array}{l}\text { Tamanho } \\
\text { do bloco }\end{array}$ & ALC262 & \multicolumn{7}{c}{ ALC889A } \\
\hline 16 & $* 0,65$ & $* 0,60$ & $* 0,47$ & $* 0,72$ & $* 0,66$ & $* 0,32$ \\
32 & $* 0,29$ & $* 0,26$ & $* 0,47$ & $* * 1,03$ & $* * 348,41$ & $* * 4,17$ \\
64 & $* * 0,29$ & $* * 0,27$ & $* 0,13$ & - & - & 0,16 \\
128 & 0,29 & 0,26 & $* * 0,21$ & 0,34 & 0,33 & 0,15 \\
256 & 0,29 & 0,27 & 0,14 & 0,35 & 0,32 & 0,14 \\
512 & 0,29 & 0,26 & 0,14 & 0,34 & 0,31 & 0,15 \\
1024 & 0,29 & 0,28 & 0,14 & 0,34 & 0,33 & 0,15 \\
2048 & 0,29 & 0,26 & 0,14 & 0,34 & 0,31 & 0,16 \\
4096 & 0,29 & 0,28 & 0,13 & 0,34 & 0,31 & 0,15 \\
\hline
\end{tabular}

Tabela 4.13: Latência adicional em relação ao JACK (ms)

observados. Enquanto os resultados marcados com $(*)$ registravam algumas dezenas de xruns durante a execução do JACK, estas outras configurações emitiam milhares de erros deste tipo, impossibilitando completamente o uso do equipamento de áudio. Em alguns casos, o problema observado foi ainda mais crítico, já que nem era possível fazer com que o JACK fosse executado; estes casos não possuem nenhum resultado registrado na tabela.

O experimento realizado possibilitava a medição simultânea, mas não independente, das latências de entrada e saída de áudio das placas utilizadas. Os resultados da tabela 4.12 indicam uma estimativa de quanto cada processo contribuiu para a latência medida. Em outras palavras, estes valores indicam a latência de reprodução ou captura dependendo do tamanho de bloco selecionado.

A latência teórica do JACK pode ser calculada em milissegundos através da seguinte fórmula:

$$
1000 \times \frac{\text { tamanho de bloco }}{\text { taxa de amostragem }}
$$

A tabela 4.13 mostra a diferença entre o valor medido e este valor teórico configurado no JACK. Felizmente, esta diferença é bastante pequena, menor do que 0,5 ms, e é praticamente constante e independente do tamanho de bloco escolhido, permitindo que o usuário confie nos valores estimados pelo JACK para a configuração de seu equipamento.

Com os dados destas tabelas é possível analisar alguns aspectos da latência total do sistema e obter novas perspectivas sobre os sistemas envolvidos. Podemos notar, por exemplo, que a menor latência observada durante o experimento foi de cerca de $38 \mathrm{~ms}$ com o JackTrip, valor maior do que o determinado pelo limiar de performance em conjunto. Durante os experimentos, o JACK foi configurado para utilizar blocos de 512 amostras e taxa de amostragem de $48 \mathrm{kHz}$. Destes $38 \mathrm{~ms}$, podemos considerar que cerca de $22 \mathrm{~ms}$ foram causados pelas placas de som envolvidas $(\approx 11 \mathrm{~ms}$ para captura e outros $\approx 11 \mathrm{~ms}$ para a reprodução). Temos então que são necessários em torno de 16 ms para que um pacote contendo áudio seja enviado pelo sistema operacional através de uma rede que possui latência praticamente zero, indicando que existem outros processos envolvidos que não estão sendo contabilizados adequadamente.

Supondo que esses $16 \mathrm{~ms}$ de atraso sejam constantes e façam parte do sistema operacional, não podendo ser eliminados, e supondo que poderíamos escolher qualquer tamanho de bloco em que não houve xrun para a realização de uma performance musical distribuída ${ }^{6}$, teríamos um mínimo de 18 ms, sobrando apenas $7 \mathrm{~ms}$ para que seja possível uma performance dentro do limiar de performance em conjunto, sob o modelo de interação realística. Dentro destas condições, os cenários possíveis para que este modelo de performance musical pela rede seja viável se torna bastante restrito, indicando que uma solução como o modelo de retorno atrasado possa ser uma alternativa que permita a realização

\footnotetext{
${ }^{6}$ Isto não é necessariamente verdade já que os experimentos de latência de placa de som foram realizados com o equipamento dedicado apenas para tal finalidade. Assim que mais processos passam a realizar algum tipo de carga sobre o sistema operacional, as chances de que erros de xruns ocorram passam a ser maiores.
} 
de performances musicais distribuídas em condições não ideais de latência.

Os resultados dos experimentos realizados mostram como o Sound Jack e o JackTripMod possuem características semelhantes dentro dos cenários testados, atingindo um balanço entre alta qualidade, baixa latência e baixa utilização de largura de banda, enquanto o Skype peca nos dois primeiros quesitos mas se sobressai no terceiro e o JackTrip é inadequado para que usuários caseiros utilizem a ferramenta devido ao seu uso de áudio sem compactação e a alta largura de banda exigida associada a esta característica. 


\section{Capítulo 5}

\section{Conclusão e Trabalhos Futuros}

O JackTripMod se impõe como uma boa alternativa para a realização de performances musicais distribuídas. Através de um codificador de alta eficiência e baixa latência, como o CELT, uma das maiores dificuldades da utilização do projeto original por usuários caseiros foi solucionada. Mesmo na realidade brasileira, em que as taxas de upload oferecidas pelos provedores de acesso são baixas, a realização de performances musicais de alta qualidade pela Internet passa a ser uma opção viável.

Também destaca-se a adição do modelo de retorno atrasado, possibilitando ao músico uma abordagem que antes não era possível para as performances musicais distribuídas através do JackTrip, fazendo do JackTripMod uma solução bastante abrangente em relação às abordagens de acpNMP, que somente não implementa o modelo do tempo falso para o usuário já que este é um modelo completamente diferente dos outros, tendo apenas o NINJAM como exemplo de uma ferramenta funcional deste tipo de abordagem.

As outras novas funcionalidades adicionadas ao JackTrip também abrem novos caminhos a serem explorados musicalmente:

- A divisão de pacotes de rede em tamanhos menores do que os blocos de áudio utilizados pela placa de som permite a transmissão de um número de canais muito maior do que o que era possivel anteriormente;

- Usuários com os mais diversos equipamentos podem começar a interagir musicalmente, sendo que cada participante pode decidir qual será a sua configuração utilizada independentemente das escolhas tomadas pelas outras partes;

- O novo modelo de tratamento dos buffers oferece diferentes alternativas tanto para os casos em que há um enchimento demasiado do buffer quanto quando não há áudio a ser reproduzido devido a falhas de transmissão na rede;

- A possibilidade de se conectar a mais de um participante por processo e a sincronia entre todas as partes permite que sejam experimentados novos espaços musicais, conectando simultaneamente diversos locais fisicamente distantes;

- A integração com a libpurple e a adição de uma interface gráfica permitem que usuários menos experientes com o uso de linhas de comando em terminais possam realizar uma performance musical distribuída com menos dificuldade.

Mesmo quando comparado ao SoundJack, que possui diversas funcionalidades semelhantes às oferecidas pelo JackTripMod, ainda é possível observar vantagens introduzidas pelo projeto desenvolvido:

- O fato do SoundJack não oferecer publicamente o código fonte impossibilita que extensões sejam feitas na aplicação, limitando a sua flexibilidade;

- Ao não disponibilizar mais a opção para a utilização do servidor de áudio JACK, diversas possibilidades de integração entre os diversos softwares de música existentes para computadores 
se tornam menos acessíveis. Por exemplo, caso seja desejado utilizar o Pd durante a performance, ele deverá ser conectado ao computador através de um dispositivo externo, enquanto que, caso fosse possível o uso do JACK, bastaria conectar ambas as aplicações através das conexões virtuais implementadas pelo servidor de áudio;

- Embora seja possível realizar performances musicais distribuídas dentro do modelo de retorno atrasado com o SoundJack, o usuário precisa configurar manualmente o atraso (fixo) desejado, em contraste ao método automático e dinâmico introduzido pelo JackTripMod;

- Impossibilidade de escolha, no SoundJack, da taxa de amostragem a ser utilizada, e impossibilidade de transmissão de mais do que dois canais de áudio

- O SoundJack permite apenas silenciar a reprodução do áudio quando há um esvaziamento de buffer, em contraste com as diversas técnicas permitidas pelo JackTripMod.

Apesar disso, o Sound Jack também oferece vantagens. A codificação utilizada é baseada no OPUS, que é essencialmente uma versão mais recente do CELT. Embora a qualidade obtida seja melhor, não existem diferenças muito significativas. Outra vantagem é a utilização ligeiramente menor de largura de banda devido a um overhead menor em comparação ao obtido no JackTripMod.

O Skype, em comparação às soluções para a realização de performances musicais distribuídas, ilustra as diferenças entre aplicações musicais e de voz. Enquanto a qualidade de áudio obtida é suficientemente alta para permitir conversações inteligíveis, a mesma não é alta o bastante para a transmissão de música. Associado a esse problema, a latência obtida pela aplicação, mesmo em cenários ideais, não é baixa o suficiente para a seu uso em performances musicais distribuídas. O programa também peca na flexibilidade de configuração, não permitindo muitas escolhas para o usuário.

Assim, cabe ao usuário pesar as vantagens e desvantagens de cada alternativa para o uso desejado e escolher aquele que é mais adequado para o cenário em que ele se encontra. O Sound Jack possui diversas características que o tornam interessante para a realização de performances musicais distribuídas em ambientes caseiros. O JackTrip é muito mais focado para o uso acadêmico, oferecendo soluções compatíveis com a infraestrutura oferecida neste meio. O JackTripMod expande tudo aquilo que o JackTrip oferece, adicionando soluções para o seu uso em ambientes caseiros, o que o torna a ferramenta com maior flexibilidade de configuração dentre as analisadas neste projeto.

Futuramente, podemos trabalhar com vários aspectos dentro da área de performance musical distribuída. O papel cada vez maior do acesso à Internet sem fio no cotidiano pede uma exploração mais detalhada da performance deste tipo de conexão em aplicações que exigem interatividade em tempo real. Durante o desenvolvimento deste projeto, testes informais foram realizados utilizando uma conexão $3 \mathrm{G}$ e os resultados obtidos não foram muito animadores, ocorrendo grande quantidade de falhas na reprodução do áudio mesmo com o uso de buffers bastante generosos, indicando ser necessária uma abordagem diferente no caso da Internet através de conexões sem fio.

De forma similar, a proliferação cada vez maior de smartphones sugere que seja interessante criar aplicações semelhantes às desenvolvidas em sistemas operacionais para dispositivos móveis como o Android/iOS/Windows Phone. O desempenho destes equipamentos quando acessando redes sem fio teria de ser avaliado ( $3 \mathrm{G} \mathrm{e} \mathrm{WiFi),} \mathrm{assim} \mathrm{como} \mathrm{os} \mathrm{níveis} \mathrm{de} \mathrm{latência} \mathrm{obtidos} \mathrm{pelos} \mathrm{subsistemas} \mathrm{de}$ áudio disponibilizados. Experimentos semelhantes aos feitos neste projeto teriam de ser realizados para averiguar a viabilidade deste tipo de aplicação nestes dispositivos.

Desenvolvimentos recentes também abrem a possibilidade de implementação de uma aplicação para a realização de performances musicais distribuídas diretamente através do navegador de Internet utilizado pelo usuário através do projeto WebRTC ${ }^{1}$, atualmente implementado no Google Chrome e no Mozilla Firefox, que já oferece diversas funcionalidades para a comunicação em tempo real como o protocolo ICE para o atravessamento de NATs e suporte a uma variedade de codificadores de áudio e vídeo, incluindo nesta lista o próprio OPUS. Novamente, teria de ser analisada a latência do subsistema de áudio envolvido no processo para confirmar a viabilidade de performances musicais distribuídas.

\footnotetext{
${ }^{1}$ http://www.webrtc.org/ - Acessado em fevereiro de 2013.
} 
Caso haja algum tipo de suporte a APIs de baixa latência, como o ASIO em plataformas Windows, por exemplo, uma aplicação deste tipo não exigiria nem que o usuário realizasse a instalação de um novo programa em seu computador, bastando um navegador que implemente esta tecnologia.

Novas funcionalidades também poderiam ser adicionadas ao próprio JackTripMod. Por exemplo, a transmissão simultânea de vídeo e áudio através da aplicação permitiria um novo nível de interação entre as partes conectadas. Um problema seria decidir entre o aumento da latência total percebida ou uma assincronia entre áudio e vídeo, já que a captura de vídeo normalmente possui um atraso maior do que o observado no caso do áudio. Experimentos teriam de ser realizados com usuários para analisar qual seria o método mais adequado.

Uma característica que não traria grandes dificuldades de ser implementada é o uso do codificador OPUS, bastando limitar o seu uso às taxas de amostragem aceitas. Outra possibilidade seria implementar módulos que realizassem a reamostragem do sinal quando necessário, permitindo assim que o OPUS se tornasse viável independentemente da configuração utilizada. Isso ainda traria como benefícios a possibilidade de cada usuário utilizar uma taxa de amostragem diferente em uma mesma performance musical distribuída quando desejado.

O uso do RtAudio no JackTripMod precisa ser reavaliado, já que diversas funcionalidades implementadas exploram características que somente são oferecidas pelo JACK. Embora seja possível ainda utilizar o RtAudio na maior parte das configurações, alguns modos oferecidos atualmente exigem o uso do JACK para seu correto funcionamento. Para que o RtAudio funcione adequadamente nestes casos, seria necessário simular o comportamento do JACK, o que pode parecer um esforço duplicado com poucas vantagens observáveis na prática.

Outro aspecto importante de ser investigado é descobrir se os $16 \mathrm{~ms}$ de latência obtidos durante os experimentos, que não estavam relacionados nem aos atrasos da rede nem ao do áudio, são passíveis de serem reduzidos. Isso traria benefícios para a realização de performances musicais distribuídas com usuários mais distantes entre si. Conforme foi relatado, atualmente, a transmissão pela rede deve levar no máximo $7 \mathrm{~ms}$ para que seja possível o modelo de interação realística. Isso equivale a 1470 $\mathrm{km}$ de distância, valor bastante inferior aos $5250 \mathrm{~km}$ possíveis em um cenário ideal. Outro ponto de vista deste problema é imaginar que esses 16 ms gastos em processos desconhecidos equivalem a uma distância de $3360 \mathrm{~km}$ se fosse realizada uma transmissão de dados através de cabos de fibra ótica, ou seja, o tempo que leva para um dado ser enviado em linha reta de São Paulo até Lima, no Peru, é aproximadamente o mesmo que o tempo necessário para que os dados do buffer de uma placa de som de um computador cheguem até o buffer de reprodução da placa de som do segundo computador.

Também devemos levar em conta que a tendência da Internet residencial é sempre aumentar a largura de banda disponível para os usuários. Apesar disso potencialmente tornar a codificação de áudio desnecessária, temos exemplos de que a utilização de compactadores eficientes e de alta qualidade tornou o interesse por áudio descompactado muito baixo. Em tempos em que a largura de banda disponível em muitas residências é suficiente para a transmissão de áudio compactado sem perdas como o FLAC ou até mesmo sem nenhum tipo de compactação, como o PCM, o formato mais popular continua sendo o MP3 ou algo equivalente, como o AAC. Um menor uso de largura de banda por parte do áudio também permite que vídeos sejam transmitidos com maior qualidade ou que mais participantes façam parte de uma performance musical distribuída, por exemplo.

Portanto, fica claro que ainda existem muitas áreas a serem exploradas no ramo da performance musical distribuída. Neste trabalho, muitas das decisões tomadas tiveram como motivação as estruturas acessíveis por um usuário caseiro, que possuem limitações muito maiores que aquelas utilizadas em meios acadêmicos, foco de muitos outros trabalhos. A ferramenta desenvolvida apresenta flexibilidade suficientemente grande para funcionar adequadamente em ambos os ambientes e mostrou ter desempenho compatível com aplicações de finalidade semelhante. Os maiores desafios a serem enfrentados são causados por fatores externos, já que tanto a interação do processo sendo executado com o sistema operacional quanto as características da rede utilizada normalmente não estão sob o controle do usuário. Assim, o JackTripMod oferece um bom balanço entre as diversas variáveis envolvidas em uma performance musical distribuída: a latência, a largura de banda, as perdas de pacotes, o jitter e o conforto para o usuário. 
CONCLUSÃO E TRABALHOS FUTUROS 


\section{Apêndice A}

\section{CELT}

\section{A.1 Introdução}

Os codificadores de baixa latência empregados para voz usualmente possuem baixa qualidade quando utilizados em situações mais gerais que necessitem de alta fidelidade, como a codificação de músicas, por exemplo. Devido à baixa taxa de amostragem, que é usualmente de $8 \mathrm{kHz}$, as altas freqüências não podem ser reproduzidas. Por outro lado, codificadores de alta qualidade de uso geral acabam tendo um atraso algorítmico relativamente grande, não sendo adequados dependendo da aplicação desejada, como é o caso de diversos formatos populares, como o MP3 (MPEG-1 Layer III).

Um exemplo em que a necessidade de latências baixas é evidente é a ideia de realização de performances musicais pela rede. Diversos atrasos são proporcionados pelo próprio hardware, como o tempo necessário para a placa de som processar o sinal de entrada, a demora de um pacote ser preparado e enviado pela placa de rede, etc.

Nestes casos, o aumento da latência apenas por fatores algorítmicos é nitidamente indesejado. Também fica claro que há a necessidade de uma qualidade de áudio alta em uma aplicação deste tipo. Uma solução simples seria enviar as amostras independentemente como no PCM (Pulse Code Modulation ou Código por Modulação de Pulso), porém isto exige uma grande largura de banda. Assim, precisamos buscar um balanceamento entre a qualidade final do som e a latência necessária para a codificação.

A proposta do CELT (Constrained Energy Lapped Transform ou Transformada Sobreposta de Energia Restrita) [VTMM10, VTM09] é justamente essa: unir alta qualidade com baixa latência, possibilitando que novas aplicações, como as NMPs (Network Music Performance ou Performance Musical Distribuída), sejam viabilizadas.

A estrutura e visão geral do codificador já foram descritas anteriormente (página 46). A seguir, daremos uma ênfase maior aos detalhes de seu funcionamento.

\section{A.2 Divisão em Bandas}

De forma semelhante aos codecs (codificadores/decodificadores) dedicados à compactação de áudio de alta qualidade, o CELT aplica a MDCT (Modified Discrete Cosine Transform ou Transformada Discreta de Cosseno Modificada) sobre blocos de amostras, trabalhando no domínio das freqüências e explorando um pouco as características do ouvido humano, em especial a divisão do domínio espectral em regiões críticas.

Os blocos codificados reúnem 256 coeficientes cada. Como a MDCT precisa do dobro de amostras para se obter este número de coeficientes, cada janela utilizada é composta de dois blocos. A janela usada é a seguinte:

$$
w(n)=\operatorname{sen}\left[\frac{\pi}{2} \operatorname{sen}^{2}\left(\frac{\pi\left(n+\frac{1}{2}\right)}{2 L}\right)\right], \operatorname{com} L=128
$$


Esta janela possui a seguinte estrutura: 64 zeros no início, uma região de transição com 128 amostras, 128 amostras constantes no centro, outra transição com 128 amostras e, finalmente, 64 zeros ao final, resultando nas 512 amostras utilizadas para a MDCT como indicado na fig. A.1.

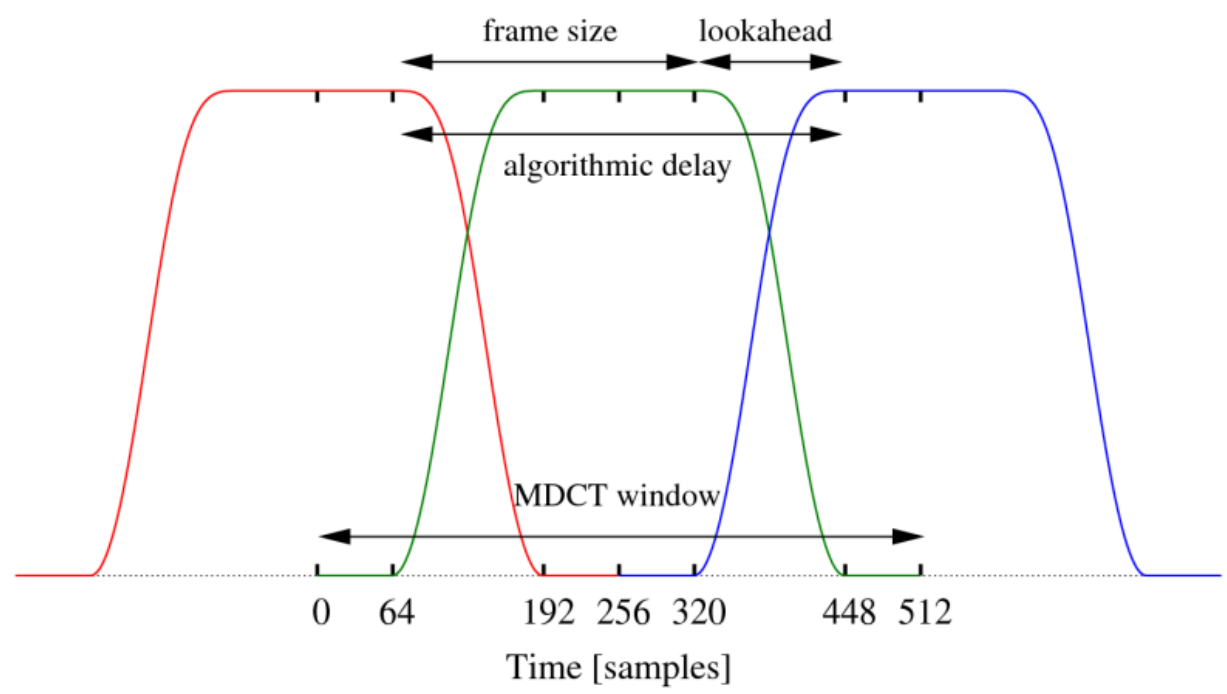

Figura A.1: Operação das janelas na MDCT [VT09]

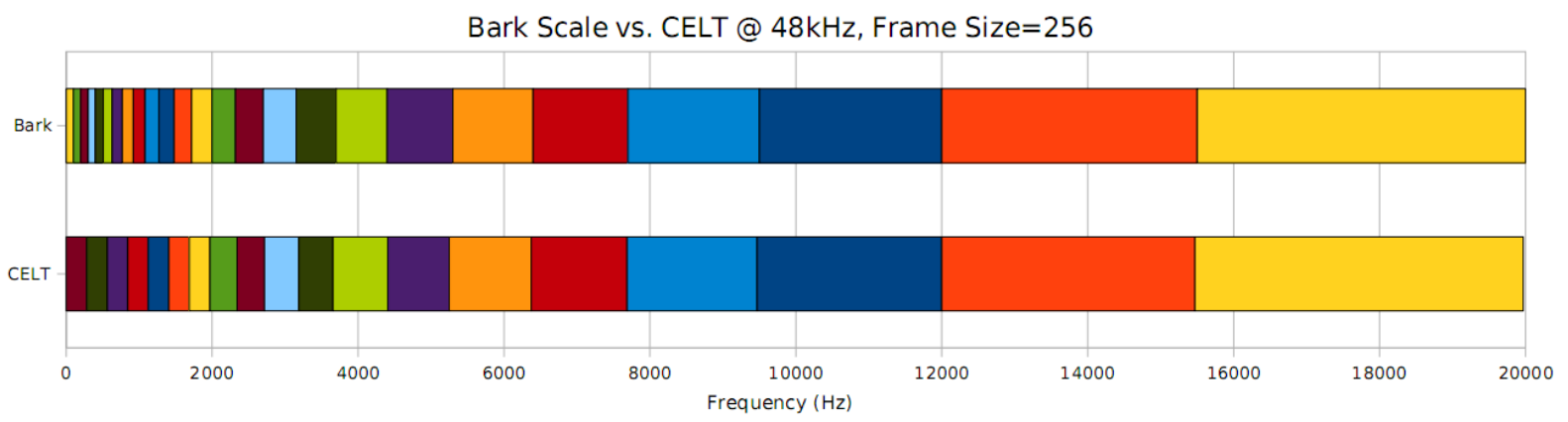

Figura A.2: Regiões críticas do ouvido e a divisão em bandas do CELT [VTO9]

Os 256 coeficientes da transformada são então divididos em bandas que tentam se aproximar ao máximo das regiões críticas do ouvido, sendo que cada banda precisa possuir no mínimo 3 coeficientes da MDCT. Isso faz com que sejam obtidos 19 bandas no total, em que a baixa resolução espectral obtida da MDCT faz com que as bandas mais graves sejam maiores do que o ideal, como pode ser observado na fig. A.2.

Em seguida, cada banda é normalizada e tem sua energia transmitida separadamente. Isso é realizado para que todas as bandas possuam uma energia que se assemelhe à do sinal original, assim, caso os bits alocados ao bloco se esgotem, o nível de detalhamento de certas bandas se tornam piores, porém um "esboço" do espectro original ainda é mantido. Assim, sendo $x$ o sinal normalizado e $z$ os coeficientes da transformada, temos que para cada banda $x=z /\|z\|$, fazendo com que $\|x\|=1$ e que $E=\|z\|^{2}$ seja a energia da banda.

Assim, uma versão quantizada de $E$ e $x$ serão transmitidas, onde $o x$ quantizado $(\tilde{x})$ é garantido que possua norma igual a 1 , fazendo com que a energia necessite ser quantizada com uma resolução suficientemente boa, pois caso contrário não é possível que o $\tilde{x}$ compense o erro de quantização obtido, já que $\|\tilde{z}\|^{2}=\tilde{E}$ não depende de $\tilde{x}$. 


\section{Quantização}

A quantização da energia de cada banda é realizada em duas etapas: primeiro o sinal é quantizado com uma resolução baixa, de $6 \mathrm{~dB}$, e em seguida o erro de quantização obtido deste processo é quantizado novamente, para que haja uma resolução final melhor.

Na primeira etapa, dois preditores são usados, tanto no domínio do tempo quanto no domínio espectral para redução da entropia. O preditor no tempo compara o bloco atual com o anterior para que apenas seja armazenada uma diferença entre eles. $O$ preditor no espectro compara bandas subseqüentes, armazenando suas diferenças. Um fator $\alpha$ é utilizado no primeiro preditor e um fator $\beta$ no segundo, cujas transformadas z são as seguintes:

$$
\begin{gathered}
P(z)=1-\alpha z^{-1} \\
Q(z)=\frac{\left(1-z^{-1}\right)}{\left(1-\beta z^{-1}\right)}
\end{gathered}
$$

Os valores de $\alpha$ e $\beta$ utilizados no CELT são $\alpha=0,8$ e $\beta=0,7$, fazendo com que o desempenho seja próximo ao do ótimo, com a vantagem de ser mais robusto a perdas de pacotes.

Ao utilizar estes preditores, a entropia pode ser reduzida em até 33 bits por bloco, sendo que 12 bits são economizados devido à predição realizada entre as bandas.

Após esta primeira etapa, um segundo quantizador é aplicado sobre o erro de predição resultante do primeiro quantizador. Esta segunda etapa provê uma melhor resolução para a energia quantizada, se ajustando conforme a frequiência a ser processada e a quantidade de bits disponíveis.

\section{A.3 Preditor de Longo Prazo}

O preditor de longo prazo (ou preditor de pitch) utilizado no CELT é utilizado opcionalmente: um modo de baixa complexidade (e menor qualidade) foi estabelecido afim de permitir o uso do codec em dispositivos de menor potência computacional, como aparelhos portáteis, por exemplo.

A motivação de se ter um preditor de longo prazo é devido à baixa resolução espectral que conseguimos ao utilizar uma MDCT com janelas tão pequenas quanto às usadas no CELT. Por exemplo, numa configuração normal, a taxa de amostragem seria de $44,1 \mathrm{kHz}$ e teríamos 256 coeficientes da transformada, o que resultaria numa resolução espectral de cerca de $172 \mathrm{~Hz}$, valor que não é suficiente para modelar os harmônicos da voz humana.

Apesar do CELT operar essencialmente no domínio da frequência, o preditor de pitch utilizado busca o período do sinal no domínio do tempo. Assim, para que seja possível modelar o período do sinal mais adequadamente, é realizada uma busca no passado do sinal decodificado afim de identificar o ponto em que haja uma maior semelhança entre o bloco atual e o passado recentemente decodificado.

Essa busca é feita nas 1024 amostras anteriores do sinal decodificado e, ao encontrar o deslocamento que tenha a maior semelhança com a janela atual, é aplicada uma MDCT e o restante das operações é realizado no domínio da frequência.

Os coeficientes $p$ obtidos são então divididos em bandas e normalizados. É calculado um ganho para cada uma das bandas, permitindo que haja um maior controle sobre cada uma delas. As bandas utilizadas são as que estão entre 0 e $8 \mathrm{kHz}$, sendo que o ganho de cada uma delas é calculado como $g_{a}=x^{\prime} p / p^{\prime} p=x^{\prime} p$. O vetor $g_{a} p$ é a projeção de $x$ em $p$, ou seja, o vetor na direção de $p$ que mais se aproxima de $x$. Além disso, $x^{\prime} p \leq 1$ pois tanto $x$ quanto $p$ são normalizados.

Como $p$ é calculado através do sinal decodificado e não do sinal de entrada, não é necessário transmitir essa informação, já que o próprio decodificador poderá realizar os mesmos procedimentos e obter o resultado desejado. Então, apenas os $g_{a}$ quantizados $\left(\tilde{g}_{a}\right)$ deverão ser transmitidos. 


\section{Quantização}

A quantização dos $g_{a}$ era feita através de quantização vetorial nas primeiras versões do CELT. Em versões mais atuais, esta idéia acabou sendo abandonada e apenas um bit para cada banda é utilizado para quantizar o ganho de $p$, podendo ele valer 0 ou 0,9 .

\section{A.4 Detalhes do Espectro}

Os detalhes do espectro são codificados através da seguinte combinação:

$$
\tilde{x}=\tilde{g}_{a} p+g_{f} y,
$$

em que $\tilde{g}_{a}$ é o ganho do pitch predito, $p$ é o vetor normalizado do pitch predito, $g_{f}$ é o ganho de $y$. Partindo da eq. (A.4), o ganho $g_{f}$ pode ser calculado da seguinte forma:

$$
\begin{aligned}
\|\tilde{x}\|^{2} & =\left\|\tilde{g}_{a} p+g_{f} y\right\|^{2}, \\
\|\tilde{x}\|^{2} & =\tilde{g}_{a}^{2}\|p\|^{2}+2 \tilde{g}_{a} g_{f} p^{\prime} y+g_{f}^{2}\|y\|^{2}, \\
1 & =\tilde{g}_{a}^{2} p^{\prime} p+2 \tilde{g}_{a} g_{f} p^{\prime} y+g_{f}^{2} y^{\prime} y, \text { pois } \tilde{x} \text { precisa ter norma } 1, \\
0 & =\left(y^{\prime} y\right) g_{f}^{2}+\left(2 \tilde{g}_{a} y^{\prime} p\right) g_{f}+\left(\tilde{g}_{a}^{2}-1\right), \text { pois } p \text { é normalizado, }
\end{aligned}
$$

Resolvendo a equação de segundo grau, temos:

$$
\begin{aligned}
\Delta & =\left(2 \tilde{g}_{a} y^{\prime} p\right)^{2}-4\left(y^{\prime} y\right)\left(\tilde{g}_{a}^{2}-1\right), \\
\Delta & =4 \tilde{g}_{a}^{2}\left(y^{\prime} p\right)^{2}+4\left(y^{\prime} y\right)\left(1-\tilde{g}_{a}^{2}\right), \\
g_{f} & =\frac{-\left(\not 2 \tilde{g}_{a} y^{\prime} p\right) \pm \sqrt{4 \tilde{g}_{a}^{2}\left(y^{\prime} p\right)^{2}+4\left(y^{\prime} y\right)\left(1-\tilde{g}_{a}^{2}\right)}}{\not 2 y^{\prime} y} \\
g_{f} & =\frac{ \pm \sqrt{\tilde{g}_{a}^{2}\left(y^{\prime} p\right)^{2}+\left(y^{\prime} y\right)\left(1-\tilde{g}_{a}^{2}\right)}-\left(\tilde{g}_{a} y^{\prime} p\right)}{y^{\prime} y} \\
g_{f} & =\frac{\sqrt{\tilde{g}_{a}^{2}\left(y^{\prime} p\right)^{2}+y^{\prime} y\left(1-\tilde{g}_{a}^{2}\right)}-\tilde{g}_{a} y^{\prime} p}{y^{\prime} y}
\end{aligned}
$$

onde $y^{\prime}$ é $y$ transposto. Assim, transmitindo apenas os ganhos do preditor de pitch e o vetor $y$ poderemos recuperar $\tilde{x}$ adequadamente.

Caso o preditor de longo prazo esteja desabilitado em certa banda (ou em todas, no caso do modo de baixa complexidade), temos que $\tilde{x}=g_{f} y$ e $g_{f}=1 / \sqrt{y^{\prime} y}$.

\section{Quantização}

O dicionário de códigos utilizado para a quantização do vetor $y$ idealmente seria baseado em uma distribuição uniforme de pontos em uma hiperesfera. Porém, não é conhecido um método de se realizar isso em uma dimensão arbitrária qualquer.

Por isso, é usado um quantizador vetorial de pirâmides, que se baseia em distribuir os pontos uniformemente em uma pirâmide, e projetamos os vetores na hiperesfera. Outra vantagem de usar este tipo de quantizador é que existem algoritmos rápidos para enumeração e busca, não sendo necessário armazenar valores em algum tipo de tabela, por exemplo.

Isto seria inviável no caso do CELT por ser um codificador em que é exigido uma grande quantidade de dicionários de código, já que cada banda pode possuir diferentes dimensões. Outro problema é que tais dicionários se tornam muito grandes, pois são exponenciais no número de dimensões, e não seriam viáveis de se armazenar em memória. 
Os vetores do dicionário de códigos com $K$ pulsos é definido da seguinte forma:

$$
C=\left\{y \in \mathbb{Z}\left|\sum_{k=1}^{K}\right| y_{i} \mid=K\right\}
$$

$O$ parâmetro $K$ pode ser tratado como a resolução do quantizador: quanto maior o $K$ mais vetores-código teremos em nosso dicionário e o erro se tornará menor.

Para encontrar o vetor $y$ desejado, minimizaremos o erro quadrático entre $r=x-g_{a} p$ e $y$ :

$$
\begin{aligned}
& y=\underset{y}{\operatorname{argmin}}\left\|r-g_{f} y\right\|^{2}, \\
& y=\underset{y}{\operatorname{argmin}}\left(r^{\prime} r-2 g_{f} r^{\prime} y+g_{f}^{2} y^{\prime} y\right), \\
& J=-2 g_{f} r^{\prime} y+g_{f}^{2} y^{\prime} y
\end{aligned}
$$

Portanto minimizaremos $J$, já que $r^{\prime} r$ é constante. Isto será feito através do algoritmo descrito a seguir:

1. Partimos de $y=(0, \ldots, 0)$ e definimos $s=\operatorname{sign}\left(r_{n}\right)$, em que $r_{n}$ é o n-ésimo elemento do vetor $r$, começando em $n=0$;

2. Fazemos $\hat{y}=y+s$ e recalculamos $J$ com $\hat{y}$. Para isso, devemos recalcular os seguintes valores:

$$
\begin{aligned}
p^{\prime} \hat{y} & =p^{\prime} y+s p_{n}, \\
r^{\prime} \hat{y} & =r^{\prime} y+s r_{n}, \\
\hat{y}^{\prime} \hat{y} & =y^{\prime} y+2 s y_{n}+1, \\
g_{f} & =\frac{\sqrt{\tilde{g}_{a}^{2}\left(p^{\prime} \hat{y}\right)^{2}+\hat{y}^{\prime} \hat{y}\left(1-\tilde{g}_{a}^{2}\right)}-\tilde{g}_{a} p^{\prime} \hat{y}}{\hat{y}^{\prime} \hat{y}}, \\
J & =-2 g_{f} r^{\prime} \hat{y}+g_{f}^{2} \hat{y}^{\prime} \hat{y} ;
\end{aligned}
$$

3. Repetimos o processo para todos os elementos de $r$, incrementando o $n$;

4. Tomamos o menor $J$ calculado nessa iteração e atualizamos y. Com isso gastamos um dos pulsos disponíveis. Repetimos todo o processo até que gastemos todos os $K$ pulsos disponíveis.

Com isso, encontramos o vetor y desejado. Agora é necessário empregarmos um método para associá-lo a um índice, que será a informação transmitida pelo codificador.

Para a enumeração dos códigos disponíveis, temos que a quantidade de vetores de dimensão $N$ com $K$ pulsos é a seguinte:

$$
V(N, K)=V(N-1, K)+V(N, K-1)+V(N-1, K-1),
$$

para $N \geq 2$ e $K \geq 2$, com $V(N, 1)=2 N$ e $V(1, K)=2$. Sabendo disso, é realizado o seguinte procedimento:

1. Seja $x=\left(x_{1}, \ldots, x_{N}\right)$;

2. Fixando $x_{1}=0$, teremos $V(N-1, K)$ combinações para o restante do vetor. Indexamos elas de $\{0, \ldots, V(N-1, K)-1\}$;

3. Fixando $x_{1}=1$, teremos $V(N-1, K-1)$ combinações e indexamos na seqüência do conjunto anterior; 
4. Fixando $x_{1}=-1$, teremos $V(N-1, K-1)$ combinações e indexamos na seqüência do conjunto anterior;

5. Repetimos o processo até atingirmos $x_{1}=K$ e $x_{1}=-K$;

6. Agora tomamos $x_{2}$, fixamos como sendo 0 e continuamos a indexar os $V(N-2, K)$ elementos restantes no conjunto. Repetimos o processo de forma semelhante à que fizemos com $x_{1}$. Apenas devemos tomar o cuidado de respeitar a restrição de que $\sum_{k=1}^{K}\left|x_{i}\right|=K$;

7. Repetimos para $x_{3}, \ldots, x_{N}$.

Ao final do processo teremos um mapeamento um para um entre os vetores códigos e os índices do conjunto calculado no procedimento.

A implementação do algoritmo de enumeração, como descrito em [Fis86] pode ser feita da seguinte forma:

\section{Codificação}

1. Definimos $b=0, i=1, k=K, n=N, V(n, 0)=1$ para $I \geq 0$ e $V(0, k)=0$ para $k \geq 1$;

2. Se $x_{i}=0$, então

$$
b=b+0
$$

Se $\left|x_{i}\right|=1$, então

$$
\begin{aligned}
b= & b+V(n-1, k) \\
& +\left[\frac{1-\operatorname{sign}\left(x_{i}\right)}{2}\right] V(n-1, k-1),
\end{aligned}
$$

Senão,

$$
\begin{aligned}
b= & b+V(n-1, k)+2 \sum_{j=1}^{\left|x_{i}\right|-1} V(n-1, k-j) \\
& +\left[\frac{1-\operatorname{sign}\left(x_{i}\right)}{2}\right] V\left(n-1, k-\left|x_{i}\right|\right)
\end{aligned}
$$

3. Faça $k=k-\left|x_{i}\right|, I=I-1$ e $i=i+1$. Se $k=0$, devolva $b$; senão, volte ao passo 2 .

\section{Decodificação}

1. Seja $b$ o inteiro devolvido pelo algoritmo de codificação. Definimos $\hat{x}=0, i=1, x b=0, k=K$, $n=N, V(n, 0)=1$ para $I \geq 0$ e $V(0, k)=0$ para $k \geq 1$;

2. Se $b=x b$, faça $\hat{x}_{i}=0$. Vá para o passo 6 ;

3. Se $b<x b+V(n-1, k)$, faça $\hat{x}_{i}=0$ e vá para o passo 5; Senão, $x b=x b+V(n-1, k)$ e $j=1$.

4. Se $b<x b+2 V(n-1, k-j)$, então

$$
\hat{x}_{i}= \begin{cases}j & \text { se } x b \leq b<x b+V(n-1, k-j) \\ -j & \text { se } b \geq x b+V(n-1, k-j)\end{cases}
$$

Senão, $x b=x b+2 V(n-1, k-j), j=j+1$ e vá para 4 ; 
5. Faça $k=k-\left|\hat{x}_{i}\right|, I=I-1, i=i+1$. Se $k>0$ vá para 2 ;

6. Se $k>0$, faça $\hat{x}_{N}=k-\left|\hat{x}_{i}\right|$. Devolva $\hat{x}$, o vetor código associado ao inteiro $b$.

Com os algoritmos descritos nesta seção, podemos quantizar e enumerar o vetor $y$ de forma eficiente.

\section{A.5 Resultados}

Discutiremos brevemente os testes objetivos e subjetivos [VT09, VTMM10, VTM09] realizados pelos criadores do formato comparando o CELT com outros codecs com o mesmo tipo de proposta, como o ULD (Fraunhofer Ultra Low Delay ou Fraunhofer Ultra Baixa Latência), o padrão G.722.1C e o AAC-LD (Advanced Audio Coding - Low Delay ou Codificação Avançada de Áudio - Baixa Latência), além de uma comparação com o próprio formato MP3, mesmo este não competindo diretamente com o CELT, devido ao maior atraso algorítmico.

Os dois modos de operação do CELT foram utilizados em comparações distintas. O modo de baixa complexidade, com o preditor de longo prazo desabilitado foi comparado com o ULD e o G.722.1C. Já o modo usual, foi comparado com o AAC-LD, o G.722.1C e o MP3.

Por mais que a proposta dos codecs de baixa latência seja a mesma, diversas características são diferentes entre eles:

- O AAC-LD possui um atraso mínimo de $20 \mathrm{~ms}$, porém, na implementação testada o atraso mínimo era de $34,8 \mathrm{~ms}$, valor bastante superior ao obtido pelo CELT;

- O G.722.1C tem uma latência de 40 ms, sendo também limitado na taxa de amostragem (máximo de $32 \mathrm{kHz}$ ) e na taxa de bits (máximo de 48 kbps);

- O ULD tem um atraso de 5,3 ms, sendo o mais próximo do alcançado pelo CELT, porém a taxa de bits recomendada pelo padrão ULD é de 96 kbps, enquanto o CELT recomenda 48 kbps.

- O MP3 tem um atraso algorítmico de mais de 100 ms.

O teste subjetivo foi realizado usando a metodologia MUSHRA (MUltiple Stimulus with Hidden Reference and Anchor ou Estímulo Múltiplo com Referência e Âncora Escondida) e os resultados podem ser vistos nas figs. A.3 e A.4.

Na fig. A.3, é utilizado o modo de baixa complexidade do CELT versão 0.5 , onde pode ser observado que sua qualidade foi maior que a do ULD com uma latência ligeiramente maior que a deste, porém com uma taxa de bits muito menor (96 kbps para o ULD e 64 kbps para o CELT). Fazendo com que a taxa de bits dos dois codecs se igualasse e diminuindo a latência do CELT para um pouco menos que a do ULD, o CELT novamente demonstra ser superior. O G.722.1C possui a menor qualidade dos codecs deste teste já que sua taxa de bits é limitada a $48 \mathrm{kbps}$.

Na fig. A.4, o CELT versão 0.3.2 é comparado com outros codificadores se aproveitando de seu preditor de pitch. A taxa de bits utilizada foi de $48 \mathrm{kbps}$ para todos os envolvidos e mostra que o CELT obteve a melhor qualidade subjetiva dentre os codificadores testados.

\section{A.6 Conclusão}

O codificador estudado neste trabalho mostrou ser possível aliar uma boa qualidade de áudio com baixa latência, viabilizando aplicações como a performance musical via rede. Comparado com seus principais competidores, o CELT se mostrou superior, obtendo uma melhor relação entre qualidade, taxa de bits e latência.

Também é importante ressaltar que o formato em si é bastante versátil, cobrindo uma grande variedade de taxas de bits, taxas de amostragem e tamanhos de bloco (diretamente associados ao atraso algorítmico), além de ser um formato aberto com código-fonte disponível na internet. 


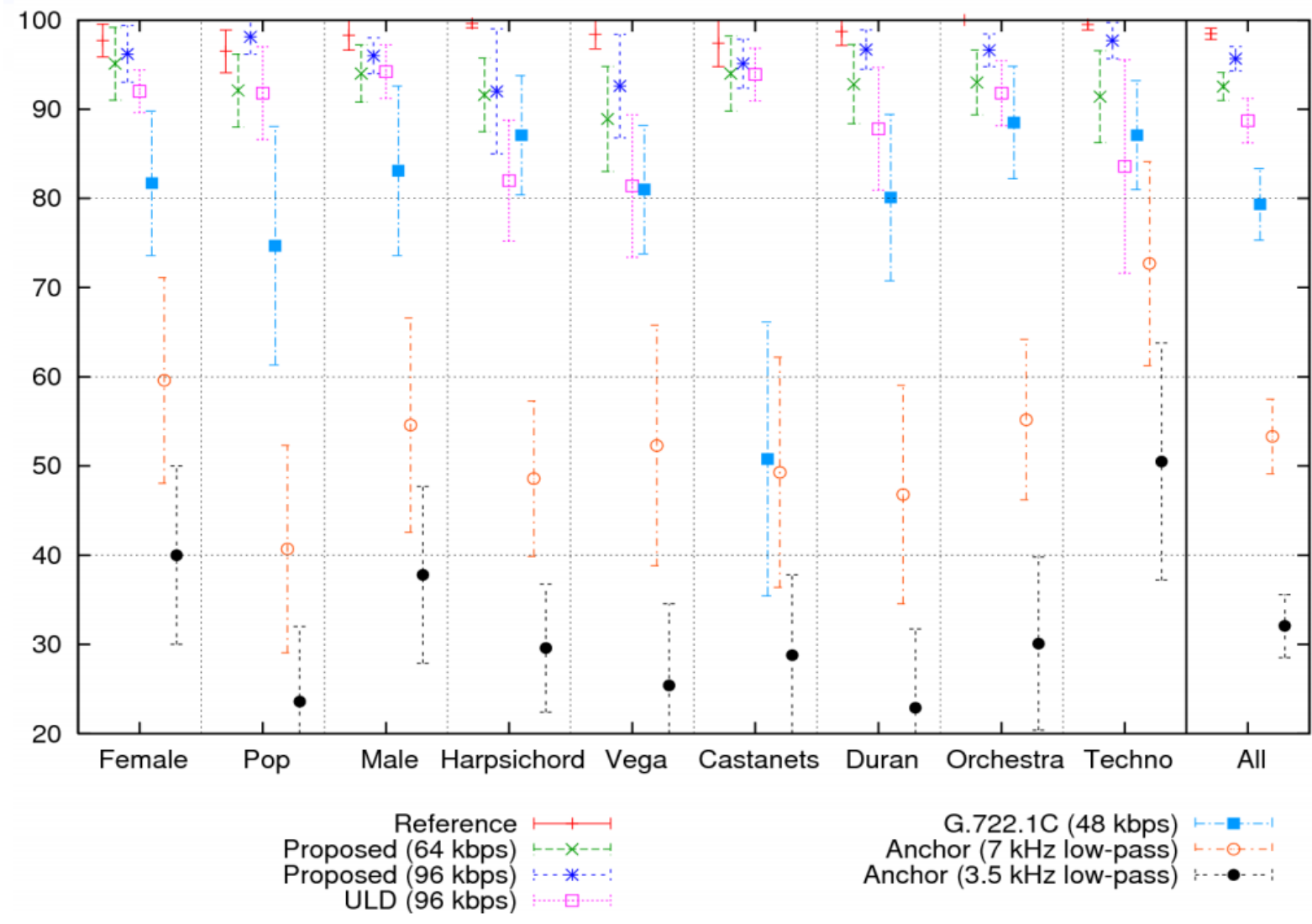

Figura A.3: Teste realizado sem o preditor de longo prazo [VT09]

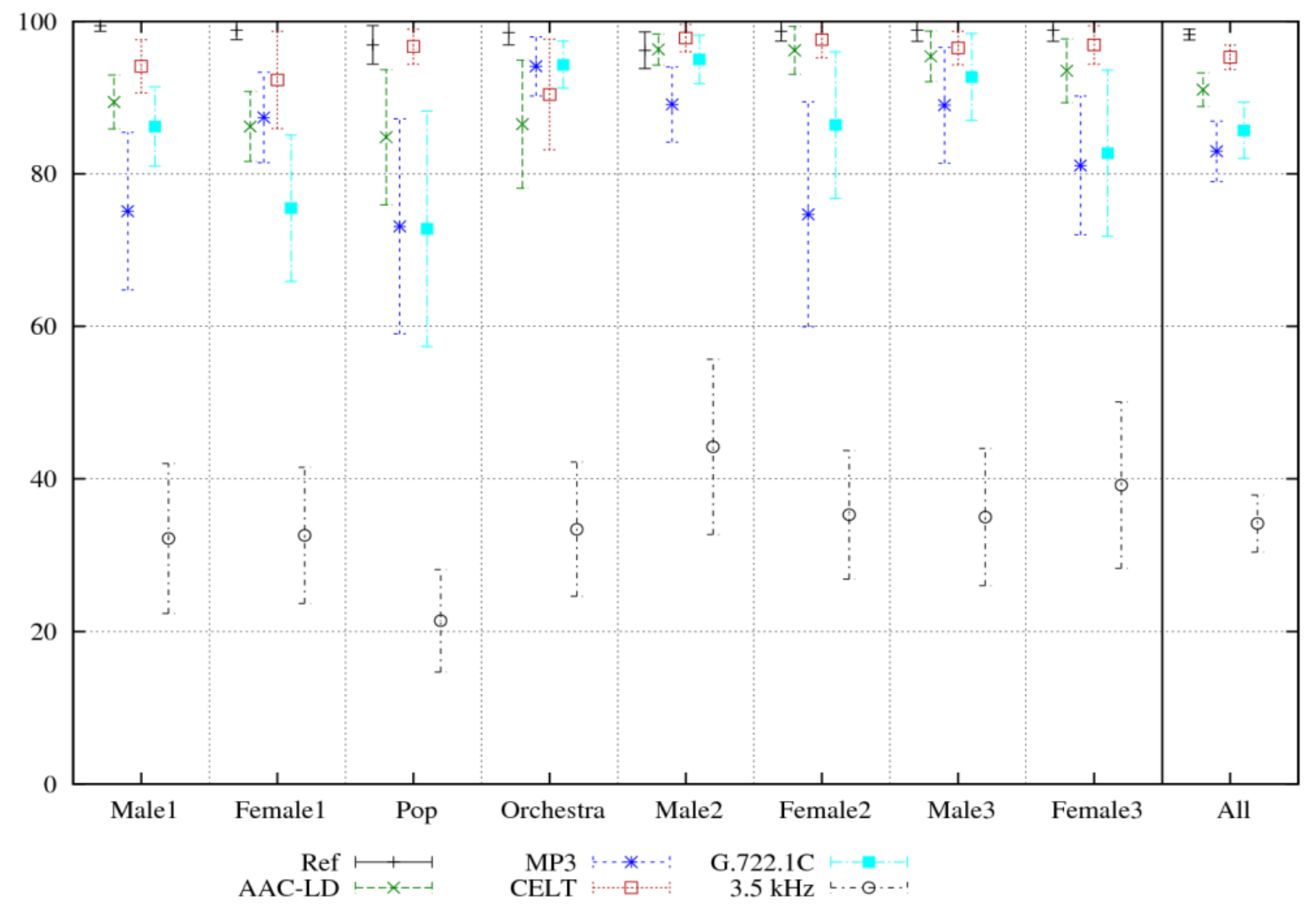

Figura A.4: Teste realizado com o preditor de longo prazo a 64 kbps [VTO9] 
Além disso, a qualidade atingida por este projeto foi recompensada com a sua escolha como base da implementação do OPUS, padrão da Internet [VVT12] que propõe um formato único para todo tipo de aplicação de áudio utilizada atualmente, desde transmissão de voz até sinais de alta fidelidade. Este objetivo foi atingido através da mescla do próprio CELT com o codificador de sinais de voz SILK, utilizado no Skype. Por se tratar de um formato recomendado pela IETF (Internet Engineering Task Force ou Força Tarefa de Engenharia da Internet), a tendência é de que sua aceitação na indústria de softwares seja cada vez maior, possibilitando que mais esforços sejam dedicados ao seu desenvolvimento futuro. 
APÊNDICE A 


\section{Referências Bibliográficas}

[AJ90] Anders Askenfelt e Erik $V$ Jansson. From touch to string vibrations. i: Timing in the grand piano action. The Journal of the Acoustical Society of America, 88:52, 1990.

[AJ07] F. Audet e C. Jennings. Network Address Translation (NAT) Behavioral Requirements for Unicast UDP. RFC 4787 (Best Current Practice), Janeiro 2007.

[Ass97] ITU Radiocommunication Assembly. Methods for the subjective assessment of small impairments in audio systems including multichannel sound systems. Relatório técnico, International Telecommunication Union, 1997. ITU-R recommendation BS.1116-1.

[Ass01] ITU Radiocommunication Assembly. Method for objective measurements of perceived audio quality. Relatório técnico, International Telecommunication Union, 2001. ITU-R recommendationc BS.1387-1.

[Ass03] ITU Radiocommunication Assembly. Method for the subjective assessment of intermediate quality levels of coding systems. Relatório técnico, International Telecommunication Union, 2003. ITU-R recommendation BS.1534-1.

$\left[\mathrm{BMM}^{+}\right.$08] D. Bonfiglio, M. Mellia, M. Meo, N. Ritacca e D. Rossi. Tracking down Skype traffic. Em INFOCOM 2008. The 27th Conference on Computer Communications. IEEE, páginas 261-265. IEEE, 2008.

[BS04] S.A. Baset e H. Schulzrinne. An analysis of the Skype peer-to-peer internet telephony protocol. arXiv preprint cs/0412017, 2004.

[C $\mathrm{C}^{+99]}$ International Electrotechnical Commission et al. Audio recording - compact disc digital audio system, 1999.

$\left[\mathrm{CAM}^{+} 11\right]$ Juliana Azevedo de Souza Caribé, Rose Mary Maduro Camboim de Azevedo, Ewerton Madruga, Luciana Alves de Almeida Carvalho, Luiz Carlos Monteiro e Alfredo Carlos Orphão Lobo. Programa de análise de produtos : relatório sobre análise em provedores de banda larga (Rio de Janeiro, São Paulo e Belo Horizonte). Relatório técnico, Inmetro, Instituto Nacional de Metrologia, Qualidade e Tecnologia, 2011.

[Car09] A. Carôt. Musical Telepresence: A Comprehensive Analysis Towards New Cognitive and Technical Approaches. Tese de Doutorado, Universität zu Lübeck, 2009.

[Car10] A. Carôt. Low latency audio streaming for internet-based musical interaction. Streaming Media Architectures: Techniques and Applications: Recent Advances, página 362, 2010.

[CC10] J.P. Cáceres e C. Chafe. JackTrip: Under the hood of an engine for network audio. Journal of New Music Research, 38(3), 2010.

$\left[\mathrm{CHI}^{+}\right.$08] J.P. Cáceres, R. Hamilton, D. Iyer, C. Chafe e G. Wang. To the edge with China: Explorations in network performance. Em ARTECH 2008: Proceedings of the 4th International Conference on Digital Arts, páginas 61-66, 2008. 
[CHW09] A. Carôt, T. Hohn e C. Werner. Netjack - remote music collaboration with electronic sequencers on the internet. Em Proceedings of the Linux Audio Conference, 2009.

[CK13] S. Cheshire e M. Krochmal. NAT Port Mapping Protocol (NAT-PMP). Internet-Draft draft-cheshire-nat-pmp-07.txt, IETF Secretariat, Janeiro 2013.

[Coe11] J. M. Coelho. A música do futuro. Revista FAPESP, 190, Dezembro 2011.

[Coe12] J. M. Coelho. Concertos em alta conexão. O Estado de São Paulo, Março 2012.

[CR08] J.P. Cáceres e A.B. Renaud. Playing the network: the use of time delays as musical devices. Em Proceedings of International Computer Music Conference, Belfast, Northern Ireland, páginas 244-250, 2008.

[CW07] A. Carôt e C. Werner. Network music performance-problems, approaches and perspectives. Em Proceedings of the "Music in the Global Village"-Conference, Budapest, Hungary, 2007.

[CW08] A. Carôt e C. Werner. Distributed Network Music Workshop with Soundjack. Proceedings of the 25th Tonmeistertagung, Leipzig, Germany, 2008.

[CWW02] C. Chafe, S. Wilson e D. Walling. Physical model synthesis with application to Internet acoustics. Em IEEE International Conference on Acoustics Speech and Signal Processing, volume 4, páginas 4056-4059, 2002.

$\left[\mathrm{dLFdJ}^{+}\right.$08] A.A. de Lima, F.P. Freeland, R.A. de Jesus, B.C. Bispo, L.W.P. Biscainho, S.L. Netto, A. Said, A. Kalker, R. Schafer, B. Lee et al. On the quality assessment of sound signals. Em Circuits and Systems, 2008. ISCAS 2008. IEEE International Symposium on, páginas 416-419. IEEE, 2008.

[EVHU ${ }^{+}$08] Jan Erik Voldhaug, Erik Hellerud, Astrid Undheim, Erling Austreim, Peter U Svensson e Peder J Emstad. Influence of sender parameters and network architecture on perceived audio quality. Acta Acustica united with Acustica, 94(1):1-11, 2008.

[Fis86] T. Fischer. A pyramid vector quantizer. IEEE Transactions on Information Theory, 32(4):568-583, 1986.

[For10] UPnP Forum. Internet gateway device (IGD) v 2.0. http://upnp.org/specs/gw/igd2/, Dezembro 2010. Acessado em janeiro de 2013.

[FSK05] Bryan Ford, Pyda Srisuresh e Dan Kegel. Peer-to-peer communication across network address translators. Em Proceedings of the annual conference on USENIX Annual Technical Conference, ATEC '05, páginas 13-13, Berkeley, CA, USA, 2005. USENIX Association.

[GD05] S. Guha e N. Daswani. An experimental study of the Skype peer-to-peer VolP system. 2005.

[GL98] S. Gresham-Lancaster. The aesthetics and history of The Hub: The effects of changing technology on network computer music. Leonardo Music Journal, páginas 39-44, 1998.

$\left[\mathrm{H}^{+} 05\right]$ Stephen Hemminger et al. Network emulation with netem. Em linux.conf.au, páginas 18-23, 2005.

[Hec02] E. Hecht. Optics. Addison-Wesley, 2002.

[HSV12] Erik Hellerud, Peter Svensson e Jan Erik Voldhaug. Evaluation of packet loss distortion in audio signals. Em AES Convention, volume 120, Maio 2012. 
[KBS08] W. Kho, S.A. Baset e H. Schulzrinne. Skype relay calls: Measurements and experiments. Em INFOCOM Workshops 2008, IEEE, páginas 1-6. IEEE, 2008.

[KI98] Fabio Kon e Fernando lazzetta. Internet music: Dream or (virtual) reality. Em Proceedings of the 5th Brazilian Symposium on Computer Music, páginas 69-81, 1998.

[KOGC97] D. Konstantas, Y. Orlarey, S. Gibbs e O. Carbonel. Distributed musical rehearsal. Em Proceedings of the 1997 International Computer Music Conference, páginas 279-282, 1997.

[Kon12] Kazuhiro Kondo. On the use of objective quality measures to estimate watermarked audio quality. Em Intelligent Information Hiding and Multimedia Signal Processing (IIH-MSP), 2012 Eighth International Conference on, páginas 126-129. IEEE, 2012.

[KS83] K. Karplus e A. Strong. Digital synthesis of plucked-string and drum timbres. Computer Music Journal, 7(2):43-55, 1983.

[LK04] Nelson Posse Lago e Fabio Kon. The quest for low latency. Em Proceedings of the International Computer Music Conference, páginas 33-36, 2004.

[LSG ${ }^{+}$04] M. Lutzky, G. Schuller, M. Gayer, U. Krämer e S. Wabnik. A guideline to audio codec delay. Em AES 116th convention, Berlin, Germany, páginas 8-11, 2004.

[MKB12a] Ewerton L. Madruga, Milton K. Kashiwakura e Dirceu Baraviera. Residential broadband services: Assessing quality from the user's perspective. Em // Workshop on Broadband Access Networks (WRA'12), 2012.

[MKB12b] Ewerton Longoni Madruga, Milton Kaoru Kashiwakura e Dirceu Baraviera. Measuring nationwide residential broadband services. Em Innovations in Information Technology (IIT), 2012 International Conference on, páginas 89-94. IEEE, 2012.

[MKC08] A. Müller, A. Klenk e G. Carle. On the applicability of knowledge based NAT-traversal for home networks. NETWORKING 2008 Ad Hoc and Sensor Networks, Wireless Networks, Next Generation Internet, páginas 264-275, 2008.

[ML10] D. MacDonald e B. Lowekamp. NAT Behavior Discovery Using Session Traversal Utilities for NAT (STUN). RFC 5780 (Experimental), Maio 2010.

[MMR10] R. Mahy, P. Matthews e J. Rosenberg. Traversal Using Relays around NAT (TURN): Relay Extensions to Session Traversal Utilities for NAT (STUN). RFC 5766 (Proposed Standard), Abril 2010.

[MS09] Eugene S. Myakotnykh e U. Peter Svensson. Towards a computational quality model for IP-based audio. Em Quality of Multimedia Experience, 2009. QoMEx 2009. International Workshop on, páginas 110-115. IEEE, 2009.

[MU01] P. Mehta e S. Udani. Voice over IP. Potentials, IEEE, 20(4):36-40, 2001.

[Net11] NetConcert MOBILE / SARC. http://www.eca.usp.br/mobile/portal/index.php?q=node/ 438, Junho 2011. Acessado em novembro de 2012.

[Net12] Net Concert / Concerto em Rede. http://www.eca.usp.br/mobile/portal/index.php?q= node/239, Março 2012. Acessado em novembro de 2012.

[NR09] Lucas Nussbaum e Olivier Richard. A comparative study of network link emulators. Em Proceedings of the 2009 Spring Simulation Multiconference, página 85. Society for Computer Simulation International, 2009. 
[Oza12] Seiji Ozawa. Encyclopaedia Britannica online, 2012. http://www.britannica.com/ EBchecked/topic/437159/Seiji-Ozawa. Acessado em dezembro de 2012.

[Per99] A. Percy. Understanding latency in IP telephony. Brooktrout Technology, Needham, MA, 1999.

[PSR ${ }^{+}$08] David Palomar, Ronan Skehill, Ian Rice, Dorel Picovici e Sean Mc Grath. Objective assessment of audio quality. Em Signals and Systems Conference, 208.(ISSC 2008). IET Irish, páginas 37-42. IET, 2008.

[Puc07] M. Puckette. The theory and technique of electronic music. World Scientific Publishing Company Incorporated, 2007.

[RCR07] A. B. Renaud, A. Carôt e P. Rebelo. Networked music performance: State of the art. Em Proceedings of the AES 30th International Conference, 2007.

[RMK+96] Y. Rekhter, B. Moskowitz, D. Karrenberg, G. J. de Groot e E. Lear. Address Allocation for Private Internets. RFC 1918 (Best Current Practice), Fevereiro 1996.

[RMMW08] J. Rosenberg, R. Mahy, P. Matthews e D. Wing. Session Traversal Utilities for NAT (STUN). RFC 5389 (Proposed Standard), Outubro 2008.

[RNPa] Rede Nacional de Ensino e Pesquisa - A Rede. http://www.rnp.br/ipe/. Acessado em novembro de 2012.

[RNPb] Rede Nacional de Ensino e Pesquisa - Mapa do Backbone. http://www.rnp.br/backbone/ index.php. Acessado em novembro de 2012.

[Ros10] J. Rosenberg. Interactive Connectivity Establishment (ICE): A Protocol for Network Address Translator (NAT) Traversal for Offer/Answer Protocols. RFC 5245 (Proposed Standard), Abril 2010. Updated by RFC 6336.

[RT12] L.S. Roça e M. Tramontano. Entornos híbridos: som, espaço e simultaneidade. Seminário Música Ciência Tecnologia, 1(4), 2012.

[RWHM03] J. Rosenberg, J. Weinberger, C. Huitema e R. Mahy. STUN - Simple Traversal of User Datagram Protocol (UDP) Through Network Address Translators (NATs). RFC 3489 (Proposed Standard), Março 2003. Obsoleted by RFC 5389.

[SA85] M. Schroeder e B. Atal. Code-excited linear prediction(CELP): High-quality speech at very low bit rates. Em Acoustics, Speech, and Signal Processing, IEEE International Conference on ICASSP '85., volume 10, páginas 937 - 940, apr 1985.

[SA11a] P. Saint-Andre. Extensible Messaging and Presence Protocol (XMPP): Core. RFC 6120 (Proposed Standard), Março 2011.

[SA11b] P. Saint-Andre. Extensible Messaging and Presence Protocol (XMPP): Instant Messaging and Presence. RFC 6121 (Proposed Standard), Março 2011.

[Sam12] J. L. Sampaio. Músicos fazem hoje ensaio pela internet. O Estado de São Paulo, Maio 2012.

[SC02] N. Schuett e C. Chafe. The Effects of Latency on Ensemble Performance. 2002.

[Sec03] ITU Telecommunication Standardization Sector. Perceptual evaluation of speech quality (PESQ): An objective method for end-to-end speech quality assessment of narrow-band telephone networks and speech codecs. Relatório técnico, International Telecommunication Union, 2003. ITU-T recommendation P.862. 
[SFK08] P. Srisuresh, B. Ford e D. Kegel. State of Peer-to-Peer (P2P) Communication across Network Address Translators (NATs). RFC 5128 (Informational), Março 2008.

[Sil12] F.A.F. Silva. Música telemática latência, atitude composicional e presentidade. Seminário Música Ciência Tecnologia, 1(4), 2012.

[Sky] Skype. How much bandwidth does Skype need? https://support.skype.com/en/faq/ FA1417/how-much-bandwidth-does-skype-need. Acessado em novembro de 2012.

[SW06] B. Sat e B.W. Wah. Analysis and evaluation of the Skype and Google-Talk VolP systems. Em Multimedia and Expo, 2006 IEEE International Conference on, páginas 2153-2156. IEEE, 2006.

[Tan99] A. Tanaka. Network Audio Performance and Installation. Em Proc. Intnl Computer Music Conf, 1999.

[TW10] A.S. Tanenbaum e D.J. Wetherall. Computer Networks. Prentice Hall, quinta edição, 2010.

[UVC] Ultra-videoconferencing. http://www.cim.mcgill.ca/sre/projects/rtnm/. Acessado em novembro de 2012

[VHS07] Jan Erik Voldhaug, Erik Hellerud e Ulf Peter Svensson. How much is too much?-on the acceptability of packet loss distorted audio. Em Signal Processing and Communications, 2007. ICSPC 2007. IEEE International Conference on, páginas 536-539. IEEE, 2007.

[VSMH02] U. Varshney, A. Snow, M. McGivern e C. Howard. Voice over IP. Communications of the ACM, 45(1):89-96, 2002.

[VT09] J.M. Valin e T.B. Terriberry. CELT: A Low-latency, High-quality Audio Codec. Em linux.conf.au 2009, 2009. Slides: http://www.celt-codec.org/presentations/misc/lcacelt.pdf.

[VTM09] J.M. Valin, T.B. Terriberry e G. Maxwell. A Full Bandwidth Audio Codec with Low Complexity and Very Low Delay. Em 17th European Signal Processing Conference, 2009.

[VTMM10] J.M. Valin, T.B. Terriberry, C. Montgomery e G. Maxwell. A high-quality speech and audio codec with less than 10-ms delay. Audio, Speech, and Language Processing, IEEE Transactions on, 18(1):58 -67, jan. 2010.

[VVT12] J.M. Valin, K. Vos e T. Terriberry. Definition of the Opus Audio Codec. RFC 6716 (Proposed Standard), Setembro 2012.

[WCHL09] C.C. Wu, K.T. Chen, C.Y. Huang e C.L. Lei. An empirical evaluation of VolP playout buffer dimensioning in Skype, Google talk, and MSN Messenger. Em Proceedings of the 18th international workshop on Network and operating systems support for digital audio and video, páginas 97-102. ACM, 2009.

[WCRM04] W. Woszczyk, J. Cooperstock, J. Roston e W. Martens. Environment for immersive multisensory communication of music using broadband networks. Em In: 23. Tonmeistertagung VDT International Audio Convention, 2004.

[WCZ04] Matthew Wright, Ryan J. Cassidy e Michael F. Zbyszynski. Audio and gesture latency measurements on Linux and OSX. Em Proceedings of the ICMC, páginas 423-429, 2004.

[Wor] The World Opera. http://www.theworldopera.org/. Acessado em novembro de 2012.

[WP11] M. Westerlund e C. Perkins. IANA Registry for Interactive Connectivity Establishment (ICE) Options. RFC 6336 (Proposed Standard), Julho 2011. 
[WSR10] Yonghao Wang, Ryan Stables e Joshua Reiss. Audio latency measurement for desktop operating systems with onboard soundcards. Em AES Convention, volume 128, Maio 2010.

[You01] J.P. Young. Using the Web for Live Interactive Music. Em Proceedings of the 2001 International Computer Music Conference, páginas 302-305, 2001.

[YXY09] Yang Yue, Xie Xiang e Wei Yaodu. A novel objective method for evaluating the quality of streaming audio. Em Broadband Network \& Multimedia Technology, 2009. IC-BNMT'09. 2nd IEEE International Conference on, páginas 555-559. IEEE, 2009. 